\title{
Specific limits and emerging diversity patterns in East African populations of laminate-toothed rats, genus Otomys (Muridae: Murinae: Otomyini): Revision of the Otomys typus complex
}

\author{
PETER J. TAYLOR ${ }^{1,7}$, LEONID A. LAVRENCHENKO ${ }^{2}$, \\ MICHAEL D. CARLETON ${ }^{3}$, ERIK VERHEYEN ${ }^{4}$,
} NIGEL C. BENNETT ${ }^{5}$, CAREL J. OOSTHUIZEN ${ }^{6} \&$ SARITA MAREE $^{5,6}$

${ }^{1}$ Durban Natural Science Museum, P. O. Box 4085, Durban, 4000, Department of Ecology \& Resource Management, University of Venda, Private Bag X5050, Thohoyandou, 0950, and School of Biological and Conservation Sciences,

University of KwaZulu Natal, South Africa. E-mail: Peter.Taylor@univen.ac.za

${ }^{2}$ Severtsov Institute of Ecology and Evolution, Russian Academy of Sciences, Leninsky pr., 33, Moscow, 119071, Russia.

E-mail: lavrenchenko@sevin.ru

${ }^{3}$ Department of Vertebrate Zoology, National Museum of Natural History, Smithsonian Institution, Washington,

D.C. 20560-0108, USA.E-mail: carletonm@si.edu

${ }^{4}$ Vertebrate Department, Royal Belgian Institute of Natural Sciences, Vautiersstraat 29, 1000 Brussels, Belgium.

E-mail:erik.verheyen@naturalsciences.be

${ }^{5}$ Mammal Research Institute, Department of Zoology and Entomology, University of Pretoria, Pretoria, 0002, South Africa.

E-mail: smaree@zoology.up.ac.za

${ }^{6}$ Molecular Ecology and Evolution Programme, Department of Genetics, University of Pretoria, Pretoria, 0002, South Africa ${ }^{7}$ Corresponding author 


\section{Abstract}

We combined evidence from biogeography, craniodental traits, linear and geometric morphometrics (233 skulls), cytogenetics (karyotypes of 18 individuals) and mitochondrial DNA sequences (44 cytochrome $b$ and 21 12S rRNA sequences) to test species limits within Otomys typus s.l. (Muridae: Murinae: Otomyini), a complex that is patchily distributed across alpine zones of Ethiopia and East Africa. Our results confirm the specific validity of $O$. dartmouthi, O. jacksoni, O. orestes, and $O$. uzungwensis, forms recently removed from synonymy under typus s.l.; support elevation of four other alpine forms to species $(O$. fortior, $O$. helleri, $O$. thomasi, and $O$. zinki); identify three additional new species $(O$. cheesmani $\mathbf{s p}$. nov., $O$. simiensis sp. nov., $O$. yaldeni sp. nov.); and enable redefinition of $O$. typus s.s. as a species restricted to certain mountains west of the Great Rift Valley in Ethiopia (Simien and Guna Mountains in the north, extending to the highlands of the western rim of the Rift Valley). Phylogenetic interpretation of the cytochrome $b$ data clearly demonstrates that the alpine morphotype once united under $O$. typus s.l. has originated independently at high elevations on several mountain ranges in eastern and northeastern Africa; although generally adapted to high-elevation vegetation, such alpine species are ecologically segregated from one another. Patterns of morphometric, genetic, and ecological differentiation among populations once misassigned to nominal $O$. tropicalis and $O$. typus more parsimoniously reflect regional cladogenesis along elevational gradients, rather than multiple, successive colonization by different ancestral forms from southern Africa as earlier supposed. Although incomplete and preliminary, information gathered for $O$. tropicalis indicates that it too is a species composite; several lines of research are discussed to redress its polyphyletic content. Our results, together with other recent taxonomic studies of Otomys, appreciably elevate the level of endemism within eastern Africa and underscore the significance of Africa's eastern highlands to the continental diversification of Otomyini.

Key words: Otomys, geometric morphometrics, cytochrome $b, 12 \mathrm{~S}$ rRNA, microendemism, speciation, Afromontane

\section{Résumé}

Nous avons combiné un ensemble de données, biogéographiques craniodentaires, morphométriques (linéaires et géométriques; 233 crânes), cytogénétiques (caryotypes de 18 individus) et moléculaires (ADN mitochondrial: 44 séquences de cytochrome $b$ et 21 séquences de 12 rRNA) afin d'évaluer les délimitations d'espèces au sein d'Otomys typus s.1. (Muridae: Murinae: Otomyini), un complexe d'espèces distribué à travers les zones alpestres de l'Éthiopie et d'Afrique de l'Est. Nos résultats 1) confirment le statut spécifique d'O. dartmouthi, O. jacksoni, O. orestes et $O$. uzungwensis, des formes dont la synonymie avec typus s.l. a récemment été infirmée, 2) soutiennent l'élévation au statut d'espèce de quatre autres formes alpestres $(O$. fortior, $O$. helleri, $O$. thomasi et $O$. zinki), 3) permettent d'identifier trois nouvelles espèces supplémentaires (O. cheesmani sp. nov., $O$. simiensis $\mathbf{s p . ~ n o v . , ~ O . ~ y a l d e n i ~} \mathbf{s p . ~ n o v . ) , ~ e t ~} 4$ ) nous permettent de redéfinir O. typus s.s. comme une espèce restreinte à certaines montagnes à l'ouest de la Vallée du Rift en Éthiopie (les montagnes Simien et Guna au nord, s'étendant aux pays montagneux du bord occidental de la vallée du Rift). L'interprétation phylogénétique des séquences de cytochrome $b$ démontre clairement que la forme alpestre autrefois incluse dans $O$. typus s.l. est apparue de façon indépendante à de hautes altitudes sur plusieurs massifs montagneux en Afrique de l'Est et du Nord-Est. Bien que généralement adaptées à la végétation de haute altitude, de telles espèces alpestres sont écologiquement distinctes les unes des autres. Les différentiations morphométrique, génétique et écologique au sein des populations regroupées de façon incorrecte sous les noms $O$. tropicalis et $O$. typus reflètent plus parcimonieusement une diversification régionale suivant des gradients altitudinaux, plutôt qu'unecolonisation multiple, successive par différentes formes ancestrales d'Afrique du Sud, comme supposé antérieurement. Bien qu'incomplètes et préliminaires, les données obtenues pour $O$. tropicalis indiquent qu'il constitue aussi un complexe d'espèces. Plusieurs lignes de recherche sont envisagées afin de réévaluer son statut polyphylétique. Nos résultats, ajoutés à d'autres études taxinomiques récentes d'Otomys, élèvent sensiblement le niveau d'endémisme en l'Afrique de l'Est et soulignent l'importancedes hautes terres de l'est de l'Afrique dans la diversification continentale des Otomyini. 


\section{Introduction}

Laminate-toothed or "vlei" rats (Tribe Otomyini) are distributed over much of sub-Saharan Africa, where they constitute a small but morphologically distinctive radiation of murine rodents within the continent's savannas and highlands (Bohmann 1952; Carleton \& Musser 1984; Taylor et al. 2004a; b; 2009a; b). Although southern Africa circumscribes the area of origin of the tribe (Pocock 1976; 1987; Denys 1989; 2003; Senegas \& Avery 1998; Senegas 2001), eastern Africa, with its spectacular montane and alpine landscapes, is only beginning to be appreciated for its important role in diversification and endemism of otomyine rodents and other vertebrate taxa (Bowie et al. 2004; 2006; Carleton \& Stanley 2005; Carleton \& Byrne 2006; Carleton et al. 2006; Fahr et al. 2002; Kerbis Peterhans et al. 1998; Kerbis Peterhans \& Hutterer, in press; Stanley \& Hutterer 2000; Stanley \& Olson 2005; Stanley et al. 2005; Huhndorf et al. 2007; Taylor et al. 2009a; Van der Straeten \& Kerbis Peterhans 1999). Musser \& Carleton (2005:1524) emphasized the need for renewed revision of Otomys F. Cuvier (1824) populations that inhabit the rugged East African mountain ranges and volcanoes, and recent studies have elevated several species formerly obscured in synonymy under $O$. denti Thomas (1906), O. tropicalis (1902), or O. typus Heuglin, (1877) (Carleton \& Byrne 2006; Taylor et al. 2009a) and identified unnamed cytochrome $b$ (cyt $b$ ) lineages from the Nyika Plateau, Malawi, and the Eastern Arc Mountains, Tanzania (Taylor et al. 2009a). The present investigation contributes new information that bears on the status of additional taxa placed within the $O$. typus complex.

Bohmann's (1952) classic revision of Otomys established the polytypic arrangement of O. typus (Heuglin, 1877) that has prevailed in systematic treatises over the latter 1900s (e.g., Misonne 1974; Honacki et al. 1982; Corbet \& Hill 1991; Musser \& Carleton 1993; see Table 1). Whereas previous authors had restricted O. typus to Ethiopia (Dollman 1915; Allen 1939; Ellerman 1941), Bohmann dramatically expanded its morphological and geographic definition to embrace 11 subspecies that range over disjunct alpine settings in eastern Africa (Fig. 1a): nominate O. typus Heuglin (1877) and the subspecies fortior Thomas (1906a), helleri Frick (1914), and malkensis Frick (1914) from the Ethiopian highlands; dartmouthi Thomas (1906b) from the Ruwenzori Mountains; jacksoni Thomas (1891) from Mount Elgon; orestes Thomas (1900) from Mount Kenya; thomasi Osgood (1910) from the Mau Escarpment; malleus Dollman (1915) and squalus Dollman (1915) from the Aberdare Mountains; and zinki Bohmann (1943) from Mount Kilimanjaro. Soon after Bohmann's (1952) revision, Lawrence and Loveridge (1953) described O. uzungwensis from the Udzungwa Mountains, southcentral Tanzania; without presentation of any character data, Misonne (1974) associated the taxon as the southernmost representative of $O$. typus. Bohmann (1952) generally characterized this geographically disparate assemblage as having a pallid dorsal pelage and buffy post-auricular tufts, relatively short tail, an arched cranial profile with narrow interorbit and large auditory bullae, and lower incisors with two deep grooves. In resurrecting $O$. orestes and $O$. uzungwensis as valid species, however, Carleton \& Byrne (2006) stressed that such traits do not uniformly describe the taxa that Bohmann subsumed under O. typus and that such unique morphologies, isolated on East African mountain tops, exhibit strong morphometric differentiation from $O$. typus proper in Ethiopia. The authors urged continued investigation of taxa allocated to $O$. typus sensu Bohmann (1952) and Misonne (1974).

Based on examination of relevant type specimens and critical historical series in the world's museums, we here integrate evidence from craniodental morphology, linear and geometric morphometry, as well as molecular and cytogenetic data to critically test species limits within the O. typus s.l. complex. In particular, we 1) elevate four additional synonyms of $O$. typus s.l. to species (O.fortior, O. helleri, O. thomasi, $O$. zinki); 2 ) corroborate the specific status of other taxa recently removed from the synonymy of $O$. typus $(O$. dartmouthi, O. jacksoni, O. orestes, and $O$. uzungwensis); and 3) redefine Ethiopian typus as a species complex endemic to the Ethiopian highlands, comprising (based on chromosomal, molecular and morphological grounds) six distinct lineages including $O$. typus s.s., $O$. fortior, $O$. helleri, and three new species (O. yaldeni $\mathbf{s p . ~ n o v . , ~ O . ~ c h e e s m a n i ~} \mathbf{s p .}$ nov., $O$. simiensis $\mathbf{s p .}$ nov.). Our results decidedly underscore the polyphyletic stature of typus, as previously understood by Bohmann and others, and support the independent radiation into alpine environments from different otomyine stocks as conjectured by Carleton \& Byrne (2006).

Discrimination of the above species necessarily required extensive comparison with and robust analyses of Otomys populations that occupy montane altitudes in eastern African mountains (Fig. 1b), namely forms currently assigned to O. tropicalis sensu lato (tropicalis Thomas 1902b, nubilis Dollman 1915, and vivax Dollman 1915 from central Kenyan highlands; elgonis Wroughton 1906 from Mount Elgon; rubeculus Dollman 1915 and ghigii de Beaux 1924 from Uganda; faradjius Hatt 1934 and vulcanis Lönnberg and Gyldenstolpe 1925 from northern and 
eastern Democratic Republic of Congo (DRC); and giloensis Setzer 1953 from the Imatong Mountains, Sudan). We do not recommend nomenclatural changes within the tropicalis complex, but we do provide several profitable lines of inquiry for future research.

TABLE 1. Main classifications of 14 species-group taxa* historically associated with alpine biotopes in eastern Africa (also see Fig. 1). Names in parentheses were allocated as full synonyms to the taxon listed above.

\begin{tabular}{|c|c|c|c|}
\hline Dollman (1915) & Allen (1939), Ellerman (1941) & Bohmann (1952), Misonne (1974) & Musser \& Carleton (2005) \\
\hline O. dartmouthi & O. dartmouthi & $\begin{array}{l}\text { O. typus } \\
\quad \text { (degeni) }\end{array}$ & O. dartmouthi \\
\hline \multirow[t]{2}{*}{ O. fortior } & O. jacksoni & O.t. dartmouthi & O. jacksoni \\
\hline & O.j. helleri & O.t.fortior & \\
\hline \multirow[t]{2}{*}{ O. jacksoni } & O.j. malkensis & O.t.helleri & O. orestes \\
\hline & & O.t. jacksoni & (malleus) \\
\hline \multirow[t]{2}{*}{ O. orestes } & O. orestes & O.t. malkensis & (percivali) \\
\hline & & O.t. malleus & (squalus) \\
\hline \multirow[t]{2}{*}{ O. percivali } & O. percivali & (percivali) & (thomasi) \\
\hline & & O.t. orestes & (zinki) \\
\hline O. thomasi & O. thomasi & O.t. squalus & \\
\hline O.t.malleus & O.t.malleus & O.t. thomasi & O.typus \\
\hline \multirow[t]{2}{*}{ O.t. squalus } & O.t.squalus & O.t.uzungwensis & (degeni) \\
\hline & & O.t. zinki & (fortior) \\
\hline \multirow{4}{*}{$\begin{array}{l}\text { O.typus } \\
\quad(\text { degeni })\end{array}$} & O. typus & & (helleri) \\
\hline & (degeni) & & (malkensis) \\
\hline & O.t.fortior & & \\
\hline & & & O. uzungwensis \\
\hline
\end{tabular}

*Authors and type localities: dartmouthi Thomas 1906b—Uganda, Mt Ruwenzori; degeni Thomas 1902a—Ethiopia, Gombitchu; fortior Thomas 1906a-Ethiopia, Charada Forest; helleri Frick 1914-Ethiopia, Chilalo Divide; jacksoni Thomas 1891—Uganda, Mt Elgon; malkensis Frick 1914—Ethiopia, Malka; malleus Dollman 1915—Kenya, Lake Olbollossat; orestes Thomas 1910-Kenya, Mt Kenya; percivali Dollman 1915-Kenya, 12 mi S Lake Olbollossat; squalus Dollman 1915Kenya, Mt Kinangop; thomasi Osgood 1910-Kenya, Molo; typus Heuglin 1877—Ethiopia, Simien Mts; uzungwensis Lawrence \& Loveridge 1953-Tanzania, Udzungwa Mts; zinki Bohmann 1943—Tanzania, Mt Kilimanjaro.

\section{Material and methods}

Specimens and analytic samples. We examined 321 specimens (skins and skulls) of Otomys from eastern Africa and Ethiopia, from the following museum collections: American Museum of Natural History, New York (AMNH); Durban Natural Science Museum (DM); Field Museum of Natural History, Chicago (FMNH); Liverpool Museum, Liverpool (LM); Museum of Comparative Zoology, Harvard University (MCZ); Muséum National d'Histoire Naturelle, Paris (MNHN); Royal Museum of Central Africa, Tervuren, (RMCA); United States National Museum of Natural History, Smithsonian Institution, Washington, DC (USNM); Museum für Naturkunde, Stuttgart (SM); The Natural History Museum, London (BM); and the Zoological Museum of the Moscow State University, Russia (ZMMU). Locality data from these specimens were used to map species distributions and to delimit geographically cohesive Operational Taxonomic Units (OTUs) for morphometric analyses (Fig. 1). Photographs of study skins and notes were taken to describe variation in pelage colour. Each skull was assigned to a relative age class from 1 (youngest) to 5 (oldest) based on a combination of tooth wear, skull shape, and degree of suture closure, as described by Taylor \& Kumirai (2001). Linear measurements and photographs for geometric morphometric analysis were taken only from intact skulls judged to be "adult" (age classes 4 and 5, as explained below); thus, final multivariate analyses and sample statistics were based only on 247 "adult" (age class 4 and 5) skulls as explained below; of which 128 were $O$. typus s.l., the remainder comprising comparative samples of $O$. tropicalis Thomas 
(1902) s.l. (n=67), O. barbouri Lawrence \& Loveridge (1953) (n=14), O. lacustris G. M. Allen \& Loveridge (1933) $(\mathrm{n}=23)$ and $O$. sungae Bohmann (1943) $(\mathrm{n}=15)$ (Table 2). The entire sample was subdivided into 20 OTUs. Full locality information and Museum accession numbers of all specimens examined are provided within Taxonomic Summary and Appendix 1.

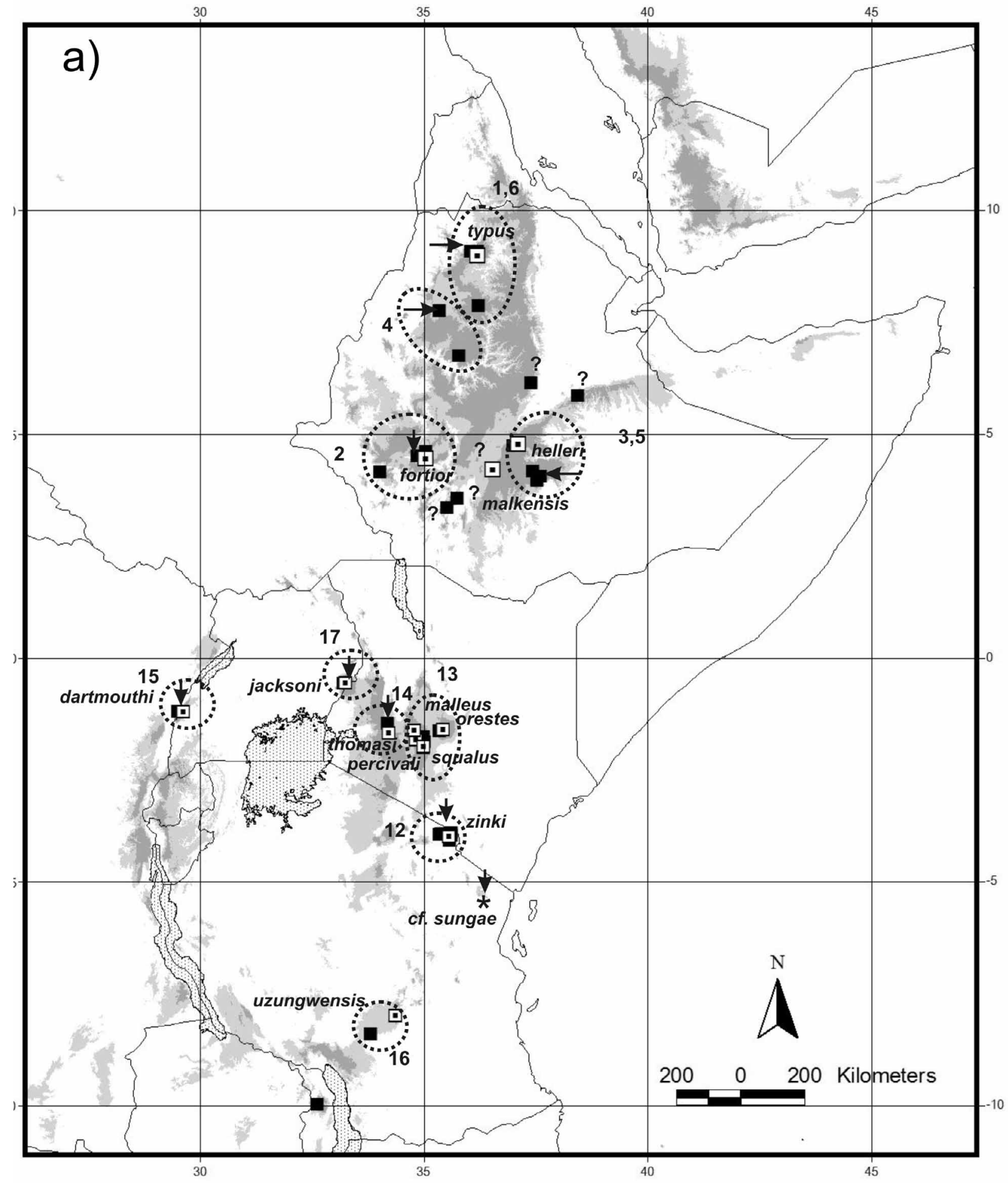




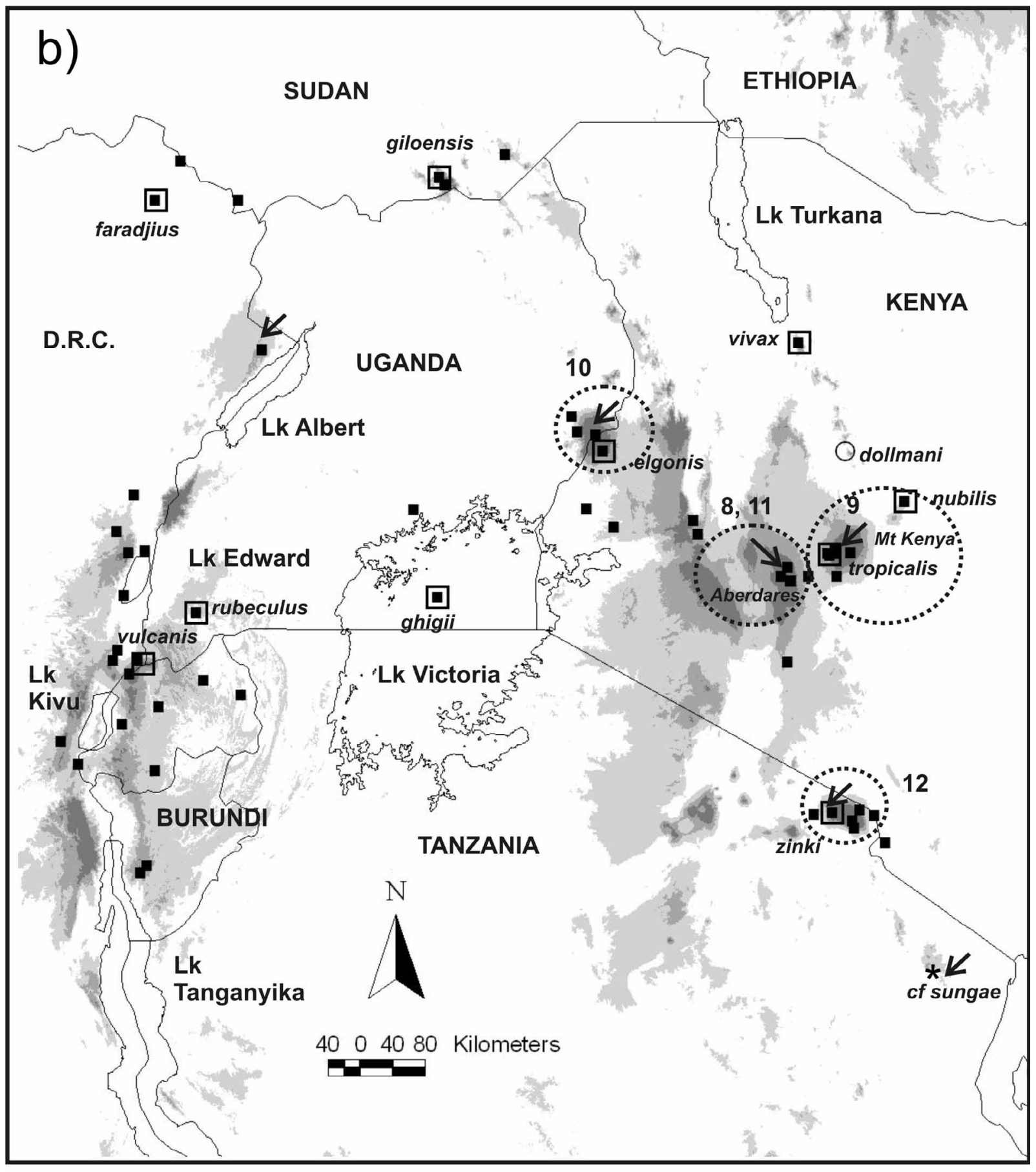

FIGURE 1. Map of east African montane and alpine zones showing distribution of type localities (large, open labeled squares) of forms previously attributed to (a) Otomys typus s. 1. and (b) O. tropicalis s. l. Closed squares represent Museum cranial material examined. Circles enclosed localities assigned to OTU's for this study (in Ethiopia these represent hypothesized taxa based on cytogenetic, molecular and morphological data); numbers indicate OTU numbers in Table 1. Arrows indicate localities from which cytochrome- $b$ sequences were available for this study. The asterisk indicates material from a specimen of uncertain identity assigned to cf. sungae. 
TABLE 2. Summary of east African Otomys material included in final morphometric (Lin. = linear variables; Dor. = dorsal landmarks; Lat. = lateral landmarks) and molecular (Mol.) analyses. Latitude (Lat.) and longitude (Long.) are provided in decimal degrees format.

\begin{tabular}{llll}
\hline Locality & Lat./ Long. & N Lin. N Dor. N Lat.N Mol.(collector) & Museum holdings \\
\hline
\end{tabular}

Otomys typus s.l. (Ethiopia): OTUs 1-7

OTU 1 (n=6): O. typus s.s. $2 \mathrm{n}=58, \mathrm{NFa}=58$ (Ethiopia: Simien Mts, Guna Mt)

Simien Mts (TYPE: typus)

$13.083 \mathrm{~N} 38.2 \mathrm{E} \quad-$

Guna Mt

$11.71 \mathrm{~N} 38.25 \mathrm{E} \quad 4$

Chennek area (Simien Mts)

$13.25 \mathrm{~N} 38.217 \mathrm{E}$

$\begin{array}{cccc}- & - & - & - \\ 4 & - & - & 1 \text { (Lavrenchenko) }\end{array}$

$\mathrm{BM}$

Geech Mt, Simien Mts

$13.083 \mathrm{~N} 38.2 \mathrm{E} \quad 2 \quad 2 \quad 2$

ZMMU

ZMMU

FMNH

OTU 2 (n=8): $O$. fortior, $2 \mathrm{n}=58, \mathrm{NFa}=58$ (Ethiopia: Beletta, Sheko \& Charada Forests)

Kaffa, Charada Forest (TYPE: fortior)

$7.4167 \mathrm{~N} 36.75 \mathrm{E} \quad 1 \quad 1$

$7.533 \mathrm{~N} 36.55 \mathrm{E} \quad 6 \quad-\quad-5$ (Lavrenchenko)

BM

Beletta Forest

$7.067 \mathrm{~N} 35.5 \mathrm{E}$

Sheko Forest

OTU 3 ( $\mathrm{n}=19$ ): O. typus Sp.B (=O. helleri) $2 \mathrm{n}=58, \mathrm{NFa}=58$ (Ethiopia: Bale Mts, Arussi Plateau)

Arussi, Mt Albasso

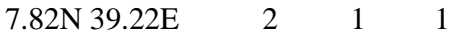

USNM, BM

Bale Mts

$$
\begin{array}{lllll}
\text { 7.1N 39.77E } & 17 & 3 & 3 & 2 \text { (Lavrenchenko) }
\end{array}
$$

MNHN (4),

ZMMU (12),

SM (1)

OTU 4 (n=7): $O$. typus Sp.C (= O. cheesmani sp. nov.) (Ethiopia: Dangila (Lake Tana), Debre Marcos)

Dangila, Lake Tana

Debre Marcos

OTU $5(\mathrm{n}=4)$ : O. typus $\mathrm{Sp} . \mathrm{A}$ (= O. yaldeni sp. nov.), $2 \mathrm{n}=56, \mathrm{NFa}=54$ (Ethiopia: Bale Mts)

Dinsho, Bale Mts

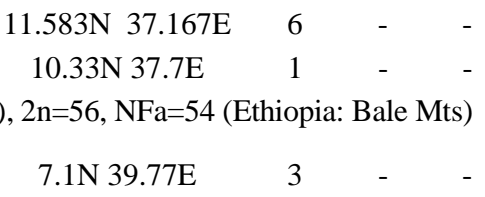

$\mathrm{BM}$

$\mathrm{BM}$

$70 \mathrm{~km} \mathrm{NW}$ of Kebre-Mengist

$6.383 \mathrm{~N} 38.583 \mathrm{E}$

1

2n=54, NF=56 (Ethiopia : Simien Mts)

OTU 6 (n=5): $O$. typus
Sankaber, Simien Mts

$13.233 \mathrm{~N} 38.05 \mathrm{E}$

5

OTU 7 ( $\mathrm{n}=25)$ : O typus, Ethiopia: unassigned localities

Chenca, $2700 \mathrm{~m}$

$6.333 \mathrm{~N} 37.6667 \mathrm{E}$

Chilalo (TYPE: helleri)

Hirna (near), $2520 \mathrm{~m}$

Jimma, $1750 \mathrm{~m}$

Ankober

Bongke, 3000-3200 m

Malka (TYPE: malkensis)

Gombitchu 2450 m (TYPE: degeni)

Otomys tropicalis s.l. (East Africa): OTUs 8-11

\section{$7.8333 \mathrm{~N} 39.333 \mathrm{E}$}

$9.2 \mathrm{~N} 41.0167 \mathrm{E}$

$7.65 \mathrm{~N} 36.783 \mathrm{E}$

$9.567 \mathrm{~N} 39.717 \mathrm{E}$

$6.083 \mathrm{~N} 37.383 \mathrm{E}$

$7.117 \mathrm{~N} 38.617 \mathrm{E}$

$9.333 \mathrm{~N} 38.666 \mathrm{E}$

OTU 8 ( $\mathrm{n}=19)$ : O. t. tropicalis (Aberdares) $*=$ molecular outlier

"Aberdares"

"Aberdares, moorland"

Aberdare Mts, Changongorra, 7,000 ft (2140 m)

Mt Kinangop, $2700 \mathrm{~m}$

Nyeri, 16 km E

Ololua Forest Reserve

Aberdares National Park Fishing Lodge, $9500 \mathrm{ft}$

Aberdares, Ruhuruini *

OTU 9 (n=25): O. t. tropicalis (Mt Kenya)

Kangaita, 6 mi N Kerugoy

"Mt Kenya"
$-0.3167 \mathrm{~S} 36.7 \mathrm{E}$

$\begin{array}{ccccc} & 6 & 2 & 1 & \\ -0.4667 \mathrm{~S} 36.733 \mathrm{E} & 3 & 5 & 6 & 4 \text { (E. Verheyen) } \\ -0.4667 \mathrm{~S} & 1 & - & - & - \\ 36.7333 \mathrm{E} & & & & - \\ -0.467 \mathrm{~S} 36.75 \mathrm{E} & 1 & - & - & - \\ -0.417 \mathrm{~S} 36.9333 \mathrm{E} & 1 & 1 & 1 & - \\ -1.3667 \mathrm{~S} 36.7 \mathrm{E} & 1 & 2 & & 1 \text { (E. Verheyen) } \\ -0.3167 \mathrm{~S} 36.7 \mathrm{E} & 5 & - & - & 3 \text { (McLellan) } \\ -0.4167 \mathrm{~S} & 1 & - & 1 & 1 \text { (E. Verheyen) } \\ 36.6333 \mathrm{E} & & & & \end{array}$

MNHN (1),

ZMMU (2)

$\mathrm{BM}$

ZMMU

SM

$\mathrm{SM}, \mathrm{CM}$

SM

USNM

SM

SM

$\mathrm{CM}$

$\mathrm{BM}$

MRAC(1),

USNM(1),

$\mathrm{BM}(4)$

MRAC

USNM

MNHN

USNM

MRAC

USNM

MRAC 
TABLE 2 Continued

\begin{tabular}{|c|c|c|c|c|c|c|}
\hline \multirow{2}{*}{$\begin{array}{l}\text { Locality } \\
\text { Mt Kenya KWS NM Gate }\end{array}$} & Lat./ Long. & \multicolumn{4}{|c|}{ N Lin. N Dor. N Lat.N Mol.(collector) } & \multirow{2}{*}{$\frac{\text { Museum holdings }}{\text { MRAC }}$} \\
\hline & $-0.1667 \mathrm{~S} 37.15 \mathrm{E}$ & 1 & 2 & 1 & 1 (E. Verheyen) & \\
\hline Mt Kenya Met Station & $\begin{array}{l}-0.1667 \mathrm{~S} \\
37.2167 \mathrm{E}\end{array}$ & 5 & 6 & 6 & 5 (E. Verheyen) & MRAC \\
\hline Jomberi Range, NE of Mt Kenya (TYPE: nubilis) & $0.4127 \mathrm{~N} 38.0 \mathrm{E}$ & 1 & & & & $\mathrm{BM}$ \\
\hline Mt Nyiru, S of Lake Rudolph (TYPE: vivax) & $2.17 \mathrm{~N} 36.83 \mathrm{E}$ & 1 & & & & $\mathrm{BM}$ \\
\hline $\begin{array}{l}\text { Mt Kenya, West Slope, } 10,000 \mathrm{ft} \quad \text { (3048 m) } \\
\text { (TYPE: tropicalis) }\end{array}$ & $\begin{array}{l}-0.1667 \mathrm{~S} \\
37.1667 \mathrm{E}\end{array}$ & 1 & & & & $\mathrm{BM}$ \\
\hline Mt Kenya, West Slope, 7,000 - 12,000 ft & $\begin{array}{l}-0.1667 \mathrm{~S} \\
37.1667 \mathrm{E}\end{array}$ & 8 & & & & $\begin{array}{l}\operatorname{USNM}(7) \\
\operatorname{AMNH}(1)\end{array}$ \\
\hline Solai, Mt Kenya & $-0.1 \mathrm{~S} 37.23 \mathrm{E}$ & 3 & & & & $\mathrm{BM}$ \\
\hline $\begin{array}{l}\text { Mt Kenya, Naro } \\
\text { Moru, } 10,000 \mathrm{ft}\end{array}$ & $\begin{array}{l}-0.1833 \mathrm{~S} \\
37.1667 \mathrm{E}\end{array}$ & - & & & 1 (McLellan) & USNM \\
\hline \multicolumn{7}{|l|}{ OTU $10(\mathrm{n}=15):$ O. t. elgonis (Mt Elgon) } \\
\hline Mt Elgon, Coletatomoi & ? & 1 & 1 & 1 & & MCZ \\
\hline Junction camp at foot of Mt Elgon & $1.15 \mathrm{~N} 34.583 \mathrm{E}$ & 1 & & & & MRAC \\
\hline $\begin{array}{l}\text { Mt Elgon. 15km from Chorlim Gate, bamboo } \\
\text { zone }\end{array}$ & $1.15 \mathrm{~N} 34.5833 \mathrm{E}$ & 2 & 2 & 2 & 3 (McLellan) & USNM \\
\hline Mt Elgon, Bumasola Village & $1.18 \mathrm{~N} 34.38 \mathrm{E}$ & 1 & & & 1 (Taylor) & DM \\
\hline Mt Elgon, Sipi & $1.35 \mathrm{~N} 34.3167 \mathrm{E}$ & 7 & 6 & 5 & & $\mathrm{MCZ}$ \\
\hline S. Elgon & $1.15 \mathrm{~N} 34.583 \mathrm{E}$ & 2 & & & & MRAC \\
\hline $\begin{array}{l}\text { Elgonyi, Mt Elgon, } 7000 \text { ft (2100 m) (TYPE: } \\
\text { elgonis) }\end{array}$ & $0.967 \mathrm{~N} 34.6667 \mathrm{E}$ & 1 & & & & $\mathrm{BM}$ \\
\hline \multicolumn{7}{|c|}{ OTU 11 ( $\mathrm{n}=11)$ : O. cf. tropicalis ( $\mathrm{m} 1$ with 5 laminae: Aberdares Summit) } \\
\hline Aberdares & $-0.3167 \mathrm{~S} 36.7 \mathrm{E}$ & 1 & & & & $\mathrm{BM}$ \\
\hline Aberdares Mts, summit $11,000 \mathrm{ft}$ & $-0.3167 \mathrm{~S} 36.7 \mathrm{E}$ & 9 & 7 & 9 & & USNM \\
\hline Mt Kinangop, Aberdares, $2700 \mathrm{~m}$ & $-0.467 \mathrm{~S} 36.75 \mathrm{E}$ & 1 & & & & MNHN \\
\hline \multicolumn{7}{|l|}{ Otomys typus s.l. (East Africa): OTUs 12-17 } \\
\hline \multicolumn{7}{|l|}{ OTU $12(\mathrm{n}=12)$ : O. orestes zinki (Mt Kilimanjaro) } \\
\hline "Kilimanjaro" & $-3.0 \mathrm{~S} 37.5 \mathrm{E}$ & 1 & & & & SM \\
\hline $\begin{array}{l}\text { Mt Kilimanjaro NP, 7km N, 2.5km W Maua, } \\
2477 \mathrm{~m}\end{array}$ & $\begin{array}{l}-3.2078 \mathrm{~S} \\
37.4469 \mathrm{E}\end{array}$ & 1 & & & 1 (Stanley) & FMNH \\
\hline Kilimanjaro, $16 \mathrm{~km} \mathrm{~N}, 4.5 \mathrm{~km} \mathrm{~W}$ Maua $3995 \mathrm{~m}$ & $\begin{array}{l}-3.1261 \mathrm{~S} \\
37.4267 \mathrm{E}\end{array}$ & 1 & & 1 & & FMNH \\
\hline $\begin{array}{l}\text { Mt Kilimanjaro East, Maundi Crater, } 3270 \text { m, } \\
\text { grassland }\end{array}$ & $-3.0667 \mathrm{~S} 37.5 \mathrm{E}$ & 6 & 5 & 4 & 4 (E. Verheyen) & MRAC \\
\hline $\begin{array}{l}\text { Mt Kilimanjaro West, Londorosi } 2350 \mathrm{~m} \text {, } \\
\text { forest }\end{array}$ & $-3.05 \mathrm{~S} 37.15 \mathrm{E}$ & 2 & 3 & 3 & & MRAC \\
\hline $\begin{array}{l}\text { Mt Kilimanjaro West, Shira, } 3000 \mathrm{~m} \text {, moorland } \\
\text { OTU } 13(\mathrm{n}=15) \text { : O. orestes (Mt Kenya \& Aberdar }\end{array}$ & es) $-3.0333 \mathrm{~S} 37.2 \mathrm{E}$ & 1 & 1 & 1 & & MRAC \\
\hline $\begin{array}{l}\text { Mt Kenya, Teleki Valley, 13,000ft (3962 m) } \\
\text { (TYPE: orestes) }\end{array}$ & $-0.1333 \mathrm{~S} 37.25 \mathrm{E}$ & 1 & & 1 & & $\mathrm{BM}$ \\
\hline Aberdare Mts, summit $11,000 \mathrm{ft}$ & $-0.3167 \mathrm{~S} 36.7 \mathrm{E}$ & 2 & & 1 & & USNM \\
\hline $\begin{array}{l}\text { Aberdares National Park Fishing Lodge, 9000- } \\
9500 \mathrm{ft}\end{array}$ & $-0.3167 \mathrm{~S} 36.7 \mathrm{E}$ & 2 & & 1 & 2 (McLellan) & USNM \\
\hline Mt Kenya, $13,500 \mathrm{ft}$ & $\begin{array}{l}-0.1667 \mathrm{~S} \\
37.167 \mathrm{E}\end{array}$ & 2 & & 2 & & USNM \\
\hline Mt Kenya , 14,600-15,000ft & $\begin{array}{l}-0.1667 \mathrm{~S} \\
37.167 \mathrm{E}\end{array}$ & 3 & & 2 & & AMNH \\
\hline Aberdares, $12,500 \mathrm{ft}$ & $\begin{array}{l}-0.4667 \mathrm{~S} \\
36.7333 \mathrm{E}\end{array}$ & 1 & & 1 & & AMNH \\
\hline Aberdares, moorland & $\begin{array}{l}-0.4667 \mathrm{~S} \\
36.7333 \mathrm{E}\end{array}$ & 1 & 1 & 1 & 1 (E. Verheyen) & MRAC \\
\hline $\begin{array}{l}\text { Lake Ol Bolossot, } 20 \mathrm{~km} \mathrm{~S} \text {, Naivasha District } \\
\text { (TYPE: percivali) }\end{array}$ & $-0.42 \mathrm{~S} 36.5 \mathrm{E}$ & 1 & & & & $\mathrm{BM}$ \\
\hline
\end{tabular}




\begin{tabular}{|c|c|c|c|c|c|c|}
\hline \multirow{2}{*}{$\begin{array}{l}\text { Locality } \\
\text { Lake Ol Bolossot, Naivasha District (TYPE: } \\
\text { malleus) }\end{array}$} & \multirow{2}{*}{$\begin{array}{l}\text { Lat./ Long. } \\
-0.1667 \mathrm{~S} 36.45 \mathrm{E}\end{array}$} & \multicolumn{4}{|c|}{ N Lin. N Dor. N Lat.N Mol.(collector) } & \multirow{2}{*}{$\begin{array}{c}\text { Museum holdings } \\
\mathrm{BM}\end{array}$} \\
\hline & & 1 & & & & \\
\hline Mt Kinangop, Aberdares (TYPE: squalus) & $-0.62 \mathrm{~S} 36.7 \mathrm{E}$ & 1 & & & & $\mathrm{BM}$ \\
\hline \multicolumn{7}{|c|}{ OTU $14(\mathrm{n}=5)$ : O. orestes thomasi (Mau Escarpment and Uasin Gishu Plateau) } \\
\hline Molo, Uasin Gishu Plateau & $-0.2333 \mathrm{~S} 35.733 \mathrm{E}$ & 4 & 4 & 4 & & FMNH \\
\hline Guas Ngishu Plateau, $32 \mathrm{~km} \mathrm{~N}$ of Ravine, $9000 \mathrm{ft}$ & $0.05 \mathrm{~N} 35.7167 \mathrm{E}$ & 1 & 1 & & & USNM \\
\hline \multicolumn{7}{|l|}{ OTU 15 (n=9): O. typus dartmouthi (Ruwenzoris) } \\
\hline $\begin{array}{l}\text { Ruwenzori East, Mubuku Valley, } 12,500 \mathrm{ft} \\
\text { (TYPE: dartmouthii) }\end{array}$ & $0.37 \mathrm{~N} 30.0 \mathrm{E}$ & 4 & & & & $\mathrm{BM}$ \\
\hline Ruwenzori Mts, Lk Bujuku, 11050 13,050ft & $\begin{array}{l}-0.3833 \mathrm{~S} \\
29.9333 \mathrm{E}\end{array}$ & 4 & 3 & 3 & 1 (Kerbis) & FMNH \\
\hline Wusuwameso, 4380m & $0.3833 \mathrm{~N} 29.85$ & 1 & & & & MRAC \\
\hline \multicolumn{7}{|c|}{ OTU 16 ( $\mathrm{n}=10)$ : O. typus uzungwensis (Eastern Arc Range) } \\
\hline Kigogo, Udzungwa Mts, $6000 \mathrm{ft}$ & $-8.6167 \mathrm{~S} 35.25 \mathrm{E}$ & 3 & 2 & 3 & & MCZ \\
\hline $\begin{array}{l}\text { Dabaga, Iringa District, Udzungwa Mts, } 6000 \mathrm{ft} \\
\text { (TYPE: uzungwensis) }\end{array}$ & $\begin{array}{l}-8.1167 \mathrm{~S} \\
35.9167 \mathrm{E}\end{array}$ & 6 & 6 & 7 & & $\mathrm{MCZ}$ \\
\hline Nyika Plateau, Malawi, $7000 \mathrm{ft}$ & $-10.583 \mathrm{~S} 33.75 \mathrm{E}$ & 1 & 1 & 1 & & MCZ \\
\hline \multicolumn{7}{|l|}{ OTU 17 (n=3): O. typus jacksoni (Mt Elgon) } \\
\hline $\begin{array}{l}\text { Mt Elgon, crater, ca 3300-4200 m (TYPE: } \\
\text { jacksoni) }\end{array}$ & $1.17 \mathrm{~N} 34.533 \mathrm{E}$ & 1 & 1 & 1 & & $\mathrm{BM}$ \\
\hline Kaburoni, Mt Elgon & $1.167 \mathrm{~N} 34.4833 \mathrm{E}$ & 1 & 1 & 1 & & MCZ \\
\hline $\begin{array}{l}\text { Mude Cave Camp, Mt Elgon, } 3600 \mathrm{~m} \\
\text { OTU } 18 \text { (n=13): O. barbouri (Mt Elgon) }\end{array}$ & $1.167 \mathrm{~N} 34.4833 \mathrm{E}$ & 1 & & & 1 (Taylor) & $\mathrm{DM}$ \\
\hline Mount Elgon: Mission Delomo & $1.17 \mathrm{~N} 34.49 \mathrm{E}$ & 5 & 4 & 2 & & MNHN \\
\hline Mude Cave Camp, Mt Elgon, 3600m & $\begin{array}{c}1.167 \mathrm{~N} \\
34.48333 \mathrm{E}\end{array}$ & 4 & & & 2 (Taylor) & $\mathrm{DM}$ \\
\hline Kaburoni, Mt Elgon (TYPE: barbouri) & $1.167 \mathrm{~N} 34.4833 \mathrm{E}$ & 4 & 5 & 3 & & $\mathrm{MCZ}$ \\
\hline \multicolumn{7}{|c|}{ OTU 19 (n=18): O. lacustris (Eastern Arc Range, S Highlands, Tanzania) } \\
\hline $\begin{array}{l}\text { Madehani, Ukinga Mts, NE end of Lk Nyasa, } \\
7000 \mathrm{ft} \text { (2134 m) (TYPE: lacustris) }\end{array}$ & $\begin{array}{l}-9.3333 \mathrm{~S} \\
34.0167 \mathrm{E}\end{array}$ & 8 & 4 & 7 & & $\begin{array}{l}\operatorname{MCZ}(7) \\
\operatorname{FMNH}(1)\end{array}$ \\
\hline Ukaguru Mts,Mamiwa-Kisara FR, 1900m & $\begin{array}{l}-6.3792 \mathrm{~S} \\
36.9361 \mathrm{E}\end{array}$ & 4 & 4 & 4 & & FMNH \\
\hline Udzungwa Mts, 4km W, 5km N Chita, 1460 m & $-8.475 \mathrm{~S} 35.907 \mathrm{E}$ & 1 & 1 & 1 & & FMNH \\
\hline $\begin{array}{l}\text { Udzungwa Mts, } 19.5 \mathrm{~km} \mathrm{~N}, 0.5 \mathrm{~km} \text { W Chita, } 2000 \\
\mathrm{~m}\end{array}$ & $-8.347 \mathrm{~S} 35.939 \mathrm{E}$ & 1 & & & & FMNH \\
\hline Lucheche River, Abercorn (=Mbala) & $-8.76667 \mathrm{~S} 31.4 \mathrm{E}$ & 1 & & 1 & & $\mathrm{MCZ}$ \\
\hline Dabaga, Iringa District, Uzungwe Mts, $6000 \mathrm{ft}$ & $-8.117 \mathrm{~S} 35.917 \mathrm{E}$ & 1 & 1 & & & $\mathrm{MCZ}$ \\
\hline Mt Rungwa Forest Reserve & $-9.133 \mathrm{~S} 33.667 \mathrm{E}$ & 1 & 1 & 1 & & FMNH \\
\hline $\begin{array}{l}\text { Mbizi Mts (Forest Reserve), } 0.5 \mathrm{~km} \mathrm{S,} 3 \mathrm{~km} \mathrm{E} \\
\text { Wipanga, } 2300 \mathrm{~m}\end{array}$ & $-7.875 \mathrm{~S} 31.667 \mathrm{E}$ & 1 & & & & FMNH \\
\hline Chingombe, Ufipa Plateau & $-7.875 \mathrm{~S} 31.667 \mathrm{E}$ & & & & 1 (Genbank) & MRAC \\
\hline Bondwa, Uluguru & $-7.1 \mathrm{~S} 37.64 \mathrm{E}$ & & & & 1 (Genbank) & MRAC \\
\hline Igale, Poroto Mts & & & & 1 & & FMNH \\
\hline \multicolumn{7}{|l|}{ OTU $20(\mathrm{n}=9)$ : $O$. sungae (Usambara Mts, Tanzania) } \\
\hline $\begin{array}{l}\text { Kidunda Forest (2047 m), Kiranga, Usambaras, } \\
\text { Tanzania }\end{array}$ & $-4.976 \mathrm{~S} 38.446 \mathrm{E}$ & 1 & & & 1 (Laudisoit) & MRAC \\
\hline Shume, Lushoto, $7000 \mathrm{ft}$ (2134 m), Tanzania & $-4.8 \mathrm{~S} 38.25 \mathrm{E}$ & 6 & & & & $\begin{array}{l}\operatorname{USNM}(3) \\
\operatorname{TM}(3)\end{array}$ \\
\hline Sunga. Usambaras, Tanzania & $-4.53 \mathrm{~S} 38.233 \mathrm{E}$ & 1 & & & & USNM \\
\hline Magamba, Usambaras, Tanzania $5200 \mathrm{ft}(1733 \mathrm{~m})$ & & 1 & & & & FMNH \\
\hline
\end{tabular}


Morphology and morphometrics. Craniodental characters. Four qualitative variables historically applied in Otomys alpha taxonomy were scored for 267 skulls representing the 20 OTUs, including both intact skulls and those fragmented crania that suitably preserved the character in question. Character states of those four discrete variables are recognized as follows.

1. The approximate angle of inflexion where the nasal bones expand distally (see Taylor \& Kumirai 2001; Tay-

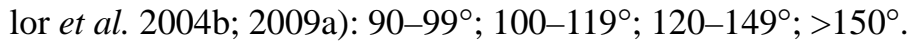

2. The number of grooves in the anterior face of the lower incisor: single, deep medial groove (1); one medial groove plus faint trace of a second lateral groove $(1+\mathrm{t})$; one medial groove plus a shallow but distinct lateral groove $(1+s)$; two well defined grooves, the lateral and medial corrugations approximately equal in depth (2).

3. The number of laminae in the upper third molar (M3): 6, 7, 8, or 9 complete laminae. The M3 was viewed in lateral aspect to verify that the posteriormost lamina was fully defined from the crown to the base.

4. The number of laminae in the lower first molar (m1): 4 complete laminae; $4+1 ; 5$ complete laminae. The intermediate state $(4+1)$ was encountered infrequently; in this condition, the anterior lamina was subdivided, possessing a small, anteromedial projection (presumptive fifth lamina).

The shape of the petrotympanic (= stapedial) foramen, whether a round hole or a slit-like gutter (illustrated in Meester et al. 1986), was also recorded, but a round hole was invariantly observed in all specimens of all OTUs and taxa we examined; only examples of $O$. angoniensis Wroughton (1906), a species not considered herein, exhibit the slit-like condition.

Linear measurements. Ten cranial dimensions, as defined and illustrated in Taylor \& Kumirai (2001), were measured using Mitotoyo calipers, with resolution to $0.01 \mathrm{~mm}$ and accuracy to $0.1 \mathrm{~mm}$ : greatest length of skull (GLS), measured dorsally, equivalent to occipito-nasal length; depth of braincase (BCD), measured vertically at basioccipital; mandible length (MDL), greatest length of the mandible excluding teeth; maximum length of anterior palatal foramen (APF); nasal width (NAW), greatest width across nasals at right angle to skull axis; maxillary tooth row length (MXTRL), distance from anterior edge of first maxillary tooth to posterior edge of last maxillary tooth at crown; interorbital constriction (IOC), least distance dorsally between the orbits; zygomatic width (ZYW), greatest distance between the outer margins of the zygomatic arches; palatal length (PAL), from anterior edge of premaxillae to anterior-most point on posterior edge of palate; greatest length of bulla (BUL), along the longitudinal axis and excluding the eustachian tube.

Almost all the specimens were measured by one of us (PJT). Crania of 15 individuals of tropicalis (from Aberdares) and typus s.l. (from Beletta Forest, Jimma, Ethiopia) were measured by MDC after calibrating landmarks using specimens measured by both PJT and MDC. Craniometric data for 31 individuals from Ethiopia were collected by LAL whose dataset including 21 variables, seven of which were identical to those defined above (all but GLS and PAL). Comparison of several individuals measured by both LAL and PJT confirmed the accuracy of the landmarks used in these definitions. Based on very significant $(\mathrm{P}<<0.001)$ correlations obtained between ZYW and both GLS and PAL (in the data set of PJT), we estimated values for these missing variables (GLS and PAL) in the Ethiopian dataset of LAL using regression analysis. In this way we were able to compare data from LAL directly to those obtained by PJT and MDC.

Standard descriptive statistics (mean, range, and standard deviation) were derived for adult specimens (age classes 4 and 5) of all OTUs. To search for patterns among individual variables, Analysis of Variance (ANOVA) was performed using XLSTAT 2008.2.03 (Addinsoft 2008), followed by Tukey's HSD (Honestly Significant Difference) multiple comparison tests where more than two groups were involved. For multivariate analyses, variables were transformed to their natural logarithms in order to correct for size differences (hence unequal contributions to variance matrices) among linear variables (Marcus 1990; Carleton \& Byrne 2006). Log-transformed linear data were subjected to exploratory principal component analysis (PCA) to observe relationships between individuals from different sexes, age classes, or geographic samples (OTUs). Canonical variates analysis (CVA) of the log-transformed variables was used to test the significance of and reveal phenotypic patterns between OTUs. Multivariate analyses of linear data were conducted using XLSTAT version 2008.2.03 (Addinsoft 2008) and NTSYS-pc (Rohlf 1997).

Geometric morphometrics. Using a Sony Cybershot DSC-H2 digital camera (6 megapixel; 12x optical zoom, macro function), mounted on a tripod at a fixed distance of approximately $20 \mathrm{~cm}$ from the skull (which was always mounted on graph paper), dorsal and lateral images were taken for between 123 (dorsal) and 111 (lateral) skulls from the same OTUs used for linear measurements.

Landmark placement and further analyses were performed using the thin plate spline (TPS) series of programmes. The programme tpsDig version 2.1 (Rohlf 2006) was used to capture landmarks in two dimensions for 
dorsal (14 landmarks) and lateral (14 landmarks) views (see Figs. 9 and 11 for position of landmarks on lateral and dorsal images respectively). The programme tpsRelw version 1.42 (Rohlf 2005) was used to conduct a Generalised Procrustes Analysis or GPA (Generalised Least Squares, GLS, of Rohlf \& Slice 1990), which serves to translate, rotate and scale the landmark configurations, and produces a consensus configuration for the entire suite of specimens in the analysis via a series of iterations. GPA residuals are further decomposed into both non-uniform (nonaffine), and uniform (affine) shape components. Non-affine shape expresses localized shape changes, and is represented by the weights matrix, W, of partial warp scores. Affine shape expresses shape changes that affect the entire configuration (i.e. dilation or sheer), and this component is represented by two vectors, U1 and U2. Together, U + W represent total shape. Relative warps analysis performs a principal component analysis of the covariance matrix of the total shape matrix $(U+W)$. The programme tpsRegr version 1.35 (Rohf 2007) was used to perform a twoway MANOVA of the weights matrix to test for significant differences between sexes, and between age classes 3 and 4 , in the Tora sample.

For introductions to geometric morphometrics and its application to rodent systematics see Corti (1993), Marcus and Corti (1996), Rohlf (1998), Rohlf and Marcus (1993), Rohlf (2002), and Taylor et al. (2004a, 2005, 2009a, b).

Cytogenetic methods. The chromosomal analysis was performed on Ethiopian samples of $O$. typus s.s. $(\mathrm{n}=1)$, O. fortior (n=6), "Sp. A" (= O. yaldeni sp. nov.; see Taxonomic Summary) (n=1), "Sp. B” (= O. helleri; see Taxonomic Summary) (n=6) and "Sp. D" (= O. simiensis sp. nov.; see Taxonomic Summary) (n=4). Somatic metaphases were prepared from bone marrow by the usual air-drying technique according to Ford and Hamerton (1956). Slides were stained with $4 \%$ Giemsa in phosphate buffer with $\mathrm{pH}=7.0$.

Molecular methods. Forty-four specimens (Appendix 2) were analyzed representing all but two forms (thomasi and uzungwensis) recognized within $O$. typus s.l., three forms currently assigned to $O$. tropicalis s.l., three species from eastern Africa (O. barbouri, $O$. denti and $O$. lacustris), two species from West Africa (O. occidentalis Dieterlen \& Van der Straeten (1992) and O. burtoni Thomas (1918)) and three from southern Africa (O. angoniensis, O. irroratus Brants (1827) and Parotomys brantsii A. Smith (1834)). These specimens represent a subset of those analyzed morphologically and cytogenetically (Table 2, Appendix 1) for which appropriate material was available for molecular investigation. Nine species from within the subfamily Murinae but of different levels of relatedness to the Otomyini were selected as outgroups for constructing the phylogeny and for approximating the divergence times of lineages from cyt $b$ sequence data (Batomys granti Thomas (1895), Phloeomys sp., Rattus norvegicus (Berkenhout, 1769), Mus musculus Linnaeus (1758), Micaelamys namaquensis (A. Smith, 1834), Aethomys sp., Arvicanthis neumanni Matschie (1894), Lemniscomys striatus (Linnaeus, 1758) and Oenomys hypoxanthus (Pucheran, 1855). In addition, a phylogeny was reconstructed from combined cyt $b$ and 12S rRNA sequences of 21 Otomyini specimens using Mus musculus, Micaelamys namaquensis, Arvicanthis somalicus and Lemniscomys striatus (Linnaeus, 1758) as outgroups (Appendix 2).

Total genomic DNA was extracted from frozen or ethanol-preserved soft tissue samples using phenol-chloroform procedures (Sambrook et al. 1989). Polymerase chain reaction (PCR) amplification of the complete mitochondrial cyt $b$ gene and a portion of $12 \mathrm{~S}$ rRNA (small ribosomal subunit, $\pm 800 \mathrm{bp}$ ) followed standard methodology (Saiki et al. 1988). Conserved primers used to amplify cyt $b$ fragments were L14724 and H15915 (Pääbo \& Wilson 1988) and the Otomys-specific L15267 (Taylor et al. 2009a), and for amplifying 12S rRNA, L82 and H900 (Allard \& Honeycutt 1992). Typical cycling conditions were: initial denaturation (2 min at $\left.94{ }^{\circ} \mathrm{C}\right) ; 35$ cycles of denaturation $\left(30 \mathrm{~s}\right.$ at $\left.94{ }^{\circ} \mathrm{C}\right)$, primer annealing $\left(30 \mathrm{~s}\right.$ at $48-55^{\circ} \mathrm{C}$, primer-dependent), DNA extension $(35 \mathrm{~s}$ at $\left.72{ }^{\circ} \mathrm{C}\right)$; a final extension phase $\left(5 \mathrm{~min}\right.$ at $\left.72{ }^{\circ} \mathrm{C}\right)$. Sequences were determined from purified PCR products (HighPure, Roche) using big dye-terminator chemistry (Sanger et al. 1977) on ABI3100/ABI3130 Analyzers (Applied Biosystems). Outgroup sequences were sourced on Genbank ${ }^{\mathrm{TM}}$ except for the 12S rRNA sequence for Micaelamys namaquensis obtained in this study. Genbank accession numbers for newly sequenced cyt $b$ and 12S rRNA gene fragments are provided in Appendix 2

Sequences were aligned in ClustalX (Thompson et al. 1997) and the functional reading frame for the proteincoding cyt $b$ gene was verified using MacClade version 4.07 (Maddison \& Maddison 2000). The 12S rRNA secondary structure model for Mus (Damberger \& Gutell unpubl. in Sullivan et al. 1995) was used to improve the alignment. Phylogenetic tree reconstruction involved model-based maximum likelihood (ML, Felsenstein 1981) and Bayesian inference methods (BPP, Huelsenbeck \& Ronquist 2001) as well as parsimony (Kluge \& Farris 1969; unweighted and six-parameter-weighted [6PP]: Williams \& Fitch 1990; Lanave et al. 1984; Rodriguez et al. 1990) and distance-based neighbour-joining (NJ, Saitou \& Nei 1987) approaches. The best-fit models of sequence evolution for the overall cyt $b$ gene $(\mathrm{GTR}+\mathrm{I}+\mathrm{G}), 12 \mathrm{~S}$ rRNA $(\mathrm{TrN}+\mathrm{I}+\mathrm{G})$, the combined cyt $b / 12 \mathrm{~S}$ rRNA data 
$(\mathrm{GTR}+\mathrm{I}+\mathrm{G})$ and the three codon positions of cyt $b$ (pos 1: $\mathrm{GTR}+\mathrm{I}+\mathrm{G}, \operatorname{pos} 2: \operatorname{TrN}+\mathrm{I}+\mathrm{G}$, pos 3: $\operatorname{TrN}+\mathrm{I}+\mathrm{G})$ were estimated using MODELTEST (Posada \& Crandall 1998; 2001; Posada 2006). PAUP version $4.0 b 10$ (Swofford 2002) was used for $\mathrm{NJ}$ analysis based on uncorrected $p$-distances (Nei 1987) and corrected genetic distances (cyt $b$ : GTR+I+G; 12S: TrN+I+G), for executing heuristic parsimony and likelihood searches with TBR branch swapping and random taxon additions (ML: 10; MP: 100) and to produce a 50\% majority-rule consensus of minimal-length parsimony trees. Nodal support was assessed by non-parametric bootstrap analysis (Felsenstein 1985; 1000 iterations for NJ, parsimony and ML). Bayesian analysis (MrBayes version 3.1.2, Huelsenbeck \& Ronquist 2003) of the independent cyt $b$ data (1140 bp) and the concatenated cyt $b$ / 12S rRNA sequences (1940 bp) were conducted to empirically determine the posterior probability distribution of trees, branch lengths and substitution parameters using four Markov Chain Monte Carlo chains, each starting from random trees, running simultaneously for 5x $10^{6}$ generations (sampling and recording every $100^{\text {th }}$ generation). The first $5 \times 10^{3}$ were discarded as "burn-in". The average standard deviation of split frequencies was calculated to assess the similarity between the sets of trees recovered from two independent runs. Alignment gaps in $12 \mathrm{~S}$ rRNA sequences of the combined data were coded as binary characters ( 0 gap absent / 1 gap present) according to the "simple indel coding" approach (Simmons \& Ochoterena 2000) and added as additional characters to the end of the data matrix, while indels within the matrix were treated as "missing". The binary (restriction) model were specified for the nine binary characters in MrBayes (Command: Lset Coding=Variable).

Divergence date estimation. Given that the assumption of a global molecular clock was rejected for cyt $b$ (using criteria outlined by Felsenstein 1988), Bayesian approximation under an uncorrelated, relaxed molecular clock (Drummond et al. 2006) was used to estimate mean and 95\% confidence limits of divergence dates for the major lineages recovered in the cyt $b$ tree. The analysis was executed using BEAST v1.4 package (Drummond \& Rambaut 2006a), BEAUTI v1.4 (Drummond \& Rambaut 2006b) and TRACER v1.3 (Rambaut \& Drummond 2005). The best-fit substitution model for each codon position was assumed and four minimum fossil calibration dates were specified: 3.5 million years (Myr) for the minimum age for the oldest known Otomys fossil from southern Africa, O. cf. gracilis (Pocock 1987; Upper Pliocene, Makapansgat [at least 3.7-3.5 Mya old; Partridge 1973]); 6.0 Myr for the divergence of Arvicanthini and Otomyini lineages (Winkler 2002; Rowe et al. 2008); the Mus-Rattus lineage split at 11.0 Myr (Jacobs \& Downs 1994; Rowe et al. 2008) and the divergence of Batomys and Phloeomys at 12.1 Myr (Rowe et al. 2008). To accomplish the date calibrations, we specified a normal prior (minimum estimated fossil age \pm 0.1 ) for each node height. We specified no mean substitution rate and the tree model was selected for root height, so to allow the program to estimate this. FigTree version 1.3.1 was used for visualization of the dated tree.

Ecological methods. Defining bioclimatic niches. We used the programme BIOCLIMAv (Beta 1.1) (Moussalli et al. 2003) in ArcView version 3.2a to obtain data for $O$. typus s.l. ( $\mathrm{n}=47$ localities) for altitude and eight bioclimatic variables (WORLDCLIM version 1.4: http://biogeo.berkeley.edu/worldclim/; Hijmans et al. 2005) reflecting means, extremes and seasonal variation of temperature and precipitation: Bio1 (mean annual temperature), Bio4 (temperature seasonality), Bio5 (maximum temperature of warmest month), Bio6 (minimum temperature of coldest month), Bio12 (annual precipitation), Bio13 (precipitation of wettest month), Bio14 (precipitation of driest month) and Bio15 (precipitation seasonality). The environmental data were set to a spatial grid resolution of 2.5 arc minutes. We used PCA to summarise variation in altitude and bioclimatic variables between localities and OTUs. Given the steep elevational gradients and the imperfect level of precision implicit in determining geographical coordinates from historical localites using maps and gazetteers, we acknowledge that some degree of caution should be exercised when interpreting these results.

\section{Results}

\section{Cytogenetic data}

At least three distinct karyotypes occur among Ethiopian populations assigned to Otomys "typus" (see also Lavrenchenko et al. 1997). Examples of topotypic O. typus s.s. from the alpine zone of Mount Guna (female: ZMMU 172732), of O. typus fortior from southwestern Ethiopian forests (4 males: ZMMU 164961, 164962, 164965, 181666; two females: ZMMU 164963, 181667), and of Otomys helleri (= "Sp. B") (3 males: ZMMU 162595, 162596, 162601; 3 females: ZMMU 162597, 162599, 162600) from the alpine zone of the Bale Massif share an identical karyotype $(2 \mathrm{~N}=58, \mathrm{NFa}=58)$. The chromosomal complement consists of one pair of small meta- 
centrics (1) and a graded series of 27 pairs of acrocentrics (2-28), ranging in size from large to very small (Fig. 2a). The X-chromosome is a medium-sized acrocentric; the acrocentric Y-chromosome is 3/4 of the length of the Xchromosome. In a single specimen of $O$. helleri "Sp. B" (ZMMU 162601), one autosomal pair was heteromorphic, being represented by a submetacentric and two acrocentrics (see Aniskin et al. 1998).

A karyotype comprising only acrocentric chromosomes $(2 \mathrm{~N}=56, \mathrm{NFa}=54)$, with $\mathrm{X}$ and $\mathrm{Y}$ similar in size to those of Otomys helleri (= "Sp. B"), was found in one individual termed Otomys "Sp. A" (= O. yaldeni sp. nov.; see Taxonomic Summary) (male: ZMMU 162594) from the Bale Massif (Fig. 2b, see also Lavrenchenko et al. 1997).

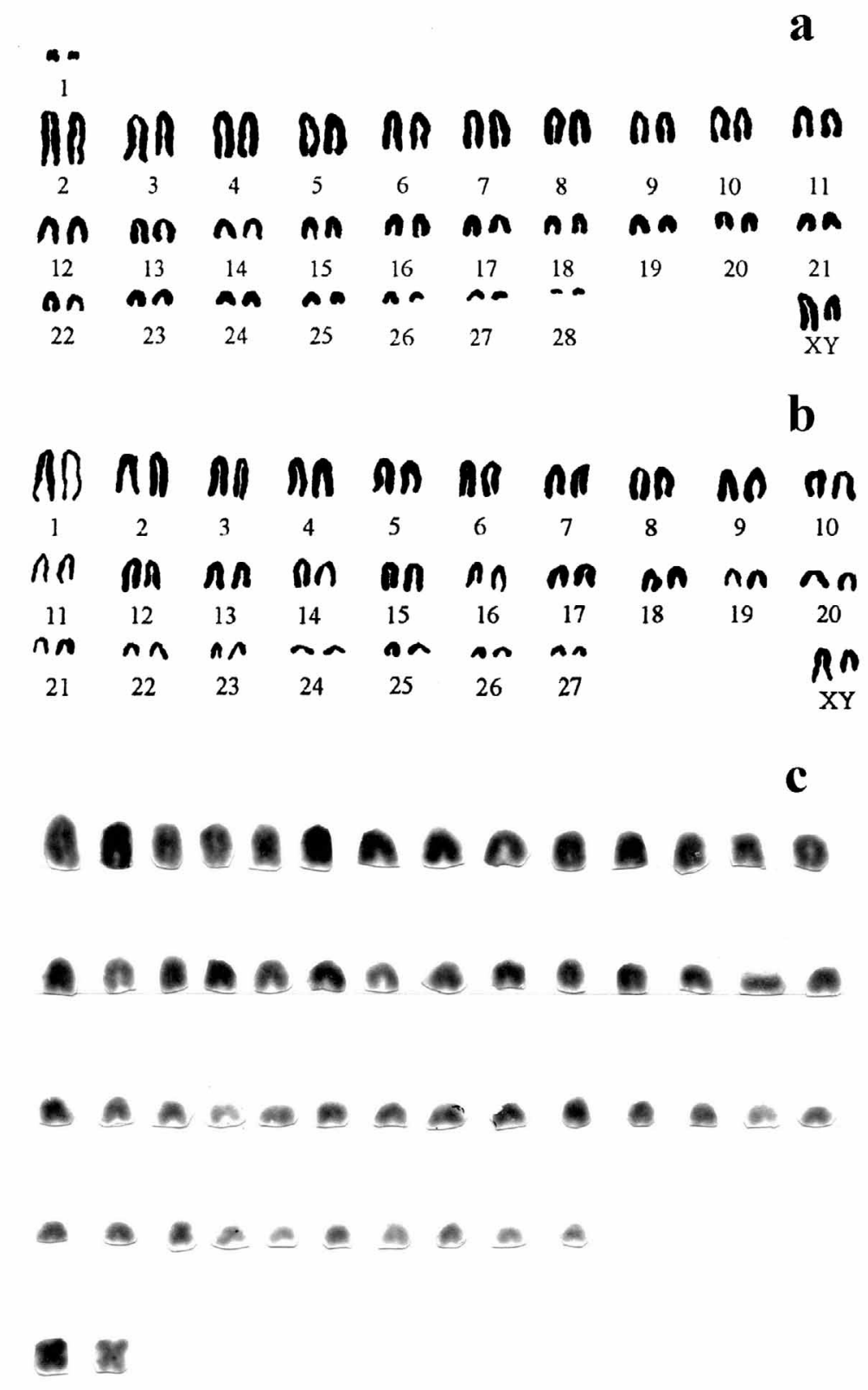

FIGURE 2. Giemsa stained karyotypes of (a) Otomys helleri (= "Sp. B"; n=6), O. fortior $(\mathrm{n}=6)$ and O.typus s.s. $(\mathrm{n}=1)(2 \mathrm{n}=58$, $\mathrm{NFa}=58$ ), (b) Otomys yaldeni sp. nov. (= "Sp. A"; $\mathrm{n}=1 ; 2 \mathrm{n}=56, \mathrm{NFa}=54)$, and (c) Otomys simiensis sp. nov. (= "Sp. D"; $\mathrm{n}=4$; $2 \mathrm{n}=54, \mathrm{NFa}=54)$. 
A third karyotype $(2 \mathrm{~N}=54, \mathrm{NF}=56)$, termed "Sp. D" (= O. simiensis sp. nov.; see Taxonomic Summary), comprising 26 pairs of acrocentrics and one pair of medium-sized metacentrics, was found in four individuals ( 3 males: ZMMU 178757, 178758, 178759; 1 female: ZMMU 178762) from the Simien Mountains (Fig. 2c). The NFa was not determined because the sex chromosomes could not be identified.

\section{Molecular data}

The phylogeny in Fig. 3a reflects the relationships among 44 Otomyini specimens (Appendix 2) as recovered by Bayesian analysis of cyt $b$ sequences (1140 bp). Largely similar topologies resulted from neighbor-joining (NJ, uncorrected $p$ and GTR $+\mathrm{I}+\mathrm{G}$-corrected distances), six-parameter-weighted parsimony (6PP) analysis partitioned by codon position, and maximum likelihood analysis under the best-fit GTR+I+G model (unpartitioned), albeit with varying bootstrap support (bs) for some terminal and deeper relationships (Fig. 3a). Bootstrap support of 70\% and above and Bayesian Posterior Probabilities (BPP) of 0.95 and above are considered significant. The topology strongly supports the monophyly of the Otomyini, renders the East African Otomys lineages paraphyletic and very prominently demonstrates that neither $O$. typus s.l nor $O$. tropicalis s.l. as traditionally understood are monophyletic. Rather, populations assigned to these two nominal species fall into eight well-supported clades, (annotated on Fig. 3a), some with similarly well-supported subclades (BPP: 0.95-1.00; bs: 83\%-100\%). Although these clades form a monophyletic group $(\mathrm{BPP}=0.99)$ with O. occidentalis and O. burtoni from W Africa (Fig. 3a), nodal support for these relationships from ML, parsimony and NJ analyses is statistically insignificant. The eight clades are comprised of the following: Clade 1) an Ethiopian clade whose members conform to the karyotype depicted in Fig. 2a and which taxonomically comprises $O$. typus s.s. (from Mt Guna near the type locality), O. fortior from southwestern forests of Ethiopia, and O. helleri (= "Sp. B") from the Bale Mts of Ethiopia. Within Clade 1, typus s.s. and O. helleri group as well-supported sister taxa $(\mathrm{BPP}=0.98, \mathrm{MLbs}=83 \%)$, but weak genetic distances (Table 3) and absence of statistical nodal support characterize their interrelationships with $O$. fortior from the southwestern Beletta and Inegawa forests (nodes 1c-1e); Clade 2) a taxonomically enigmatic clade (seemingly defined by smallsized individuals; see Morphometrics below). This clade comprises an individual (RMCA a6.016-M-2034) of $O$. tropicalis faradjius from Rethy, DRC; an individual (RMCA a1.008-M-1122) of "O. tropicalis tropicalis" from the moorlands of the Aberdares, and two individuals (DM 6282, USNM 590005) of O. tropicalis elgonis from Mt Elgon. Within this clade, the Aberdares specimen groups closely [ $p=1.4 \%]$ with the $O$. $t$. elgonis individuals (node $2 \mathrm{~b}$ ), while the DRC specimen is rather more distant [ $p=3.2 \%$; Clade 3) a clade consisting of two well-supported subclades a) O. orestes from the Aberdares Mts (USNM 5989997 and RMCA a1.008-M-1123), and b) two outlying O. tropicalis" elgonis" individuals (USNM 590004 and 590006) from the sub-alpine bamboo zone of Mt Elgon. A third subclade c) constitutes $O$. jacksoni from the alpine zone of Mt Elgon of which the sister taxon affiliation is unresolved; Clade 4) an individual (RMCA a6.013-M-2031) from the Usambara Mts assigned morphologically to O. sungae on cranial and pelage characters (Usambara Mts are also the topotypic source of sungae); Clade 5) chromosomally-defined $O$. simiensis sp. nov. (= "Sp. D") from the Simien Mts of Ethiopia; Clade 6) O. zinki from Mt Kilimanjaro; Clade 7) O. dartmouthi from the Albertine Rift (Ruwenzori Mts); Clade 8) O. tropicalis s.s, comprising well-supported subclades (separated by distances of around 3\%) from Mt Kenya (type locality) and the Aberdares.

TABLE 3. Estimates of mean divergence between Ethiopian Otomys taxa given as average uncorrected $p$-distances for cyt $b$ (below the diagonal; with standard errors based on 10000 bootstrap replicates given in parentheses). Observed values (average uncorrected $p$-distances followed by standard errors) of intra-taxon sequence variation are given along the diagonal; $\mathrm{n}=\mathrm{num}$ ber of sequences within each taxon.

\begin{tabular}{lllll}
\hline & $1(\mathrm{n}=1)$ & $2(\mathrm{n}=5)$ & $3(\mathrm{n}=2)$ & $4(\mathrm{n}=4)$ \\
\hline (1) O. typus $(\mathrm{n}=1)$ & - & & & \\
(2) O. fortior $(\mathrm{n}=5)$ & $0.0343(0.0090)$ & $0.0056(0.0017)$ & & \\
(3) O. helleri (= “Sp. B”) $(\mathrm{n}=2)$ & $0.0323(0.0089)$ & $0.0229(0.0073)$ & $0.0050(0.0033)$ & \\
(4) O. simiensis sp. nov. (= “Sp. D”) $(\mathrm{n}=4)$ & $0.1045(0.0160)$ & $0.0880(0.0089)$ & $0.0871(0.0139)$ & $0.0000(0.0000)$ \\
\hline
\end{tabular}


Poor support for deeper levels of the cyt $b$ phylogeny obscure cladistic relationships of the well-supported eastern African clades to other Otomyini taxa from West Africa (O. occidentalis and O. burtoni) and southern Africa (O. irroratus, $O$. angoniensis and P. brantsii) as well as among lineages within each of these regions. Populations once assigned to $O$. sungae s.l. are widely divergent: the topotypic Usambaras population groups closest to $O$. orestes in the eastern African typus-tropicalis s.l. clade, whereas the geographically distant population from the Nyika Plateau, Malawi, a putative new species (FMNH 191809), groups within a strongly supported O. lacustris clade from the Eastern Arc Mts (FMNH 155623) and the "Southern Rift" (RMCA 96.037-M-5237) sensu Taylor $e t$ al. (2009a). The relationships of $O$. denti denti from the Albertine Rift remain uncertain.

Large cyt $b$ genetic distances characterise those taxa formerly assigned to Otomys typus by Bohmann (1952) and Misonne (1975). The Mt Kilimanjaro population (O. zinki) herein, elevated to full species status, forms a wellsupported clade separated from all other Otomys specimens by uncorrected cyt $b$ distances of 6.6-13.6\%. Although based on fewer specimens, large genetic distances also characterize specimens referred to $O$. dartmouthi (6.6$12.7 \%)$, O. orestes (4.6-13.0\%), and O. jacksoni (7.3-12.9\%). According to the cyt $b$ data, each of these four taxa has cladistic affinity to different Kenyan samples currently assigned to $O$. tropicalis s.1., not to those from Ethiopia (O. typus s.s., O. fortior, O. helleri (= “Sp. B”), O. simiensis sp. nov. (= “Sp. D”)). Divergence dates obtained for the major clades from Bayesian approximation in BEAST using cyt $b$ data partitioned by codon positions are shown in Fig. 3a and discussed further below.

Bayesian, maximum likelihood, parsimony and NJ analyses of combined 12S rRNA and cyt $b$ sequences for a reduced taxon sample of Otomys $(\mathrm{n}=20)$ and Parotomys brantsii $(\mathrm{n}=1)$ proved valuable for clarifying some deeper level associations among eastern, western and southern African lineages (Fig. 3b). Notwithstanding the unresolved position of $O$. barbouri (Mt Elgon) and Parotomys brantsii (South Africa) in the Otomyini clade, two well-supported main clades emerged. The first (Clade 1; node 6), exclusively eastern African clade unites $O$. denti denti (Albertine Rift; FMNH 157807), the putative new species from the Nyika Plateau (FMNH 191809) and O. lacustris (Eastern Arc Mts and "Southern Rift"). The second well-supported main clade (defined by node 10 in Fig. 3b) contains southern, western and eastern African lineages (Clade 2). Herein, the sister taxon affiliations of the South African $O$. irroratus and $O$. angoniensis and $O$. fortior (Beletta Forest, Jimma, Ethiopia, part of cyt $b$ clade 1) remain unresolved, but $O$. occidentalis from western Africa is supported (on Bayesian probabilities although not consistently with bootstrap support) as the sister taxon of a larger clade comprising two unresolved taxa (O. zinki and $O$. dartmouthi) and two well supported subclades: a) constituting two distinct and well supported lineages, one involving $O$. jacksoni, the divergent $O$. tropicalis “elgonis" lineage (Mt Elgon) and O. orestes from Aberdares NP (part of cyt $b$ clade 3 subclades a, b, and c), and the second comprising O. t. elgonis from Mt Elgon (part of cyt $b$ clade 2 in Fig. 3a); b) a well-supported clade confirming the monophyly of $O$. tropicalis s.s.from the Aberdares (moorlands) and Mt Kenya (cyt $b$ clade 8). 
a) BPP/ MLbs/ UwPbs/6PPbs/ Njpbs/ NJcbs

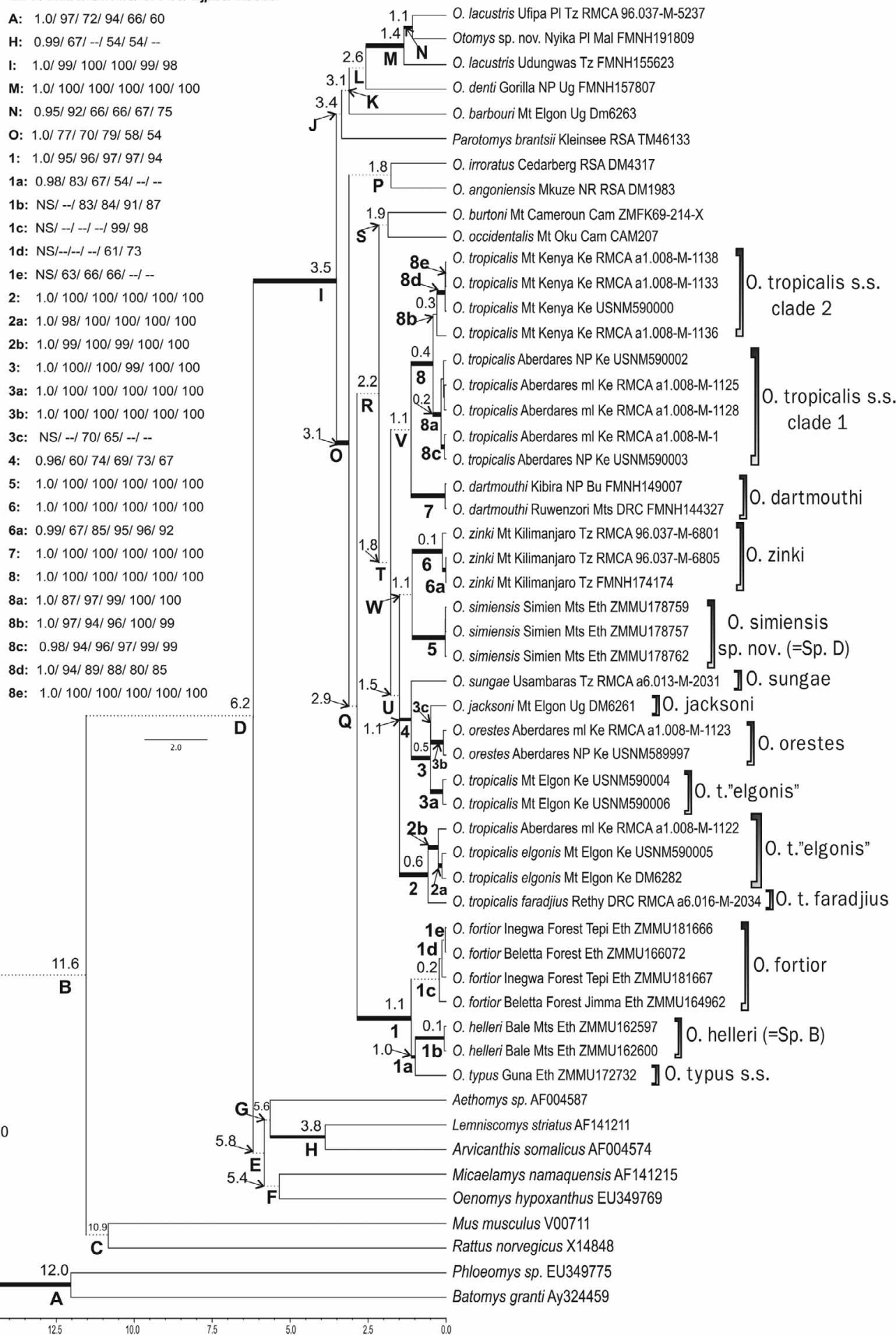

FIGURE 3a. Bayesian phylogeny inferred from cyt $b$ sequences partitioned by codon position for 34 East African specimens of $O$. typus s.l. and $O$. tropicalis s.l. in relation to representatives of seven Otomys species and Parotomys brantsii from eastern, western and southern Africa. Representatives of nine murine taxa served as outgroups (see Appendix 1). Nodal support indices for the main clades (annotated 1 to 8 ) and subclades (a, b, c, d and e), as well as supported deeper nodes (A, H, I, M, N, O) are given beside the phylogram in the following order: Bayesian posterior probabilities (BPP)/ bootstrap support from 1000 replicates for maximum likelihood (MLbs), under an unpartitioned GTR+I+G model/ unweighted parsimony (UwPbs), six-parameter-weighted parsimony partitioned by codon positions (6PPbs)/ neighbour-joining using uncorrected $p$-distances (Njpbs)/ neighbour-joining using GTR+I+G-corrected distances (Njcbs). Estimated divergence dates (Myr) for the major lineages identified in the cyt $b$ phylogeny are indicated to the left of each node. Bayesian estimation of divergence times was conducted under a relaxed clock model using BEAST v.1.4. Four well established murine fossil calibration points were specified (Pocock 1987; Rowe et al. 2008, see text). 
Mus musculus V00711

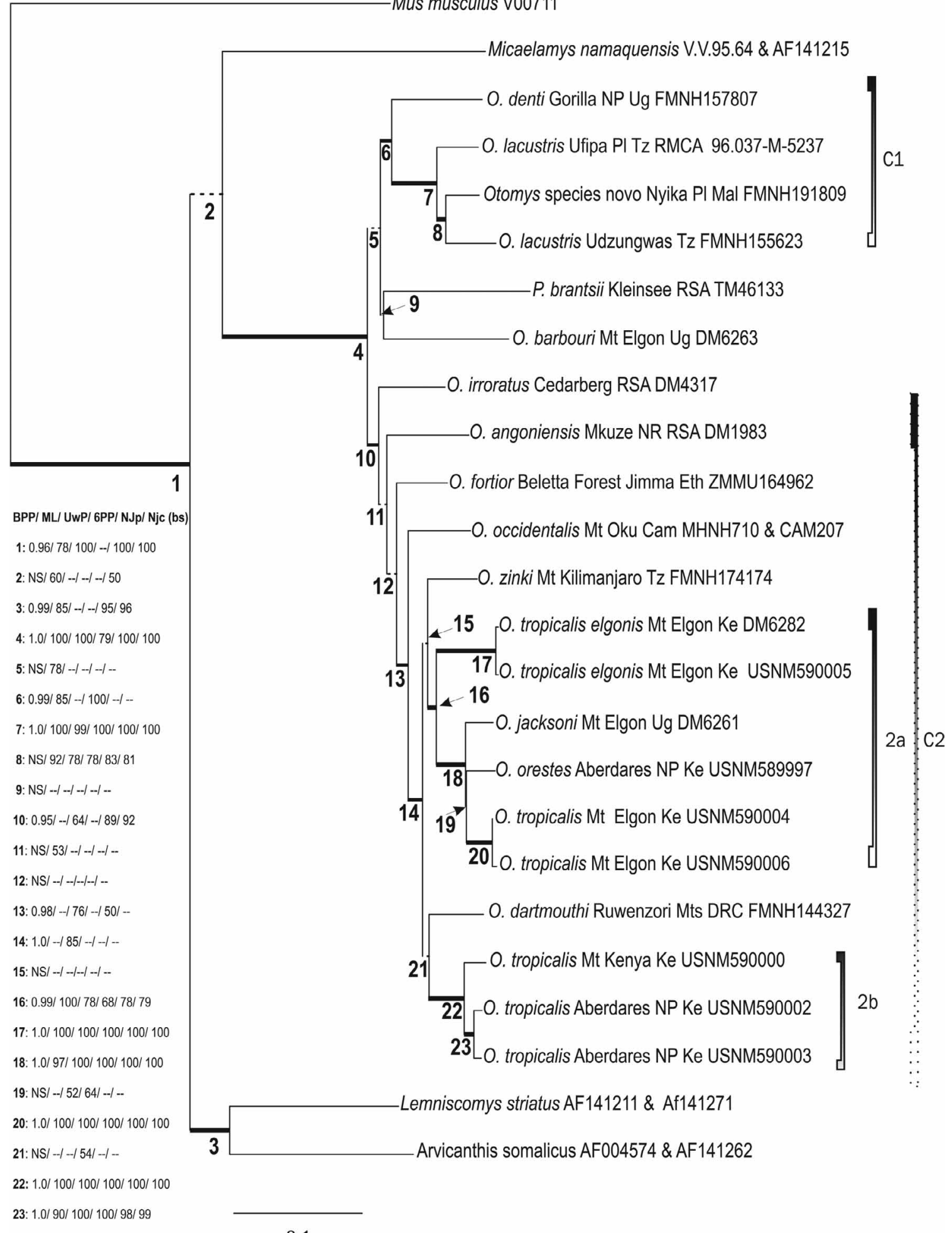

0.1

FIGURE 3b. Maximum likelihood phylogram constructed from combined cyt $b$ and $12 \mathrm{~S}$ rRNA sequences for 20 Otomys specimens, one representative of Parotomys brantsii and four murine outgroups under the best-fit GTR+I+G model. Support indices for each node $(1-23)$ are given beside the phylogram (BPP/ MLbs/ UwPbs/6PPbs/ NJpbs/ Njcbs). For both phylogenies (Figure $3 \mathrm{a}$ and $3 \mathrm{~b}$ ), the relative branch thickness indicates significant nodal support from the phylogenetic reconstruction methods employed herein (four to six methods-thick lines; two methods-intermediate lines). Dashed lines show unsupported relationships; Abbreviations and symbols: NS - BPP < 0.95; ““_" indicates that the node was not present in the relevant analysis, or percentage bootstrap support below $50 \%$. 


\section{Craniodental characters}

Of the five characters traditionally used to define species and supra-specific groupings in Otomys, two (number of m1 laminae and shape of petrotympanic foramen) are typically invariant intraspecifically whilst the other three tend to be highly variable both within and between taxa historically assigned to typus s.1. or tropicalis s.1. (Table 4). A population of tropicalis from the summit of the Aberdares, Kenya, is exceptional in possessing five well defined m1 laminae in six out of ten specimens (another three contained an incipient fifth lamina), a character state otherwise not found in any other east African Otomys populations except for O. barbouri from Mt Elgon (Kenya/ Uganda border) and O. lacustris from the Southern Highlands and Eastern Arc Range of Tanzania (Table 4). Additional specimens from Aberdares possess five $\mathrm{m} 1$ laminae, including one generally labeled "Aberdares" (BM 10.5.3.480), one from Mt Kinangop, Aberdares (MNHN1913_216A), and a third from Aberdare National Park Fishing Lodge (USNM 590014).

Modal numbers of the OTU samples are instructive for the more variable craniodental characters. Thus in OTUs representing tropicalis s.l., the angle of anterior expansion of the nasal bones is typically $>120^{\circ}$, whilst in the alpine forms representing typus s.l. (O. dartmouthi, O. jacksoni, O. orestes, O. thomasi, O. typus s.s., O. uzungwensis and $O$. zinki), the modal angle is $<100^{\circ}$. The presence of two equally deep grooves on the lower incisors characterizes all forms from Ethiopia (O. typus s.s., O. fortior, O. yaldeni sp. nov. (= “Sp. A”), O. helleri (= “Sp. B”), O. cheesmani sp. nov. (= "Sp. C"), O. simiensis sp. nov. (= "Sp. D”)) and the alpine taxa from the Ruwenzoris (dartmouthi), Mt Elgon (jacksoni) and the Tanzanian Highlands (uzungwensis); in contrast, alpine forms from the Kenyan Highlands (orestes and thomasi) and Mt Kilimanjaro (zinki) possess one deep and one shallow groove, with the exception of the type specimens of malleus and squalus from the Aberdares which have two deep grooves. Strangely, two deep grooves in i1 characterize two individuals from O. tropicalis elgonis from Mt Elgon, including the holotype of elgonis. Discrete craniodental characters provide a reliable means to distinguish certain forms previously grouped as synonyms within $O$. typus; e.g., the M3 of dartmouthi individuals consistently comprise only six laminae $(\mathrm{n}=13)$, individuals of uzungwensis $(\mathrm{n}=19)$ and jacksoni $(\mathrm{n}=3)$ comprise seven, whereas those from Ethiopia are much more variable, usually comprising eight or more (47 of 50 individuals scored). Interestingly, the Ethiopian populations of the chromosomally defined $O$. yaldeni sp. nov. (= "Sp. A") and $O$. simiensis sp. nov. (= "Sp. D") possess a modal number of seven laminae as opposed to eight in other populations from Ethiopia (Table 4).

TABLE 4A. Variation in the nasal angle and development of lower incisor grooves in OTUs of Otomys from eastern Africa. See text for explanation of character states.

\begin{tabular}{|c|c|c|c|c|c|c|c|c|c|}
\hline \multirow[b]{2}{*}{ Taxon and OTU } & \multirow[b]{2}{*}{$N$} & \multicolumn{3}{|c|}{ Nasal angle } & \multicolumn{5}{|c|}{ Lower incisor grooves } \\
\hline & & $90-99^{\circ}$ & $100-119^{\circ}$ & $120-149^{\circ}$ & $>150^{\circ}$ & 1 & $1+\mathrm{t}$ & $1+\mathrm{s}$ & 2 \\
\hline \multicolumn{10}{|c|}{$\begin{array}{l}\text { O. typus s.1. (Cytotype 1) } \\
\text { (incl. fortior + "Sp. B" + "Sp. C") }\end{array}$} \\
\hline OTU 1-4 (Ethiopia) & 50 & 18 & 5 & - & - & - & - & - & 50 \\
\hline $\begin{array}{l}\text { O. typus s.1. (Cytotypes 2, 3) } \\
\text { (incl. "Sp. A" + "Sp. D") } \\
\text { OTU 5-7 (Ethiopia) }\end{array}$ & 9 & 3 & 3 & - & - & - & - & - & 9 \\
\hline
\end{tabular}


TABLE 4A. (continued)

\begin{tabular}{|c|c|c|c|c|c|c|c|}
\hline & & Nasal angle & & & Lower incisc & ooves & \\
\hline Taxon and OTU & $N$ & $90-99^{\circ} \quad 100-119^{\circ}$ & $120-149^{\circ}$ & $>150^{\circ}$ & $1 \quad 1+t$ & $1+\mathrm{s}$ & 2 \\
\hline
\end{tabular}

O. typus s.l.

OTU 7 (un-assigned localities)

Chilalo

Chenca

Bongke

Jimma

Ankober

Hirna

Arussi Plateau

$\begin{array}{lllllllll}6 & 5 & 1 & - & - & - & - & - & 6 \\ 10 & 10 & - & - & - & - & - & - & 7 \\ 2 & 2 & - & - & - & - & - & - & - \\ 8 & 8 & - & - & - & - & - & - & 2 \\ 1 & 1 & - & - & - & - & - & - & 1 \\ 2 & - & - & - & - & - & - & - & 2 \\ 6 & 2 & - & - & - & - & - & - & 2\end{array}$

O. tropicalis

OTU 8 (Aberdares)

OTU 9 (Mt Kenya)

OTU 10 (Mt Elgon)

OTU 11 (Aberdares Summit)

$\begin{array}{lllllllll}11 & 2 & 1 & 7 & - & - & - & 8 & 0 \\ 22 & 4 & 4 & 11 & 3 & 5 & 3 & 10 & - \\ 15 & - & 4 & 11 & - & - & 1 & 11 & 2 \\ 10 & 9 & 1 & - & - & 5 & 2 & 3 & -\end{array}$

O. zinki

OTU 12 (Mt Kilimanjaro)

$9 \quad 6 \quad 3$

O. orestes

OTU 13 (Mt Kenya \&

Aberdares)

$14 \quad 7$

O. thomasi

OTU 14 (Mau Escarpment)

O. dartmouthi

OTU 15 (Ruwenzoris)

O. uzungwensis

OTU 16 (Eastern Arc)

$19 \quad 14$

O. jacksoni

OTU (Mt Elgon)

O. barbouri

OTU 18 (Mt Elgon)

O. lacustris

OTU 19 (Eastern Arc)

O. sungae

OTU 20 (Usambaras)

$\begin{array}{lll}13 & 5 & 4\end{array}$

$-$

3

$14 \quad 12$

2322

$11 \quad 8$

$21 \quad 2$

$15-2 \quad 2 \quad 5$

$-\quad 9$

9

5

TABLE 4B. Number of laminae in the upper third molar (M3) and lower first molar (m1) in OTUs of Otomys from eastern Africa. See text for explanation of character states.

\begin{tabular}{lcccccccc}
\hline & \multicolumn{3}{c}{ M3 laminae } & \multicolumn{3}{c}{ m1 laminae } \\
Taxon and OTU & $N$ & 6 & 7 & 8 & 9 & 4 & $4+1$ & 5 \\
\hline $\begin{array}{l}\text { O. typus s.1. (Cytotype 1) } \\
\text { (incl. fortior + "Sp. B" + "Sp. C") }\end{array}$ & 50 & - & 3 & 35 & 12 & 50 & - & - \\
OTU 1-4 (Ethiopia) & & & & & & & \\
\hline
\end{tabular}


TABLE 4B. (continued)

\begin{tabular}{|c|c|c|c|c|c|c|c|c|}
\hline \multirow[b]{2}{*}{ Taxon and OTU } & \multirow[b]{2}{*}{$N$} & \multicolumn{3}{|c|}{ M3 laminae } & \multirow[b]{2}{*}{9} & \multicolumn{2}{|c|}{ m1 laminae } & \multirow[b]{2}{*}{5} \\
\hline & & 6 & 7 & 8 & & 4 & $4+1$ & \\
\hline $\begin{array}{l}\text { O. typus s.1. (Cytotypes 2, 3) } \\
\text { (incl. "Sp. A" + “Sp. D") } \\
\text { OTU 5-6 (Ethiopia) }\end{array}$ & 9 & 1 & 8 & - & - & 9 & - & - \\
\hline \multicolumn{9}{|l|}{ O. typus s.l. } \\
\hline Chilalo & 6 & - & 1 & 5 & - & 6 & - & - \\
\hline Chenca & 10 & - & 1 & 5 & 4 & 3 & - & - \\
\hline Bongke & 2 & - & - & 2 & - & 2 & - & - \\
\hline Jimma & 8 & - & - & 8 & - & 8 & - & - \\
\hline Ankober & 1 & - & 1 & - & - & 1 & - & - \\
\hline Hirna & 2 & - & 1 & 1 & - & 2 & - & - \\
\hline Arussi Plateau & 6 & - & - & 5 & 1 & 3 & - & - \\
\hline \multicolumn{9}{|l|}{ O. tropicalis } \\
\hline OTU 8 (Aberdares) & 11 & - & 9 & 2 & - & 10 & - & - \\
\hline OTU 9 (Mt Kenya) & 22 & 2 & 18 & 2 & - & 22 & - & - \\
\hline OTU 10 (Mt Elgon) & 15 & 2 & 13 & - & - & 15 & - & - \\
\hline OTU 11 (Aberdares Summit) & 10 & - & 8 & 2 & - & 1 & 3 & 6 \\
\hline \multicolumn{9}{|l|}{ O. zinki } \\
\hline OTU 12 (Mt Kilimanjaro) & 9 & - & 9 & - & - & 8 & - & - \\
\hline \multicolumn{9}{|l|}{ O. orestes } \\
\hline $\begin{array}{l}\text { OTU } 13 \text { (Mt Kenya \& } \\
\text { Aberdares) }\end{array}$ & 14 & 2 & 11 & - & - & 13 & - & - \\
\hline $\begin{array}{l}\text { O. thomasi } \\
\text { OTU } 14 \text { (Mau Escarpment) }\end{array}$ & 5 & - & 4 & 1 & - & 5 & - & - \\
\hline $\begin{array}{l}\text { O. dartmouthi } \\
\text { OTU } 15 \text { (Ruwenzoris) }\end{array}$ & 13 & 13 & - & - & - & 13 & - & - \\
\hline $\begin{array}{l}\text { O. uzungwensis } \\
\text { OTU } 16 \text { (Eastern Arc) }\end{array}$ & 19 & - & 19 & - & - & 19 & - & - \\
\hline $\begin{array}{l}\text { O. jacksoni } \\
\text { OTU (Mt Elgon) }\end{array}$ & 3 & - & 3 & - & - & 3 & - & - \\
\hline $\begin{array}{l}\text { O. barbouri } \\
\text { OTU } 18 \text { (Mt Elgon) }\end{array}$ & 14 & - & 12 & 2 & - & 1 & - & 13 \\
\hline $\begin{array}{l}\text { O. lacustris } \\
\text { OTU } 19 \text { (Eastern Arc) }\end{array}$ & 23 & 3 & 19 & 1 & - & 1 & 2 & 20 \\
\hline $\begin{array}{l}\text { O. sungae } \\
\text { OTU } 20 \text { (Usambaras) }\end{array}$ & 15 & 3 & 7 & - & - & 9 & 5 & - \\
\hline
\end{tabular}

\section{Morphometric data}

Non-geographic variation. On average, males have slightly larger crania than females in all linear variables, but this was only significant (and only at the 5\% level) in the case of anterior palatal length and maxillary toothrow (Table 5). Age classes differed significantly in linear and shape variables (Table 5; Fig. 4). Only one variable, inter- 
orbital constriction showed absence of significant ontogenetic variation, with mean values increasing from toothwear class 2 to class 3 and then decreasing in class 4 individuals (Table 5). In other variables, toothwear class explained between $42 \%$ and $86 \%$ of total variance; in six variables, all means differed significantly from each other, whilst in three, toothwear classes 3 and 4 formed homogeneous subsets. By comparison, sex explained only between $0.3 \%$ and $9 \%$ of the total variance. Multivariate analysis of variance (MANOVA) of the weights matrix from dorsal landmarks revealed significant differences between age classes 3 and 4 at the 5\% probability level (Wilks lambda $=0.129$, d.f. $=18,9 ; \mathrm{p}=0.03$ ). MANOVA of a pooled sample of age classes 3 and 4 individuals from Tora revealed lack of significant sexual dimorphism in shape (Wilks lambda $=0.106$, d.f. $=18,6 ; p>0.05$ ). Based on these results, further analyses combined the sexes, but were restricted to toothwear class 4 and 5 individuals (the latter refer to very old individuals with heavily worn teeth, which are very rare in collections), except in the case of types or other critical specimens where occasionally toothwear class 3 individuals were included.

TABLE 5. Means and two-way ANOVAs of craniometric variables for age classes $2-4$ of male $(N=19)$ and female $(N=20)$ Otomys tropicalis from Tora, Burundi.

\begin{tabular}{|c|c|c|c|c|c|c|c|c|c|c|}
\hline \multirow{3}{*}{$\begin{array}{l}\text { Variable } \\
\text { GLS }\end{array}$} & \multicolumn{3}{|c|}{ Age Class $(N)$ : Male } & \multicolumn{3}{|c|}{ Age Class $(N)$ : Female } & \multirow{2}{*}{$\begin{array}{l}\% S S ; F \\
\text { Sex }\end{array}$} & \multirow[b]{2}{*}{ Age } & \multirow[b]{2}{*}{ Sex $\times$ Age } & \multirow{2}{*}{$\begin{array}{l}\text { Age Subsets } \\
\text { (Tukey HSD) }\end{array}$} \\
\hline & $2(2)$ & $3(10)$ & $4(7)$ & 2(2) & $3(7)$ & & & & & \\
\hline & 30.3 & 38.2 & 41.0 & 30.5 & 37.7 & 40.2 & $0.7 ; 1.7$ & $85.6 ; 105.0^{* *}$ & $0.2 ; 0.2$ & AS \\
\hline $\mathrm{BCD}$ & 9.6 & 11.1 & 11.7 & 9.8 & 11.0 & 11.2 & $2.2 ; 1.6$ & $49.8 ; 18.1^{* *}$ & $2.4 ; 0.9$ & $(2):(3-4)$ \\
\hline GLM & 20.0 & 23.9 & 25.9 & 20.0 & 23.4 & 25.2 & $2.0 ; 3.5$ & $79.0 ; 69.6^{* *}$ & $0.3 ; 0.3$ & AS \\
\hline APF & 4.8 & 6.5 & 7.3 & 4.9 & 6.3 & 6.7 & $4.4 ; 4.8^{*}$ & $64.6 ; 37.1^{* *}$ & $2.2 ; 1.2$ & AS \\
\hline MXTRL & 8.3 & 9.3 & 9.4 & 8.5 & 9.0 & 9.1 & $8.9 ; 5.8^{*}$ & $42.2 ; 15.1^{* *}$ & $3.5 ; 1.2$ & $(2):(3-4)$ \\
\hline NAW & 5.6 & 6.8 & 7.4 & 5.5 & 6.7 & 7.3 & $0.6 ; 1.1$ & $80.6 ; 70.6^{* *}$ & $0.0 ; 0.1$ & AS \\
\hline IOC & 4.5 & 4.6 & 4.5 & 4.4 & 4.5 & 4.5 & $3.5 ; 1.3$ & $1.7 ; 0.3$ & $0.3 ; 0.1$ & NS \\
\hline ZYW & 13.7 & 18.1 & 19.3 & 15.6 & 18.2 & 19.3 & $0.5 ; 0.8$ & $77.5 ; 68.0^{* *}$ & $3.2 ; 2.8$ & AS \\
\hline PL & 15.6 & 19.8 & 21.5 & 16.2 & 19.7 & 21.1 & $0.3 ; 0.7$ & $84.7 ; 97.4^{* *}$ & $0.8 ; 0.9$ & AS \\
\hline BL & 6.5 & 7.5 & 7.7 & 6.5 & 7.4 & 7.5 & $2.2 ; 1.8$ & $56.2 ; 22.6^{* *}$ & $0.6 ; 0.2$ & $(2):(3-4)$ \\
\hline
\end{tabular}

${ }^{*}=\mathrm{P} \leq 0.05 ;{ }^{* *}=\mathrm{P} \leq 0.01 ; \mathrm{AS}=$ All pair-wise comparisons significantly different; $\mathrm{NS}=$ Not significant.

Geographic and taxonomic variation. Ethiopian sample. Based on combined cytogenetic, molecular, dental and craniometric data (Lavrenchenko 1997, unpublished; Figs. 2, 3, 5-7), we propose the existence of six Otomys lineages in Ethiopia (represented by OTUs 1-6 in Fig. 1, Tables 2 and 4). Unassigned populations (from additional Museum collections) were arbitrarily assigned to OTU 7. Figure 5 shows the results of PCA of nine craniometric variables of specimens from the six hypothesized taxa. Specimens from Dangila (near Lake Tana) and Debra Marcos ("Sp. C"; described as O. cheesmani sp. nov. under Taxonomic Summary) are clearly distinguished by their larger cranial size (higher non-overlapping scores on PC1; Fig 5 and Table 6). Specimens belonging to the distinct chromosomal forms "Sp. A" (from Bale Mts; described as O. yaldeni sp. nov. under Taxonomic Summary) and “Sp. D” (Simien Mts; described as O. simiensis sp. nov. under Taxonomic Summary) are distinguished by their smaller size (low scores on PC 1; Fig. 5 and Table 6); they are further distinguished from each other by shape characteristics (PC2 versus PC3: Fig. 5b) whereby O. simiensis sp. nov (= "Sp. D”) (OTU 6) has lower scores on PC2 and PC3 representing a narrower interorbital constriction and shallower braincase (Table 6), than O. yaldeni sp. nov. (= "Sp. A") (OTU 5). These same shape dimensions distinguish populations from the southwestern forests (Charada, Sheko, Beletta) of Ethiopia (encompassing the form fortior) from those from the alpine zone of the Bale Massif ("Sp. B" or O. helleri; see discussion below) (Fig. 5b) whereby the former have a narrower interorbital constriction and shallower braincase. Topotypic specimens from the alpine zone of the Simien Mts and Mt Guna (typus s.s.) are intermediate in shape between those of fortior (including the type specimen marked with asterisk in Fig. 5) and $O$. helleri (= "Sp. B"). The position of the type specimen of degeni from Gombitchu in central Ethiopia (not far from the capital of Addis Ababa) on the PCA plots is somewhat peripheral to other Ethiopian specimens but not clearly distinct (Fig. 5). No other specimens attributable to this taxon were available for analysis. 

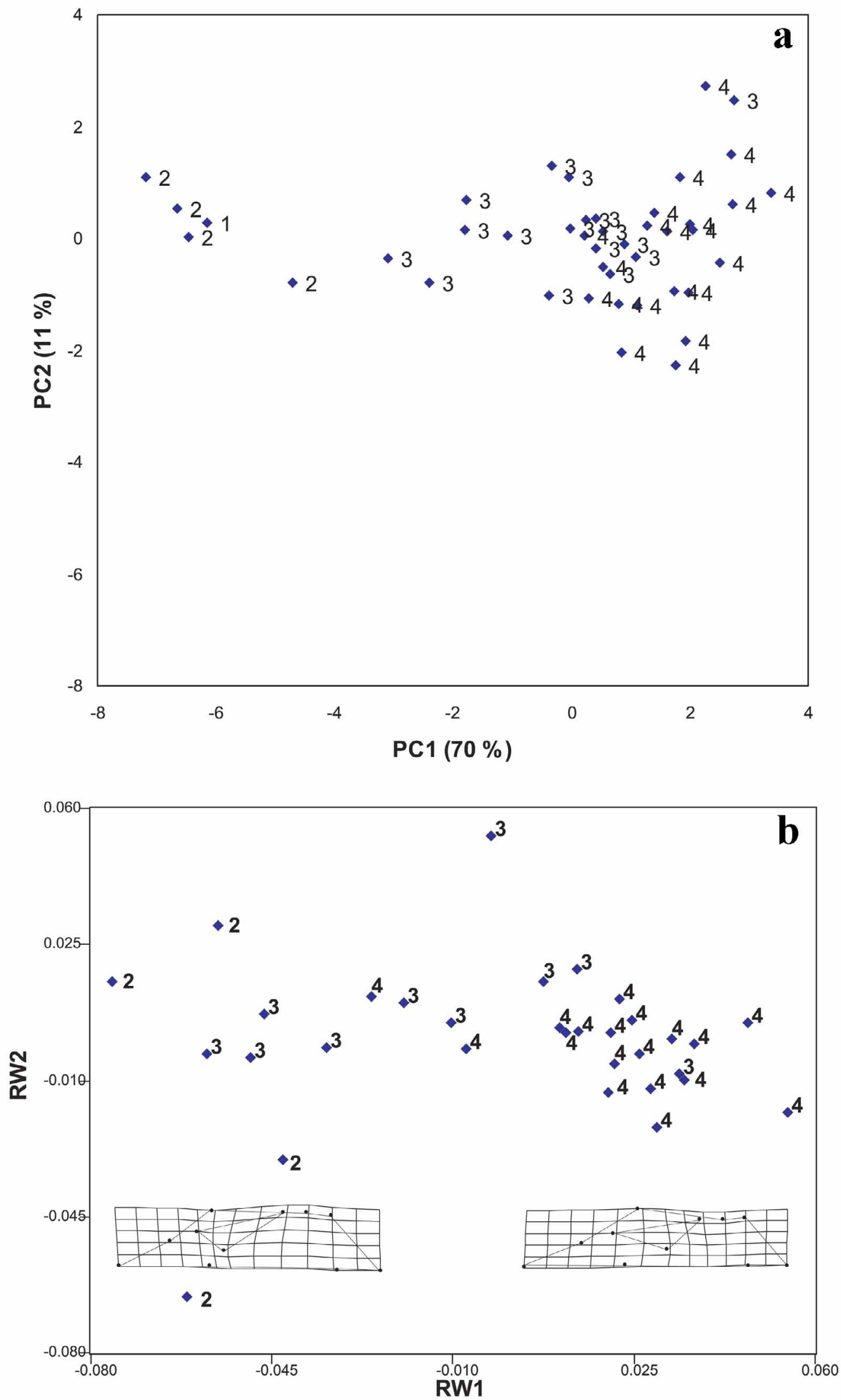

FIGURE 4. Principal component analysis (PCA) of nine linear craniometric variables (a) and relative warps analysis (RWA) of dorsal landmarks (b) showing dispersion of relative age classes in one population of $O$. tropicalis from Tora, Burundi. 


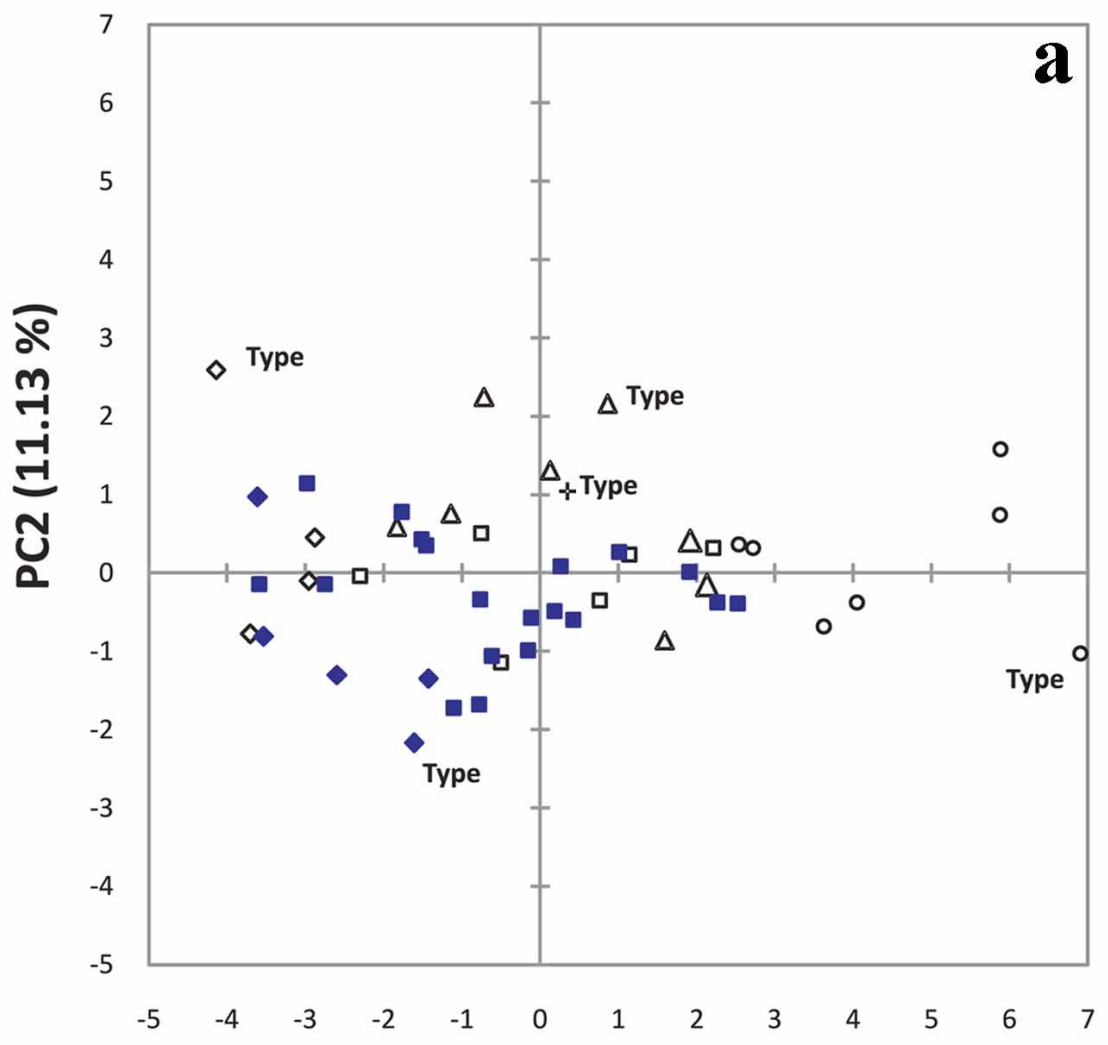

PC1 (73.5 \%)

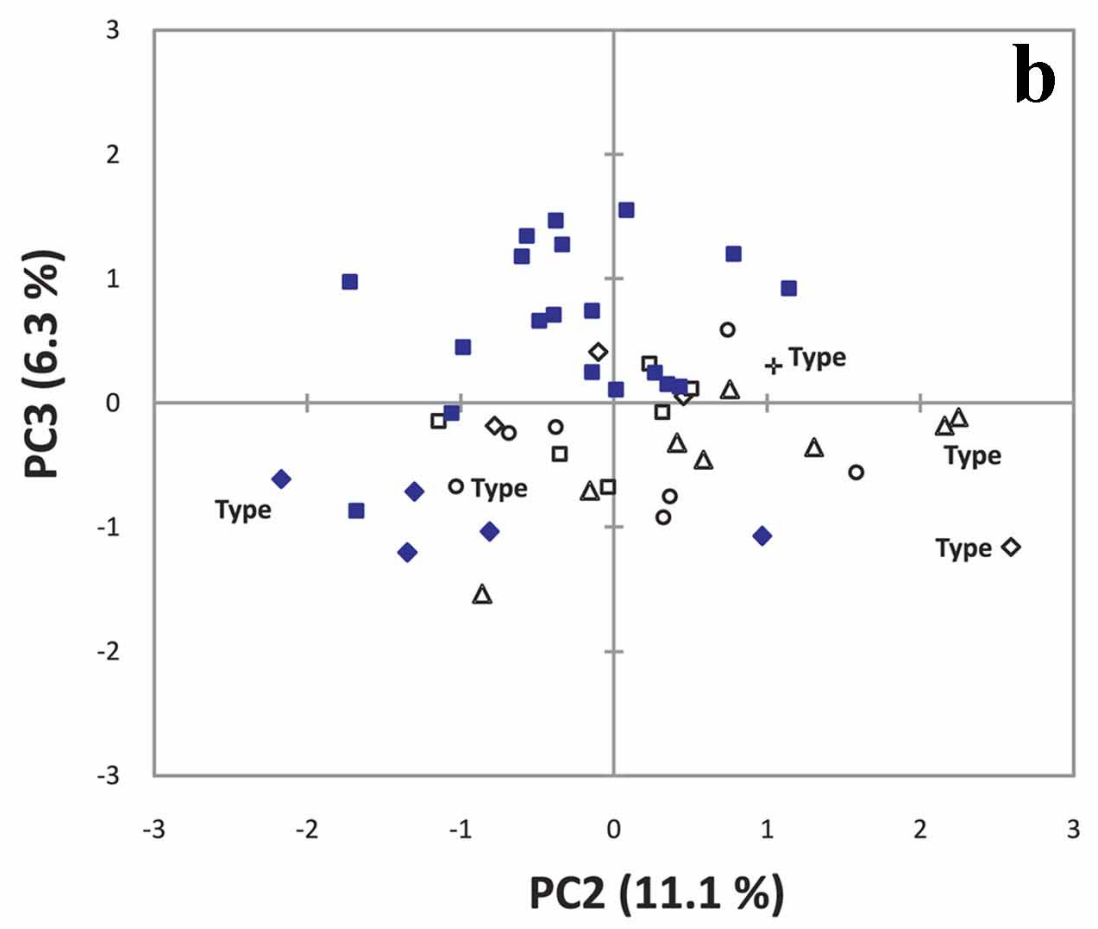

FIGURE 5. Principal components analysis (PCA) based on nine craniometric variables indicating scatter of individuals on PC1 and PC2 (a) and PC2 and PC3 (b) from six pre-defined taxon-groups of Ethiopian Otomys in relation to existing type specimens of fortior and degeni and new holotypes designated for new species (see Taxonomic Summary). Open squares $=O$. typus s.s., open triangles $=O$. fortior ; open diamonds $=$ O. yaldeni sp. nov. $(=\mathrm{Sp} . \mathrm{A})$; closed squares $=$ O. helleri $(=\mathrm{Sp} . \mathrm{B}) ;$ open circles $=$ $O$. cheesmani sp. nov. (= Sp.C); closed diamonds =O. simiensis sp. nov. $(=$ Sp. D); cross = degeni . Type specimens indicated; normal font indicates existing holotypes; bold font represents newly designated holotypes (see Taxonomic Summary). 
TABLE 6. Eigenvectors (PCA) and Canonical Variates Analysis (CVA) of linear craniometric data from different data subsets of the $O$. typus species complex.

\begin{tabular}{|c|c|c|c|c|c|c|c|c|c|}
\hline \multicolumn{6}{|c|}{ Ethiopian Highlands (Fig. 5, 6) } & \multicolumn{2}{|c|}{$\begin{array}{l}\text { Kenyan Highlands } \\
\text { (Fig. 8a) }\end{array}$} & \multicolumn{2}{|c|}{$\begin{array}{l}O . \text { orestes versus } O \text {. } \\
\text { thomasi }(\text { Fig. } 8 \mathrm{~b})\end{array}$} \\
\hline & PC1 & PC2 & PC3 & CV1 & CV2 & PC1 & PC2 & PC1 & PC2 \\
\hline GLS & 0.374 & -0.092 & -0.259 & 0.849 & 0.035 & 0.454 & 0.038 & 0.498 & -0.165 \\
\hline $\mathrm{BCD}$ & 0.300 & 0.048 & 0.684 & 0.603 & 0.499 & 0.266 & -0.433 & 0.067 & 0.669 \\
\hline APF & 0.363 & 0.088 & 0.080 & 0.771 & 0.112 & 0.390 & -0.147 & 0.421 & 0.117 \\
\hline MXTRL & 0.355 & 0.016 & 0.052 & 0.935 & 0.236 & 0.272 & 0.022 & 0.291 & 0.489 \\
\hline NAW & 0.354 & 0.045 & -0.357 & 0.899 & -0.214 & 0.330 & 0.475 & 0.362 & -0.029 \\
\hline IOC & 0.082 & 0.972 & -0.034 & 0.317 & -0.128 & 0.085 & 0.598 & 0.148 & 0.116 \\
\hline ZYW & 0.372 & -0.101 & -0.222 & 0.821 & 0.067 & 0.390 & -0.056 & 0.439 & -0.021 \\
\hline PL & 0.374 & -0.091 & -0.249 & 0.827 & 0.026 & 0.385 & 0.223 & 0.305 & -0.508 \\
\hline BL & 0.320 & -0.129 & 0.466 & 0.629 & 0.507 & 0.282 & -0.391 & 0.217 & 0.014 \\
\hline
\end{tabular}

continued.

Forms with 5 laminae in $\mathrm{m} 1$ (Fig. 10)

O. typus s.l. (Fig. 12)

\begin{tabular}{lllllll}
\hline & PC1 & PC2 & CV1 & CV2 & CV1 & CV2 \\
GLS & 0.411 & 0.017 & 0.565 & 0.422 & 0.250 & 0.741 \\
BCD & 0.264 & -0.112 & 0.352 & 0.150 & 0.233 & 0.766 \\
APF & 0.367 & 0.147 & 0.317 & 0.509 & 0.251 & 0.557 \\
MXTRL & 0.235 & -0.529 & 0.827 & -0.357 & 0.049 & 0.360 \\
NAW & 0.272 & 0.288 & 0.073 & 0.033 & 0.164 & 0.678 \\
IOC & 0.143 & 0.745 & -0.217 & 0.659 & -0.191 & 0.411 \\
ZYW & 0.372 & 0.041 & 0.569 & 0.588 & 0.249 & 0.451 \\
PL & 0.342 & -0.095 & 0.541 & 0.178 & -0.105 & 0.768 \\
BL & 0.312 & -0.186 & 0.664 & 0.275 & 0.677 & 0.541 \\
\hline
\end{tabular}

Morphometric separation of the six hypothesized taxa was further emphasized by canonical variates analysis (CVA) as shown in Fig. 6. CVA resulted in $100 \%$ correct classification of four of the six hypothesized species: fortior (OTU 2), O. yaldeni sp. nov. (= "Sp. A") (OTU 5), O. cheesmani sp. nov. (= "Sp. C”; see Taxonomic Summary) (OTU 4) and O. simiensis sp. nov. (= "Sp. D”) (OTU 6). In O. typus s.s. three of four specimens (75\%) were correctly identified, as were 18 of 19 specimens (95\%) of $O$. helleri (= "Sp. B") (OTU 3).

Specimens from unassigned ("unknown") localities (OTU 7) were plotted on the canonical variates plot shown in Fig. 6 and their affiliations predicted a posteriorly from the CVA. Thus, for example, specimens from Jimma, although very close geographically to the type locality of fortior (Charada Forest; Fig. 1), grouped with $O$. cheesmani sp. nov. (= "Sp. C"); statistically, three of the four specimens were classified as O. cheesmani $\mathbf{s p . ~ n o v . ~ ( = ~ " S p . ~}$ C") while the fourth was classified as $O$. typus s.s. The same process was repeated with all the specimens listed in OTU 7 (Table 2; results not shown). At three localities all or most of the specimens were assigned by CVA to "Sp. B": Ankober $(n=1 ; 100 \%)$, Bongke $(n=2 ; 100 \%)$, and Chilalo $n=6 ; 83 \%)$. The last-mentioned locality is the type locality of helleri; thus the name helleri can be equated with the taxon "Sp. B" of Lavrenchenko et al. (1997). The assignment of specimens from other unassigned localities was more ambiguous; thus Hirna comprises specimens assigned to both typus s.s. $(\mathrm{n}=1)$ and "Sp. B" $(\mathrm{n}=1)$ whilst Chenca includes specimens assigned to typus s.s. $(\mathrm{n}=2)$, fortior (n=2), O. helleri (= "Sp. B") $(\mathrm{n}=4)$ and $O$. yaldeni sp. nov. (= "Sp A") $(\mathrm{n}=1)$.

Relative warps analysis (RWA) of dorsal landmarks on a subset of crania (Fig. 7) indicated shape differences between topotypic specimens of typus s.s. from Simien Mts, specimens of O. helleri ("Sp. B") from the Bale Massif and neighbouring Arussi Plateau and the type specimen of fortior from Charada Forest.

East African Highlands sample. In spite of minor overlap, specimens of tropicalis from East Africa show a trend of increasing cranial size from Mt Elgon (smallest; low scores on PC1) to the Aberdare Mts (intermediate) to 
Mt Kenya (largest; high scores on PC1) (Fig. 8a; Table 6). Specimens classified as orestes from the Aberdares and Mt Kenya overlap in size with tropicalis but are almost completely distinguished from tropicalis on skull shape (PC2) by having narrower interorbit and nasals, a deeper cranium and larger bullae (Fig. 8a; Table 6).

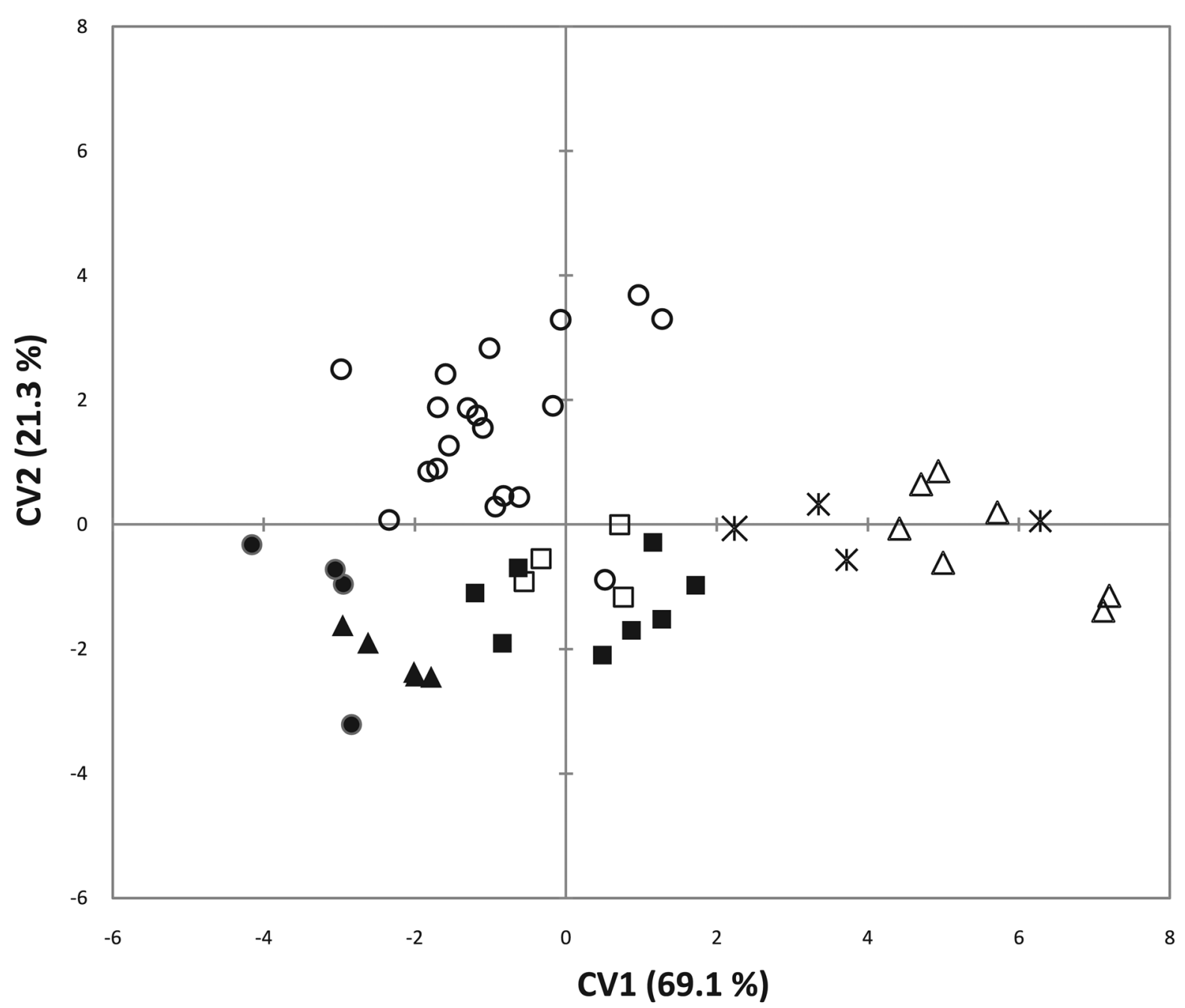

FIGURE 6. Canonical variates analysis (plot of first two canonical variates) of six defined taxon-groups of Ethiopian Otomys based on nine craniometric variables. Position of individuals form "unknown" sample from Oromiya, Jimma (asterisks) predicted a posteriori. Open squares $=$ O. typus s.s. $($ Mt Guna); Closed squares $=O$. fortior ; open circles $=O$. helleri $(=$ "Sp. B"); closed circles = O. yaldeni sp. nov. (= "Sp. A"); open triangles = O. cheesmani sp. nov. (= "Sp. C"); closed triangles $=O$. simiensis sp. nov. (= "Sp. D”).

Specimens from the summit of the Aberdares having five laminae in m1 (OTU 11 indicated as open circles in Fig. 8a) overlap in cranial size and shape with $O$. tropicalis from Aberdares (closed circles) and Mt Kenya (open diamonds). One $O$. tropicalis specimen from the Aberdares (RMCA a1.008-M-1122; Field No. R28198) which formed a distinct clade from topotypic $O$. tropicalis based on its cyt $b$ sequences (grouping closest to a specimen of O. tropicalis elgonis from Mt Elgon), was distinctly smaller than all other Aberdares specimens and grouped with smaller-sized specimens from Mt Elgon. Another Aberdares specimen initially classified as $O$. tropicalis (RMCA a1.008-M-1123; Field No. R28205) which grouped genetically with O. orestes (Fig. 3) clustered morphometrically with $O$. orestes, confirming its identification.

The holotypes of $O$. percivali, malleus and squalus from the Aberdares Range all fall within the cluster represented by $O$. orestes (Figs. 8a and $8 \mathrm{~b}$ ), whereas a series of four specimens from the type locality of $O$. thomasi (Molo on the Mau Escarpment), and one individual from the Guas Ngishu Plateau (USNM 164290) fall mostly (with one exception) outside the size range (PC1 scores) of O. orestes (due to their larger size: PC1 scores -3.6 to 1.1 in $O$. orestes compared to 0.2 to 3.1 in thomasi) but within the shape range of $O$. orestes (PC2 scores) (Fig. 8b; Table 6). 


\section{O. fortior holotype \\ (Charada Forest)}
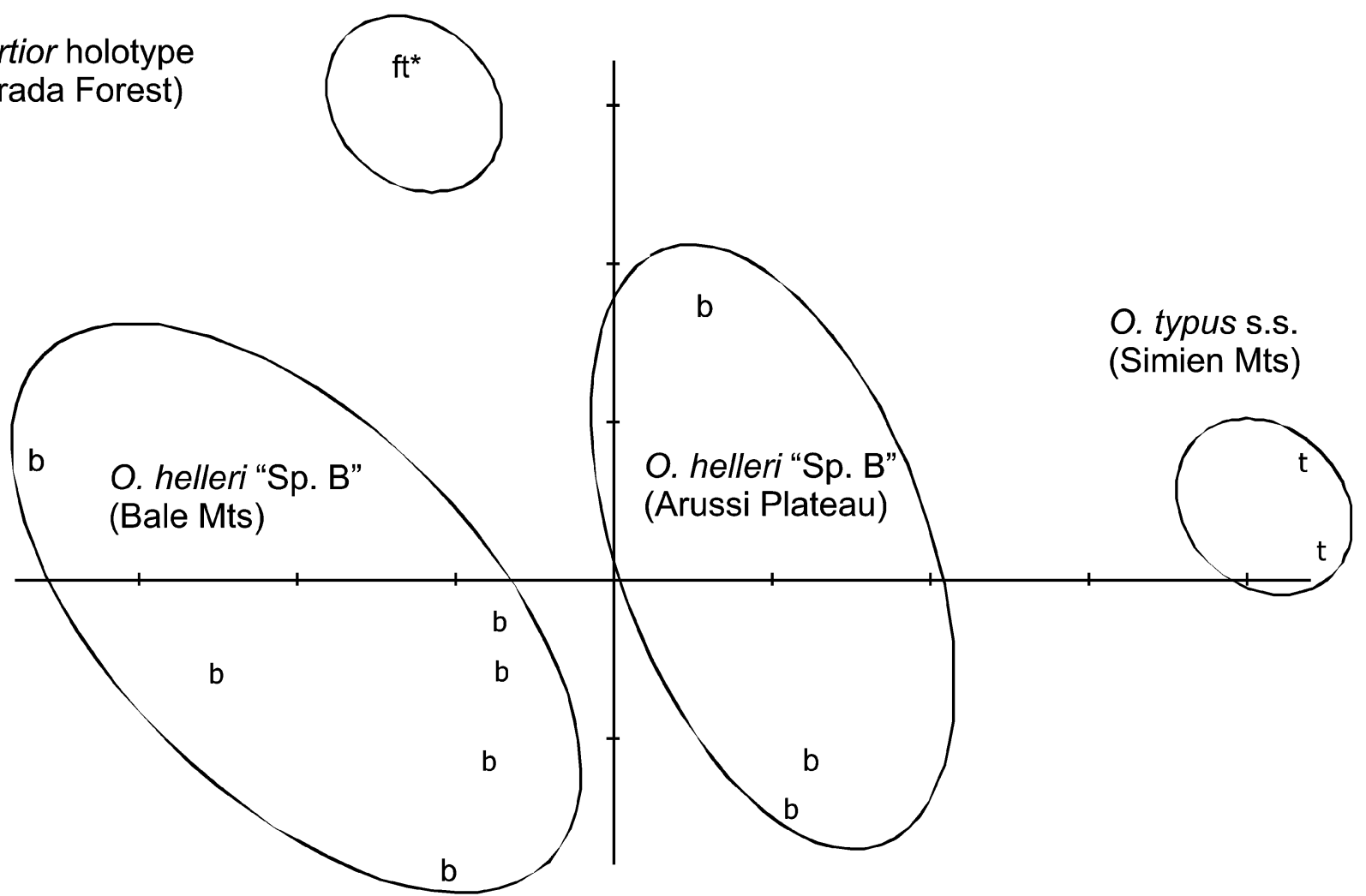

FIGURE 7. Relative warps analysis (RW) of 14 dorsal landmarks from 12 Ethiopian individuals assigned to $O$. typus s.s. from Simien Mts ("t"), O. helleri (= Sp. B: "b"; Dinsho and Arussi Plateau) and O. fortior ("ft"*; type specimen from Charada Forest).

The deeper, more arched cranial profile of $O$. orestes and $O$. thomasi relative to $O$. tropicalis is clearly reflected in the thin plate splines associated with Relative Warp 1 in RWA of lateral landmarks (Fig. 9). This analysis also confirms the overlap in cranial shape between $O$. tropicalis specimens from the Aberdares having either 4 or $5 \mathrm{~m} 1$ laminae.

The Aberdares summit sample having $5 \mathrm{~m} 1$ laminae is distinguished on linear variables from other East Africa taxa having five laminae in $\mathrm{m} 1$ (Fig. 10), by having a narrower interorbit than $O$. lacustris (low scores on PC2: see Table 6 for eigenvector loadings), and being larger in size than O. barbouri (high scores on PC1). CVA confirms the complete separation between the three taxa. Completely separable from $O$. lacustris on dorsal shape, based on its broader and shorter cranial form and more abrupt angle of anterior expansion of the nasal (RW1), the Aberdares summit tropicalis population is partly distinguished from $O$. barbouri on RW2, based on wider separation of the three landmarks defining the internal and external angles of the posterior roots of the zygomatic arch and the dorsal extension of the mastoid (Fig. 11)

\section{Regional relationships}

Univariate results. Table 7 documents ANOVA results and multiple range tests for the typus s.l. group. This complex is characterized by significant inter-OTU differences in all variables; these differences tend to explain high proportions of the total variance (44-75\%). Within the typus group, jacksoni is smallest in most variables whilst "Sp. C" is largest in all but one variable (interorbital constriction); in three variables (GLS, MXTRL and NAW), "Sp. C" occupies a unique significant subset indicating distinctive morphometric separation from all other species. Apart from Ethiopian "Sp. C", O. thomasi usually displays the highest mean values. Exceptions include maxillary toothrow length (MTR) where typus s.s., fortior and "Sp. B" display the greatest mean values (due to their higher modal number of eight laminae in M3; Table 4), and greatest braincase depth (BCD) and maximum zygomatic arch (ZYW) where thomasi and orestes display the greatest mean values (due to their arched lateral profile and "boxy" 

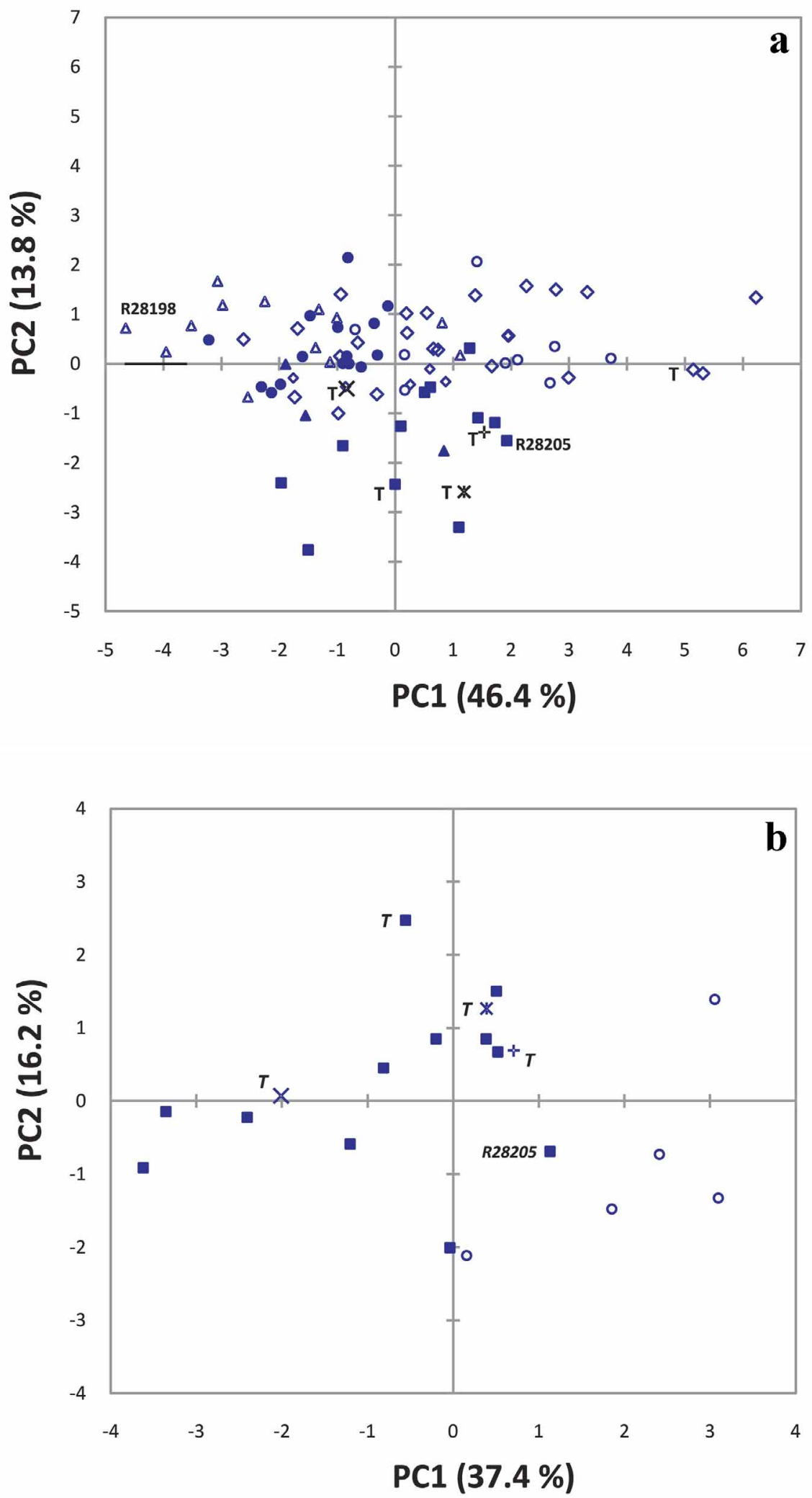

FIGURE 8. PCA of nine linear variables comparing $O$. orestes (closed squares) with: (a) East African populations of $O$. tropicalis from Aberdares (closed and open circles representing samples with 4 and 5 laminae in lower M1 respectively), Mt Elgon (open triangles) and Mt Kenya (open diamond) and (b) topotypic specimens of $O$. thomasi (open circles) from Molo in the Guas Ngishu Plateau. Position of type specimens of $O$. tropicalis (open diamond), $O$. orestes (closed square), percivali (asterisk), malleus (X) and squalus (cross) indicated by "T". RMCA specimens R28198 and R28205 representing divergent cyt $b$ lineages indicated. 


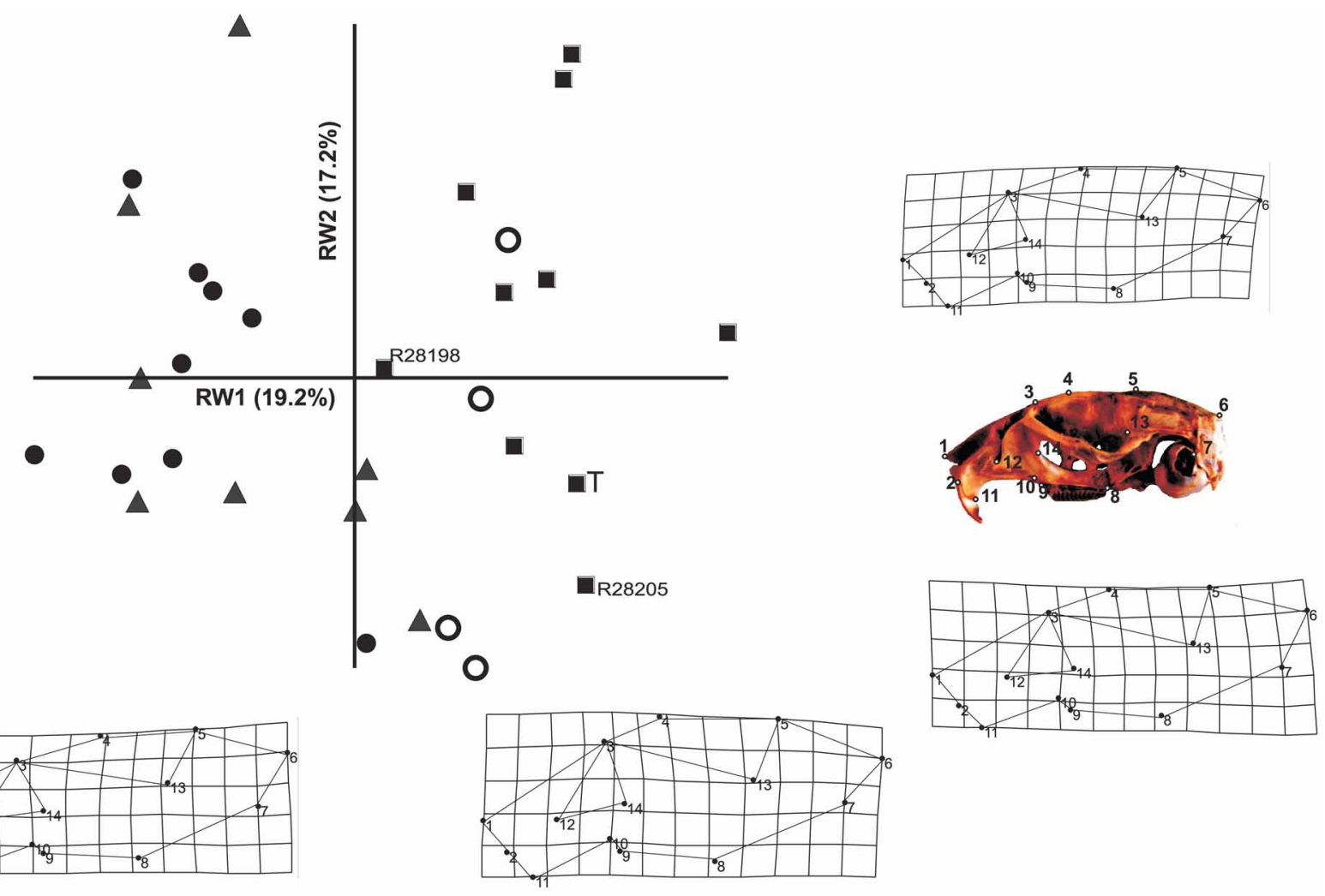

FIGURE 9. RWA of lateral landmarks showing variation in samples from the Aberdares Range of Kenya, between $O$. orestes (closed squares), $O$. tropicalis (closed triangles) and the population from the Aberdares summit having 5 laminae in $\mathrm{m} 1$ (closed circles). Topotypic specimens of thomasi from Molo in the Guas Ngishu Plateau indicated by open circles; RMCA specimens R28198 and R28205 representing divergent cyt $b$ lineages indicated. Position of type specimen indicated by "T".

divergent zygomata). Between one and five overlapping homogeneous groups are present. Whilst most groups overlap indicating clinal variation, exceptions are GLS, MXTRL, NAW where "Sp. C" forms a non-overlapping distinct subgroup.

TABLE 7. ANOVA of selected cranial variables for 12 proposed taxa of $O$. typus s.l. Homogeneous groups represent Tukey's honestly significant subsets.

\begin{tabular}{|c|c|c|c|c|c|c|}
\hline \multicolumn{7}{|l|}{ Occipito-nasal skull length (GLS) } \\
\hline OTU & $\mathrm{N}$ & Mean & Groups & & & \\
\hline jacksoni & 3 & 35.1 & A & & & \\
\hline yaldeni sp. nov. (= "Sp. A") & 4 & 35.2 & A & & & \\
\hline simiensis sp. nov. (= “Sp. D”) & 5 & 37.0 & A & B & & \\
\hline uzungwensis & 10 & 37.3 & $\mathrm{~A}$ & B & & \\
\hline dartmouthi & 9 & 37.8 & A & B & $\mathrm{C}$ & \\
\hline helleri (= "Sp. B") & 25 & 38.2 & A & B & $\mathrm{C}$ & \\
\hline orestes & 14 & 38.4 & A & B & $\mathrm{C}$ & \\
\hline typus s.s. & 6 & 38.8 & $\mathrm{~A}$ & B & $\mathrm{C}$ & \\
\hline zinki & 12 & 39.4 & & B & $\mathrm{C}$ & \\
\hline fortior & 8 & 39.6 & & B & $\mathrm{C}$ & \\
\hline thomasi & 5 & 40.8 & & & $\mathrm{C}$ & \\
\hline cheesmani sp. nov. (= “Sp. C”) & 7 & 45.1 & & & & $\mathrm{D}$ \\
\hline $\mathrm{F}=15.02(\mathrm{p}<<0.001) ;$ Explained $\mathrm{S}$ & & & & & & \\
\hline
\end{tabular}


continued.

Brain case depth (BCD)

\begin{tabular}{|c|c|c|c|c|c|}
\hline OTU & $\mathrm{N}$ & Mean & Groups & & \\
\hline simiensis sp. nov. (= “Sp. D”) & 5 & 10.1 & A & & \\
\hline yaldeni sp. nov. (= "Sp. A") & 4 & 10.6 & A & B & \\
\hline fortior & 8 & 10.8 & A & B & \\
\hline typus s.s & 6 & 10.9 & A & B & \\
\hline dartmouthi & 9 & 11.0 & A & B & \\
\hline jacksoni & 3 & 11.0 & A & B & $\mathrm{C}$ \\
\hline uzungwensis & 10 & 11.2 & & B & $\mathrm{C}$ \\
\hline helleri (= "Sp. B") & 25 & 11.2 & & B & $\mathrm{C}$ \\
\hline zinki & 12 & 11.5 & & B & $\mathrm{C}$ \\
\hline thomasi & 5 & 11.5 & & B & $\mathrm{C}$ \\
\hline orestes & 14 & 11.8 & & & $\mathrm{C}$ \\
\hline cheesmani sp. nov. (= “Sp. C”) & 7 & 11.9 & & & $\mathrm{C}$ \\
\hline $\mathrm{F}=7.01(\mathrm{p}<<0.001) ;$ Explained $\mathrm{S}$ & & & & & \\
\hline
\end{tabular}

continued.

\begin{tabular}{|c|c|c|c|c|c|c|c|c|c|}
\hline Maxillary tooth row length (MXT & & & & & & & & & \\
\hline OTU & $\mathrm{N}$ & & Mean & & Groups & & & & \\
\hline jacksoni & 3 & & 8.4 & & A & & & & \\
\hline yaldeni sp. nov. (= "Sp. A") & 4 & & 8.4 & & A & & & & \\
\hline dartmouthi & 9 & & 8.8 & & A & B & & & \\
\hline simiensis sp. nov. (= “Sp. D”) & 5 & & 8.8 & & A & B & & & \\
\hline uzungwensis & 10 & & 9.1 & & A & B & & & \\
\hline zinki & 12 & & 9.2 & & A & B & & & \\
\hline orestes & 14 & & 9.3 & & & B & $\mathrm{C}$ & & \\
\hline thomasi & 5 & & 9.4 & & & B & $\mathrm{C}$ & & \\
\hline helleri (= "Sp. B") & 25 & & 9.7 & & & & $\mathrm{C}$ & $\mathrm{D}$ & \\
\hline fortior & 8 & & 9.8 & & & & $\mathrm{C}$ & $\mathrm{D}$ & \\
\hline typus s.s. & 6 & & 10.2 & & & & & $\mathrm{D}$ & \\
\hline cheesmani sp. nov. (= “Sp. C”) & 7 & & 11.3 & & & & & & $\mathrm{E}$ \\
\hline $\mathrm{F}=26.05(\mathrm{p}<<0.001) ;$ Explained & $1.9 \%$ & & & & & & & & \\
\hline continued. & & & & & & & & & \\
\hline Nasal width (NAW) & & & & & & & & & \\
\hline OTU & & $\mathrm{N}$ & & Means & & Groups & & & \\
\hline yaldeni sp. nov. (= "Sp. A") & & 4 & & 6.1 & & A & & & \\
\hline jacksoni & & 3 & & 6.4 & & A & B & & \\
\hline helleri (= "Sp. B") & & 25 & & 6.6 & & A & B & & \\
\hline simiensis sp. nov. (= “Sp. D”) & & 5 & & 6.6 & & A & B & $\mathrm{C}$ & \\
\hline dartmouthi & & 9 & & 6.8 & & A & B & $\mathrm{C}$ & \\
\hline orestes & & 14 & & 6.9 & & A & B & $\mathrm{C}$ & \\
\hline typus s.s & & 6 & & 7.1 & & & B & $\mathrm{C}$ & \\
\hline zinki & & 12 & & 7.1 & & & B & $\mathrm{C}$ & \\
\hline thomasi & & 5 & & 7.1 & & & B & $\mathrm{C}$ & \\
\hline uzungwensis & & 10 & & 7.2 & & & B & $\mathrm{C}$ & \\
\hline fortior & & 8 & & 7.3 & & & & $\mathrm{C}$ & \\
\hline cheesmani sp. nov. (= “Sp. C”) & & 7 & & 8.6 & & & & & $\mathrm{D}$ \\
\hline $\mathrm{F}=18.77(\mathrm{p}<<0.001) ;$ Explained & $.2 \%$ & & & & & & & & \\
\hline
\end{tabular}


continued.

Inter-orbital constriction (IOC)

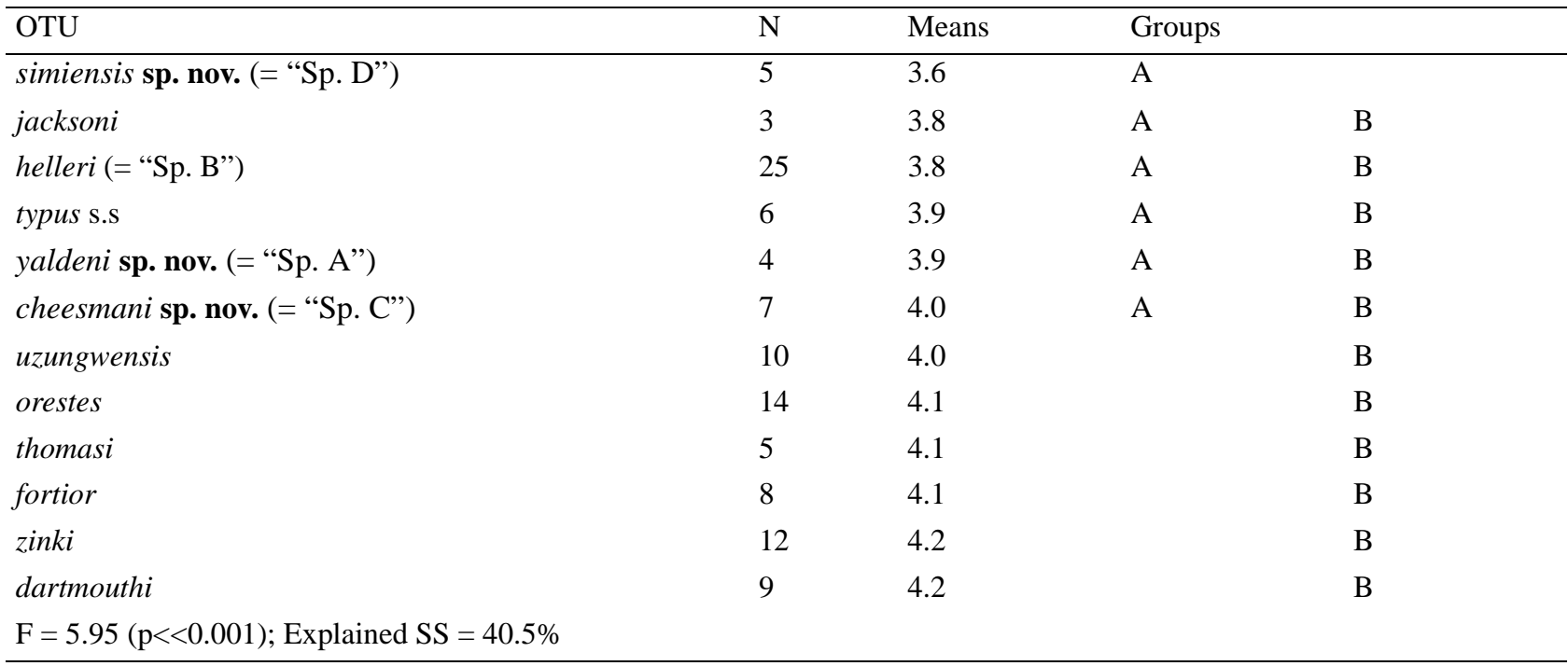

continued.

\begin{tabular}{|c|c|c|c|c|c|c|c|c|}
\hline \multicolumn{9}{|l|}{ Greatest zygomatic width (ZYW) } \\
\hline OTU & $\mathrm{N}$ & Means & Groups & & & & & \\
\hline jacksoni & 3 & 17.5 & A & & & & & \\
\hline yaldeni sp. nov. (= "Sp. A") & 4 & 17.6 & A & & & & & \\
\hline uzungwensis & 10 & 18.2 & A & $\mathrm{B}$ & & & & \\
\hline simiensis sp. nov. (= “Sp. D”) & 5 & 18.4 & A & $\mathrm{B}$ & $\mathrm{C}$ & & & \\
\hline helleri (= "Sp. B”) & 25 & 19.0 & A & $\mathrm{B}$ & $\mathrm{C}$ & & & \\
\hline typus s.s. & 6 & 19.2 & A & $\mathrm{B}$ & $\mathrm{C}$ & & & \\
\hline dartmouthi & 9 & 19.2 & A & $\mathrm{B}$ & $\mathrm{C}$ & & & \\
\hline zinki & 12 & 19.2 & A & $\mathrm{B}$ & $\mathrm{C}$ & & & \\
\hline fortior & 8 & 19.4 & & $\mathrm{~B}$ & $\mathrm{C}$ & $\mathrm{D}$ & & \\
\hline orestes & 14 & 19.5 & & & $\mathrm{C}$ & $\mathrm{D}$ & & \\
\hline thomasi & 5 & 20.8 & & & & $\mathrm{D}$ & & $\mathrm{E}$ \\
\hline cheesmani sp. nov. (= “Sp. C”) & 7 & 21.5 & & & & & & $\mathrm{E}$ \\
\hline \multicolumn{9}{|c|}{$\mathrm{F}=11.8(\mathrm{p}<<0.001) ;$ Explained SS $=57.5 \%$} \\
\hline \multicolumn{9}{|c|}{ continued. } \\
\hline \multicolumn{9}{|l|}{ Maximum bulla length (BUL) } \\
\hline OTU & & $\mathrm{N}$ & Means & Groups & & & & \\
\hline yaldeni sp. nov. (= "Sp. A") & & 4 & 6.6 & $\mathrm{~A}$ & & & & \\
\hline jacksoni & & 3 & 7.0 & A & B & & & \\
\hline simiensis sp. nov. (= “Sp. D”) & & 5 & 7.0 & A & B & & & \\
\hline dartmouthi & & 9 & 7.0 & A & B & & & \\
\hline uzungwensis & & 10 & 7.2 & A & B & & & \\
\hline typus s.s. & & 6 & 7.7 & & B & & $\mathrm{C}$ & \\
\hline fortior & & 8 & 7.8 & & B & & $\mathrm{C}$ & \\
\hline helleri (= “Sp. B”) & & 25 & 7.8 & & & & $\mathrm{C}$ & \\
\hline orestes & & 14 & 7.9 & & & & $\mathrm{C}$ & \\
\hline zinki & & 12 & 8.0 & & & & $\mathrm{C}$ & \\
\hline thomasi & & 5 & 8.3 & & & & $\mathrm{C}$ & \\
\hline cheesmani sp. nov. (= “Sp. C”) & & 7 & 8.3 & & & & $\mathrm{C}$ & \\
\hline $\mathrm{F}=11.92(\mathrm{p}<<0.001) ;$ Explained & $8 \%$ & & & & & & & \\
\hline
\end{tabular}




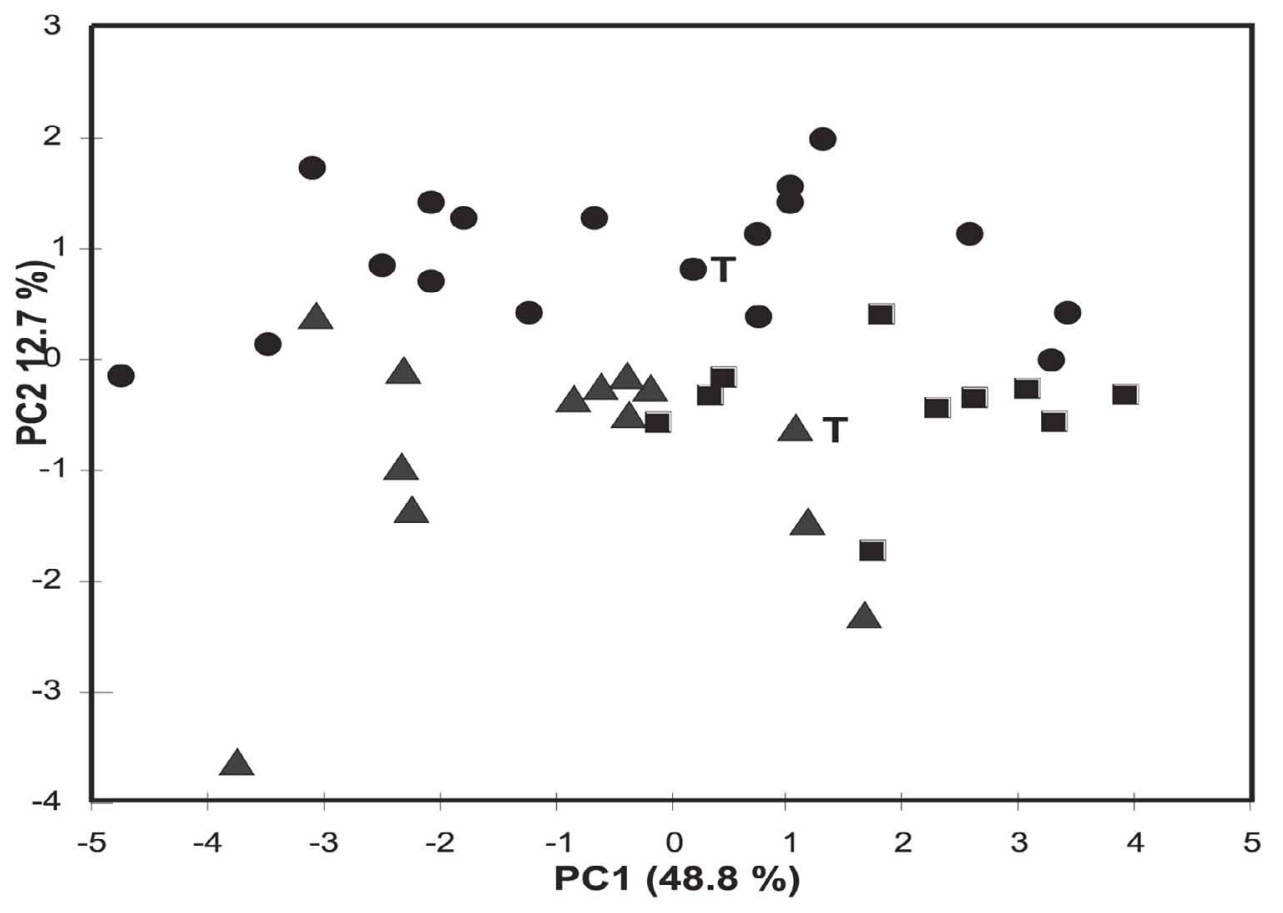

a)

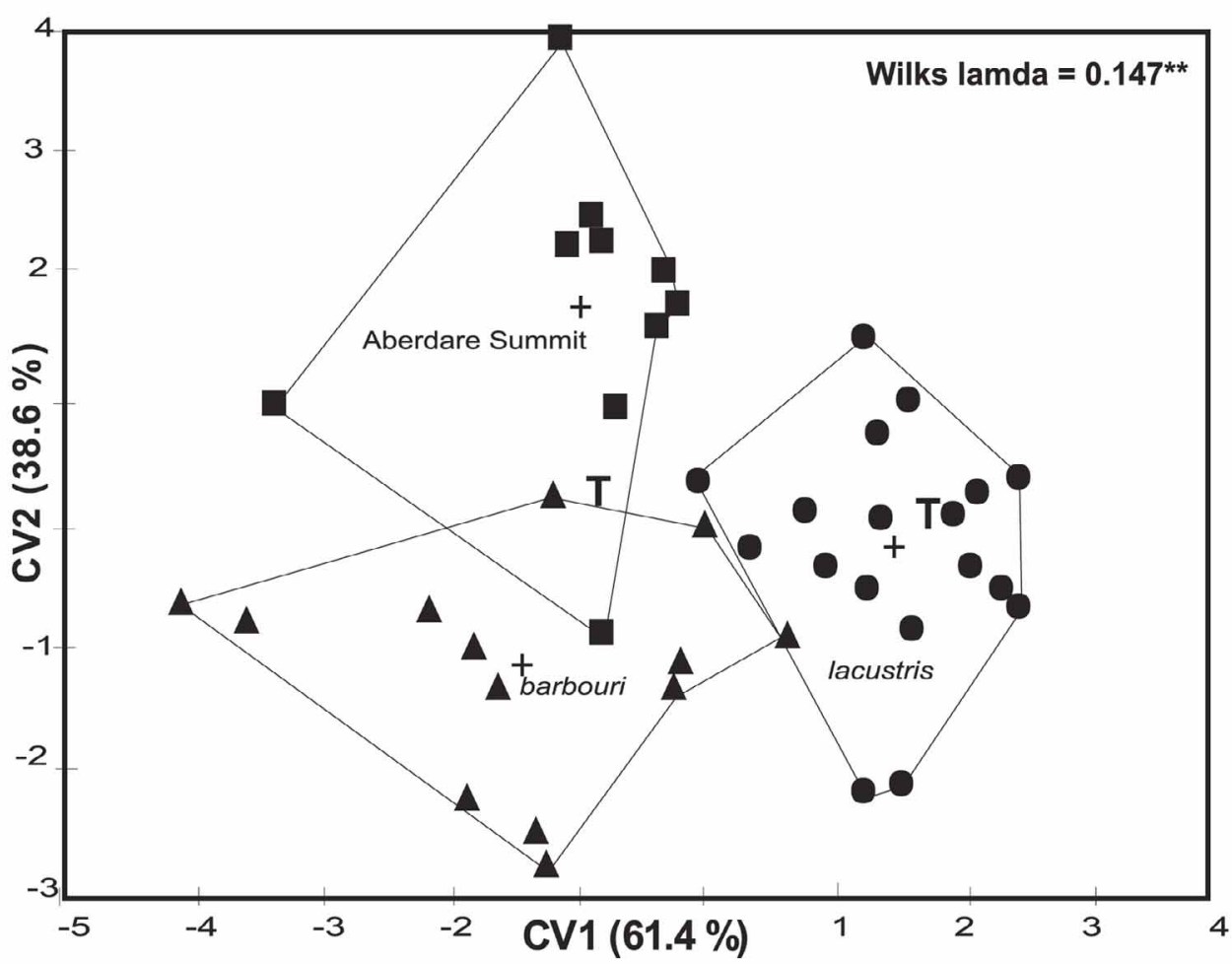

b)

FIGURE 10. PCA (a) and CVA (b) of linear variables showing craniometric separation between the population from Aberdares summit (closed squares) and other eastern African species sharing five laminae in $\mathrm{m} 1$ (O. barbouri, closed triangles, and $O$. lacustris, closed circles). Positition of type specimens indicated by " $T$ ". 


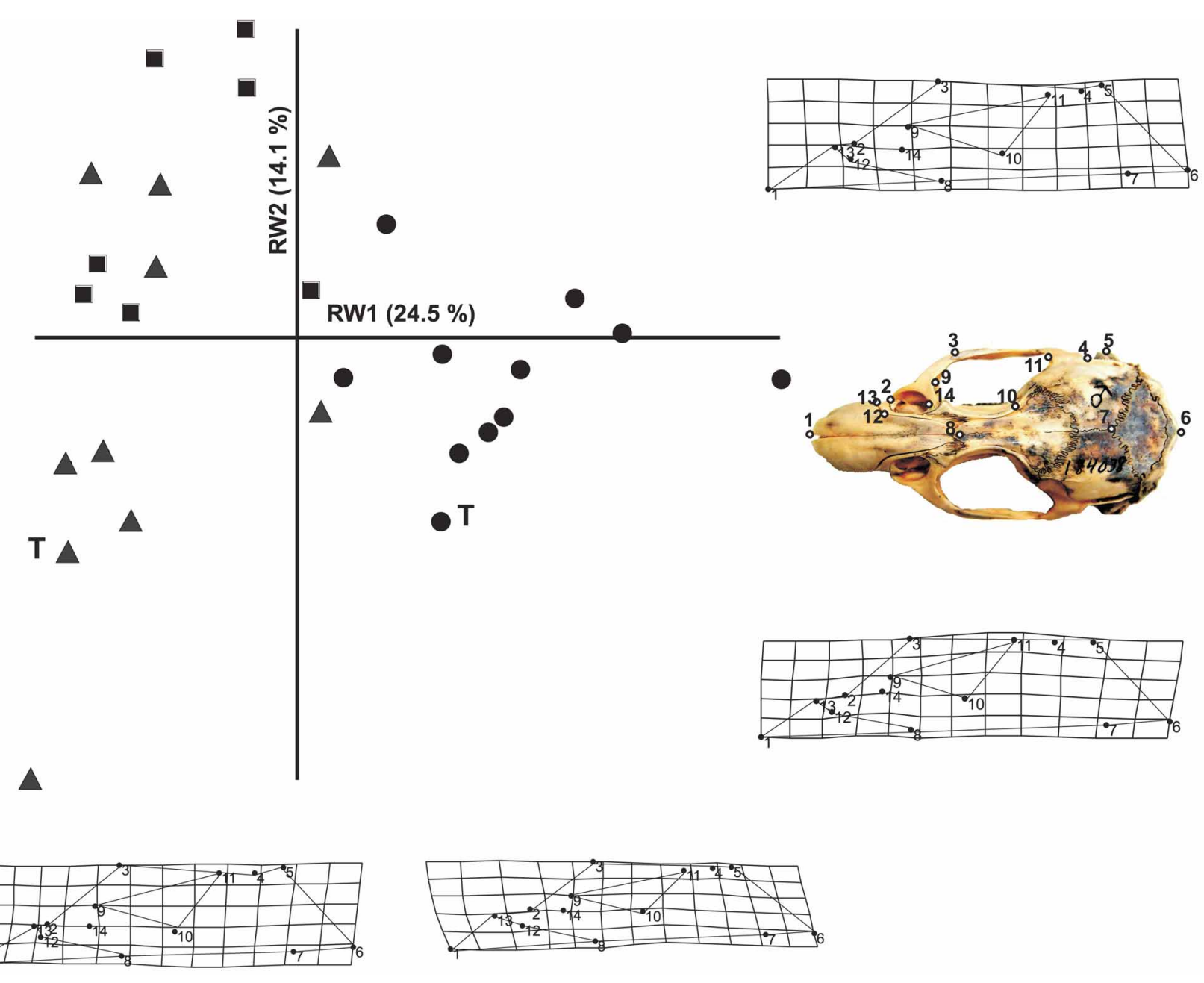

FIGURE 11. RWA of dorsal landmarks showing craniometric separation between east African species sharing five laminae in $\mathrm{m} 1$ (O. barbouri, closed triangles, O. lacustris, closed circles, Aberdares Summit population, closed squares). Position of type specimens indicated by "T".

Multivariate results. Broader morphometric relationships amongst alpine zone Otomys forms in Ethiopia, East and Central Africa are shown in Figs. 12-14. The most distinct form is "Sp. C" from the Lake Tana region of western Ethiopia (highest CV1 scores; Fig. 12, Table 6, and forming a highly divergent branch on the phenogram of Mahalanobis distances between group means). Apart from "Sp. C", Ethiopian and east African alpine forms overlap widely in cranial linear dimensions. As summarized by Mahalanobis phenogram (Fig. 12b), notwithstanding "Sp. C" there are two morphometric groups representing larger-sized (typus s.s., fortior, "Sp. B", orestes, thomasi, zinki) and smaller-sized taxa (“Sp. A", "Sp. D”, dartmouthi, jacksoni, uzungwensis).

Alpine forms were even less well resolved by landmark data (Figs. 13, 14) compared with the linear data. However, on dorsal landmarks, specimens of $O$. orestes and from the alpine Mt Kilimanjaro population (zinki) are mostly separated from other forms in having a marked forward shear (more acutely angled) of the shorter anterior zygomatic arch (Fig. 13). In lateral profile, individuals of $O$. orestes and $O$. thomasi separate partially from other alpine forms on RW2, having a more pronounced lateral arching, in particular a deeper cranium at the level of the orbit (the "ram's head" described by Dollman 1915 as being most pronounced in thomasi) and a longer, more downward-angled parietal outline (between landmarks 4 and 5) (Fig. 14). RW2 also tends to separate uzungwensis (more pronounced arching) from dartmouthi (less pronounced). 


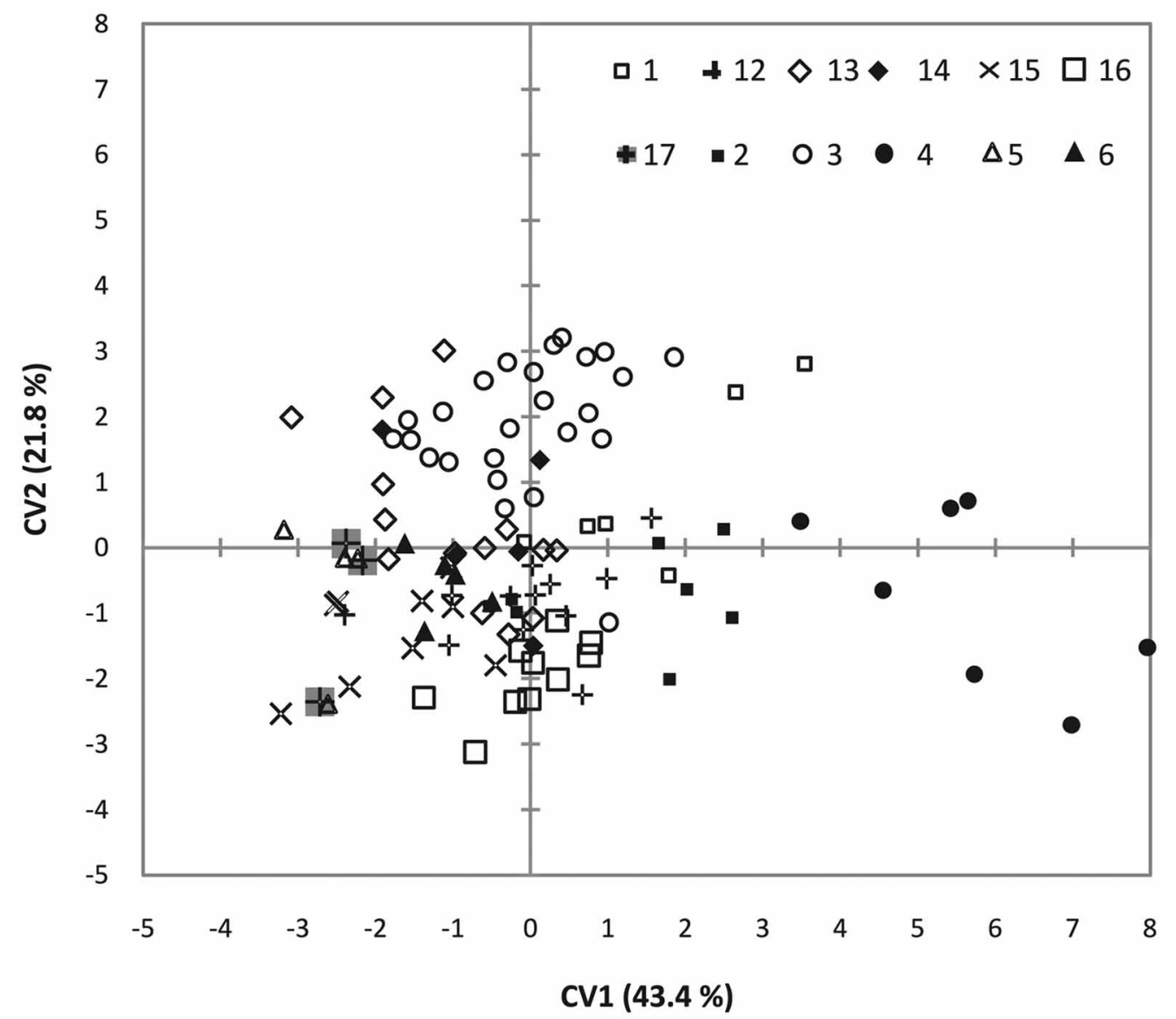

a

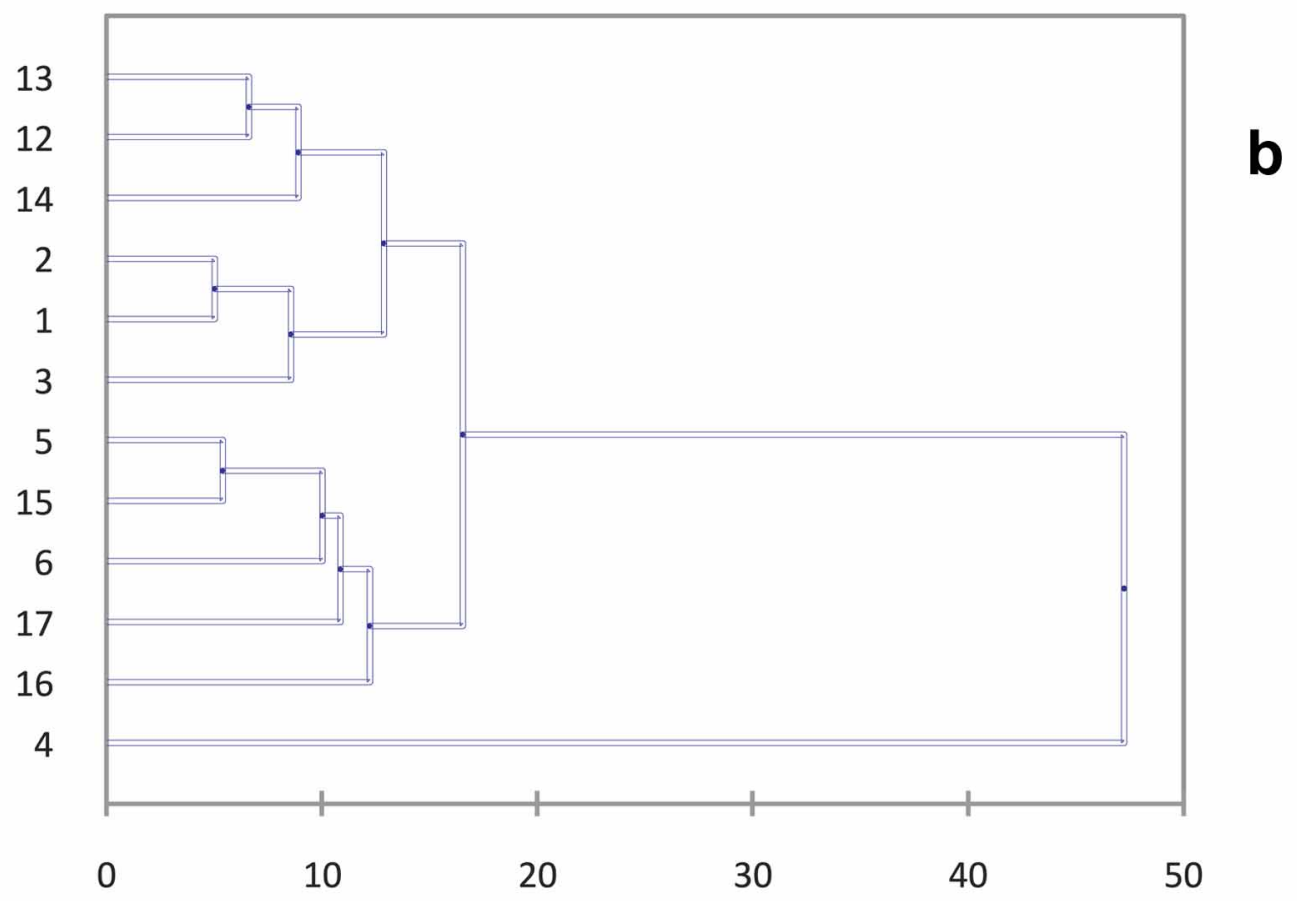

Mahalanobis Distances

FIGURE 12. CVA (a) of linear variables showing craniometric separation between regional groups of specimens assigned to typus s.l. and phenogram (b) based on Mahalanobis distances between OTUs. Numbers represent OTU numbers in Table 2. 


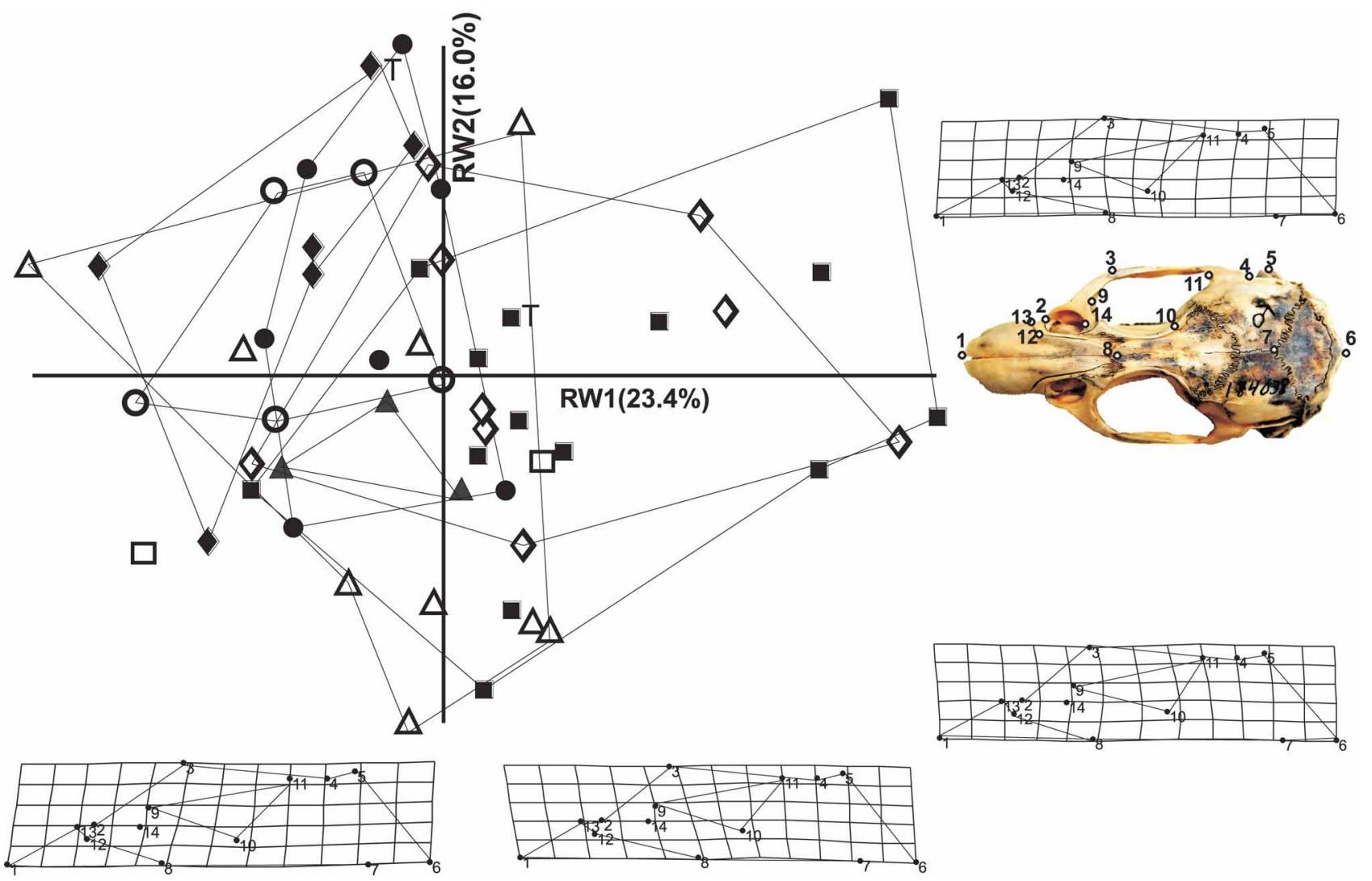

FIGURE 13. Relative warps analysis of dorsal landmarks showing craniometric separation between regional groups of specimens from alpine habitats assigned to typus s.l. Closed squares = orestes; closed circles = Aberdare summit; closed triangles = dartmouthi , closed diamonds = typus s.1. $($ Ethiopia $)$; open squares $=j a c k s o n i ;$ open circles $=$ thomasi , open triangles $=u z u n g w-$ ensis; open diamonds $=$ zinki .

\section{Ecological data}

PCA of bioclimatic variables. Based on PCA of nine bioclimatic variables, Fig. 15 summarises ecological relationships between localities representing O. typus s.1. (47 localities: Fig. 15; Table 8). Populations of most alpine forms of $O$. typus s.l. are notably segregated ecologically. This is particularly marked in the case of the Ethiopian forms; thus typus s.s. (Simien Mts), O. cheesmani sp. nov. (= "Sp. C”) (Lake Tana Region), and O. yaldeni sp. nov. (= "Sp. A") (lower altitudes within the Bale Mts) occupy unique bioclimatic niches quite distinct from each other and from O. helleri (= "Sp. B") (higher altitudes within the Bale Mts, Arussi Plateau), thomasi (from Uasin Gishu Plateau in Kenya) and fortior (sub-alpine forests of southwestern Ethiopia). However, helleri (= "Sp. B"), thomasi and fortior overlap ecologically.

Forms of typus s.l. separate on PC1 on the basis of an inverse relationship between altitude/precipitation and temperature (see eigenvectors: Table 8; high positive scores indicating higher elevation, colder and wetter climates), and on PC2 on the basis of seasonality in temperature and precipitation. On PC2, populations further north or south from the equator (Simien Mts (typus s.s.), Kilimanjaro (zinki) and the Eastern Arc and Nyika Plateau (uzungwensis)) show greater seasonality compared to those from the more equatorial Kenyan Highlands, Mt Elgon and the Albertine Rift. Albertine Rift (dartmouthi) occupies the most seasonally equitable bioclimatic niche. Whilst orestes, fortior, jacksoni and "Sp. B" have intermediate values on PC2 ("seasonality"), jacksoni differs clearly from the others on PC1 (low scores indicating relatively low precipitation and high temperatures, possibly due to its proximity to the equator).

The positions of Ethiopian localities of uncertain taxonomic affiliation (lacking molecular and chromosomal data) are shown on Fig. 15. Not surprisingly, Chilalo, the type locality of helleri, which is located on the Arussi Plateau, shares a similar climatic niche to geographically close localities of Mt Albasso on the Arussi Plateau and Dinsho in the Bale Mts. Likewise, Jimma, which is situated $30 \mathrm{~km}$ from Charada Forest (type locality of fortior) in 
southwestern Ethiopia groups close ecologically to localities assigned to fortior, and the localities Gombitchu (type locality of degeni) and Ankober which are situated $120 \mathrm{~km}$ apart in the central Ethiopia highlands west of the Rift Valley group with geographically close localities assigned to O. cheesmani sp. nov. (=“Sp. C") (e.g. these two localities are situated $150-250 \mathrm{~km}$ from Debra Marcos). The remaining unassigned localities are not grouped ecologically with any particular taxon: these include Chencha and Bongke in the southern highlands, Hirna in the northern highlands east of the Rift, $250 \mathrm{~km}$ north of the Arussi Plateau, and Malka (type locality of malkensis), east of the Rift and $110 \mathrm{~km}$ south of the Arussi Plateau.

TABLE 8. Eigenvectors from PCA of altitude and bioclimatic variables from 47 localities assigned to the $O$. typus s.l. species complex.

\begin{tabular}{llll}
\hline Climate variables & PC1 & PC2 & PC3 \\
\hline Altitude (m) & 0.408 & 0.081 & -0.238 \\
Bio_1_MAT & -0.405 & -0.162 & 0.237 \\
Bio_12_AP & 0.330 & 0.230 & 0.484 \\
Bio_13_MaxP_Wettest_Mth & 0.024 & 0.583 & 0.436 \\
Bio_14_MinP_Driest_Mth & 0.332 & -0.179 & 0.492 \\
Bio_15_P_Season & -0.284 & 0.468 & -0.213 \\
Bio_4_T_Season & -0.262 & 0.511 & -0.043 \\
Bio_5_MaxT_Warmest_Mth & -0.404 & -0.183 & 0.183 \\
Bio_6_MinT_Coldest_Mth & -0.370 & -0.173 & 0.374 \\
\hline
\end{tabular}
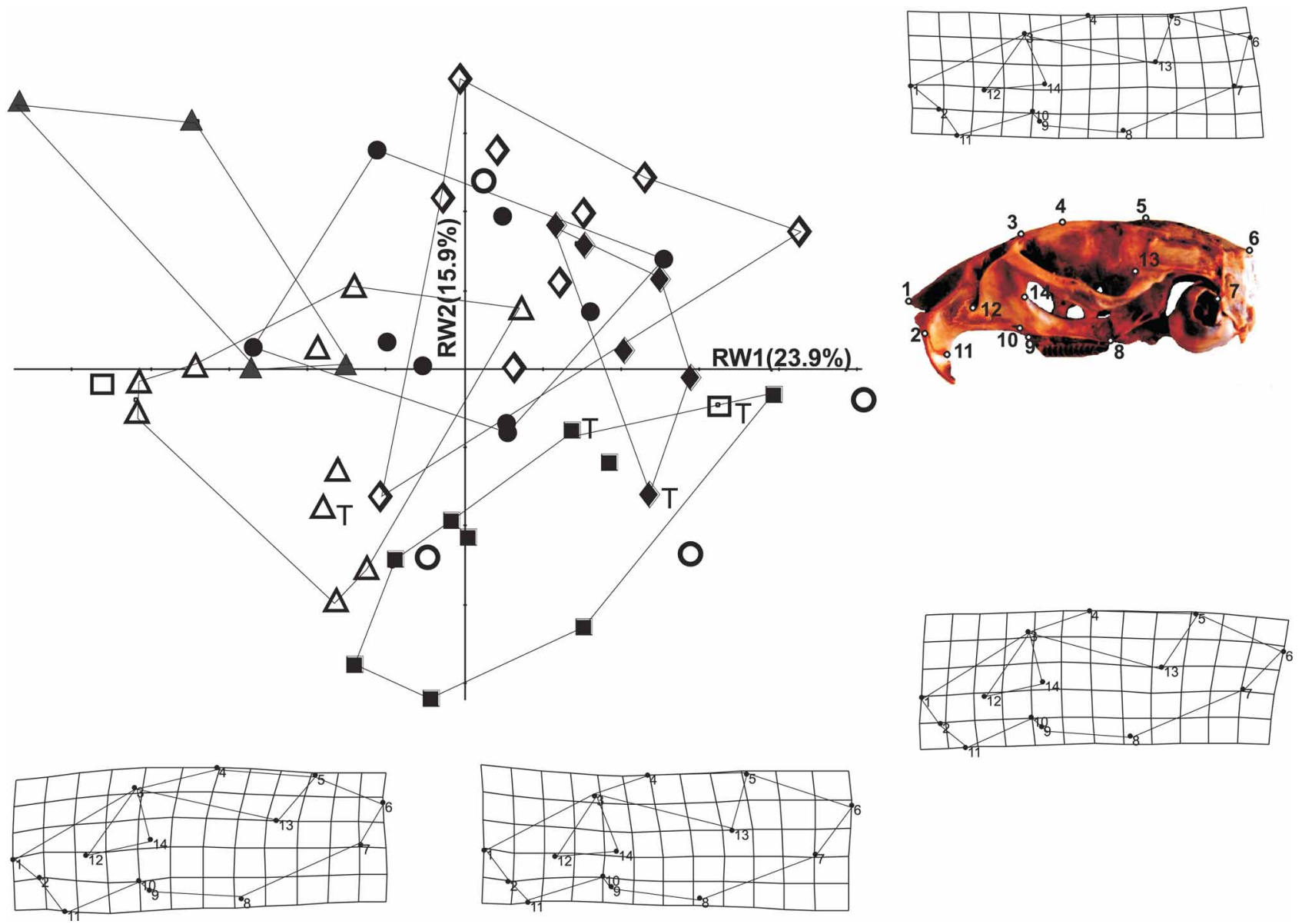

FIGURE 14. Relative warps analysis of lateral landmarks showing craniometric separation between regional groups of specimens from alpine habitats assigned to typus s.l. Closed squares = orestes; closed circles = Aberdare summit; closed triangles = dartmouthi, closed diamonds = typus s.1. $($ Ethiopia $)$; open squares $=j a c k s o n i ;$ open circles $=$ thomas $;$, open triangles $=u z u n g w-$ ensis; open diamonds $=$ zinki . 


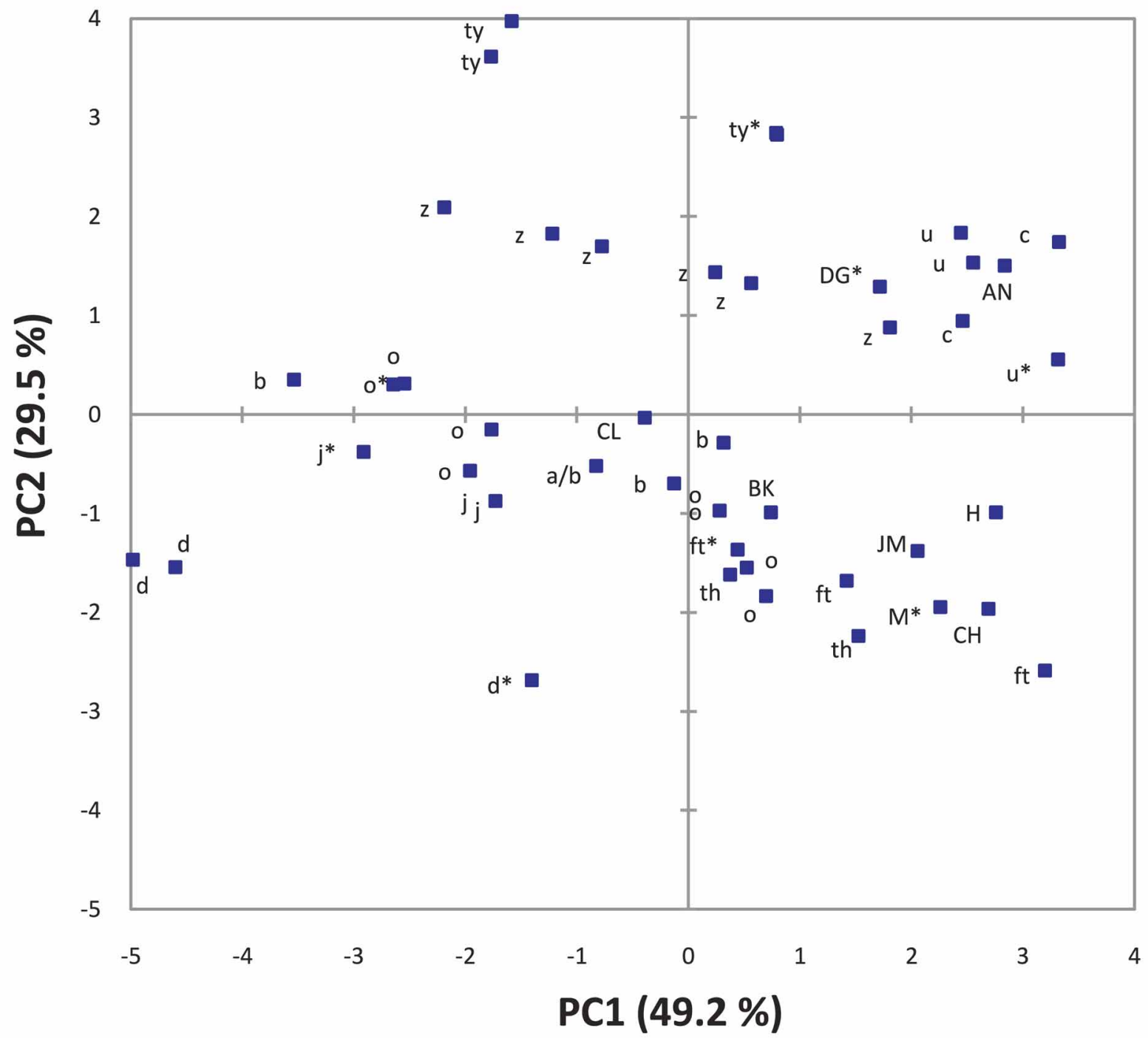

FIGURE 15. PCA summarizing variation in altitude and eight bioclimatic variables in localities of O. typus s.l. (48 localities). Asterisks denote type localities. Symbols of localities assigned to revised taxa given in lower case as follows: "ty" = typus s.s. (Ethiopia: Simien Mts, Mt Guna); "a" = yaldeni: Sp. A (Ethiopia: Bale Mts); "ft" = fortior (Ethiopia: Charada (type locality), Beletta and Sheka Forests); "b" = helleri: Sp B (Ethiopia: Bale Mts, Arussi Plateau); "c" = cheesmani: Sp. C (Ethiopia: Dangila - Debra Marcos); "d" = dartmouthi (Ruwenzori Range); "j" = jacksoni (Mt Elgon); "o" = orestes (Kenya: Aberdares and Mt Kenya); "th" = thomasi (Kenya: Uasin Gisho Plateau); "u" = uzungwensis (Malawi: Nyika Plateau and Tanzania: Southern Rift and Eastern Arc); "z" = zinki (Mt Kilimanjaro). Symbols of localities from Ethiopia, which could not be unambiguously assigned to revised taxa are labelled in upper case as follows: $\mathrm{AN}=$ Ankober; $\mathrm{BK}=$ Bongke; $\mathrm{CH}=\mathrm{Chenca}$; $\mathrm{CL}=\mathrm{Chilalo}$ (type locality of helleri); $\mathrm{H}=$ Hirna; $\mathrm{M}=$ Malka (type locality of malkensis); JM = Oromiya, Jimma.

\section{Discussion}

Intraspecific variation. Based on data from two African rodent genera, Abdel-Rahman et al. (2009) showed that ontogenetic and secondary sexual variation, although often overlooked in systematic studies, can confound taxonomic decisions based on morphometric results. Previous intra-population analyses of southern African populations of Otomys (Taylor et al. 1993, 2005; Taylor \& Kumirai 2001) demonstrated lack of significant sexual dimorphism and homogeneity of toothwear classes 4 and 5. Our results (Fig. 4; Table 5) confirm absence of significant sexual dimorphism and presence of significant ontogenetic variation in an East African population of $O$. tropicalis, where age classes 2, 3 and 4 differ significantly from each other both in size (linear variables) and shape (dorsal landmarks). Individuals of Class 2 and most Class 3 individuals display a "juvenile" skull shape with pro- 
portionately wide braincase and short facial region (Fig. 2). For this reason, with a few exceptions (e.g. type specimens), further analyses were based on pooled sexes for age class 4 and 5 individuals only.

Taxonomic conclusions. A multi-disciplinary approach emphasizes integration of biogeographic, morphometric, genetic, and ecological evidence and positions us to delimit species under the Cohesion Species Concept (Templeton 1998), which holds that species are "evolutionary lineages, with the lineage boundaries that define species arising from the forces that create reproductive communities (i.e. cohesion mechanisms)". These cohesion mechanisms are genetic exchangeability (absence of barriers to gene flow) and ecological interchangeability (occupancy of the same niche). Whilst phylogeographic data can elucidate barriers to gene flow or genetic non-exchangeability (Avise 2009), ecological non-interchangeability (occupancy of different niches) can be elucidated by adaptive morphological divergence or, in the case of cryptic species, ecological niche models (see Bond \& Stockman 2008; Stockman \& Bond 2007). In this study, we regard "good" species as those showing both genetic non-exchangeability (inferred from molecular and/or morphometric data) and ecological non-interchangeability (based on ordination of bioclimatic variables and/or adaptive morphometric trends). A weakness of this holistic approach to species definitions, particularly as it bears on practical issues of Otomys taxonomy, is that we lack full complementarity of morphometric, genetic, and ecological information across all analytical samples.

Principal components analysis of altitude and eight bioclimatic variables disclosed that eastern African alpine taxa formerly classified as subspecies of $O$. typus are mostly ecologically distinct in their ranges compared with $O$. typus s.s. from the Simien Mts of Ethiopia (Fig. 15), as well as from each other, and occupy distinct niches that are also geographically widely separated. In particular, O. dartmouthi (Ruwenzori Mts), O. jacksoni (Mt Elgon), O. uzungwensis (Udzungwa Mts), and O. zinki (Mt Kilimanjaro) showed no overlap in their bioclimatic niches. The wide geographic lowlands that isolate these "sky islands" of Afro-alpine habitat, coupled with evidence for adaptive morphometric and/or genetic ( $\mathrm{p}=8-9 \%$ ) divergence between them (see Results), substantiate their specific status. Genetic data are so far unavailable for $O$. uzungwensis, but this species can be clearly demarcated on morphometric as well as ecological grounds, as discussed above and as also demonstrated by Carleton \& Byrne (2006).

The status of $O$. thomasi and zinki in relation to O. orestes requires further comment. Carleton \& Byrne (2006) tentatively placed both in synonymy with $O$. orestes. In the case of zinki, those authors lacked topotypic examples of zinki and based their synonymy on literature descriptions and geographic proximity. Our evidence decisively portrays this form as a genetically and ecologically divergent lineage that merits species status. Although overlapping with $O$. orestes in some morphological aspects, $O$. zinki clearly lacks the arched lateral skull profile that typifies $O$. orestes.

The case for species recognition of thomasi is more tenuous. Sample size is small, genetic data are lacking, and the range of this form on the Mau Escarpment and Uasin Gishu Plateau overlaps ecologically with the lower altitudinal reaches of the alpine form, $O$. orestes on Mt Kenya and the Aberdares. Nevertheless, whereas type specimens of malleus, percivali and squalus from the Aberdares (east of the eastern Rift Valley) clustered within the range of variation of $O$. orestes, the topotypic series of thomasi from Molo in the Mau Escarpment (western rim of the eastern Rift Valley) falls almost completely outside the range of variation of $O$. orestes, owing principally to their larger size (easily evidenced by external variables; Table 9; Fig. 16b). Furthermore, specimens of thomasi have an overall paler buffy pelage when compared to those of $O$. orestes and from our observations, lack the pale aural tufts of the latter (Fig. 16b). In view of the geographical barrier imposed by the eastern Rift Valley, separating alpine habitats on mountains to the east (Mt Kenya and Aberdares) and west (Uasin Gishu Plateau and Mau Escarpment), the observed size and colour differences between $O$. orestes and thomasi may indicate adaptive divergence and hence ecological non-interchangeability. Given the large genetic distances that distinguish other isolated East African alpine forms - e.g., on Mt Elgon (O. jacksoni), the Ruwenzoris (O. dartmouthi), and Mt Kilimanjaro (O. zinki)— we predict that high genetic divergence will be found to separate thomasi from $O$. orestes. Pending availability of such data, we consider it parsimonious to provisionally recognize $O$. thomasi as a distinct evolutionary lineage and valid species, as it was initially described by Osgood (1910).

The situation in Ethiopia is also ambiguous. A very deep genetic divergence separates the chromosomally distinct $O$. simiensis sp. nov. (= "Sp. D") from Simien Mts (with $2 \mathrm{n}=54, \mathrm{NFa}=54$ ) from populations having the common karyotype of $2 \mathrm{n}=58, \mathrm{NFa}=58$ (O. typus s.s., O. fortior, and $O$. helleri (= "Sp. B")). Although the last-mentioned three forms differ only by around 3\% (uncorrected $p$-distance), the ecological and biogeographic separation of these forms argues for species status. Populations of $O$. helleri from the Bale Mts and Arussi Plateau occur east of the Rift Valley (a major barrier to dispersal) and are morphometrically distinct from other Ethiopian populations, 
a
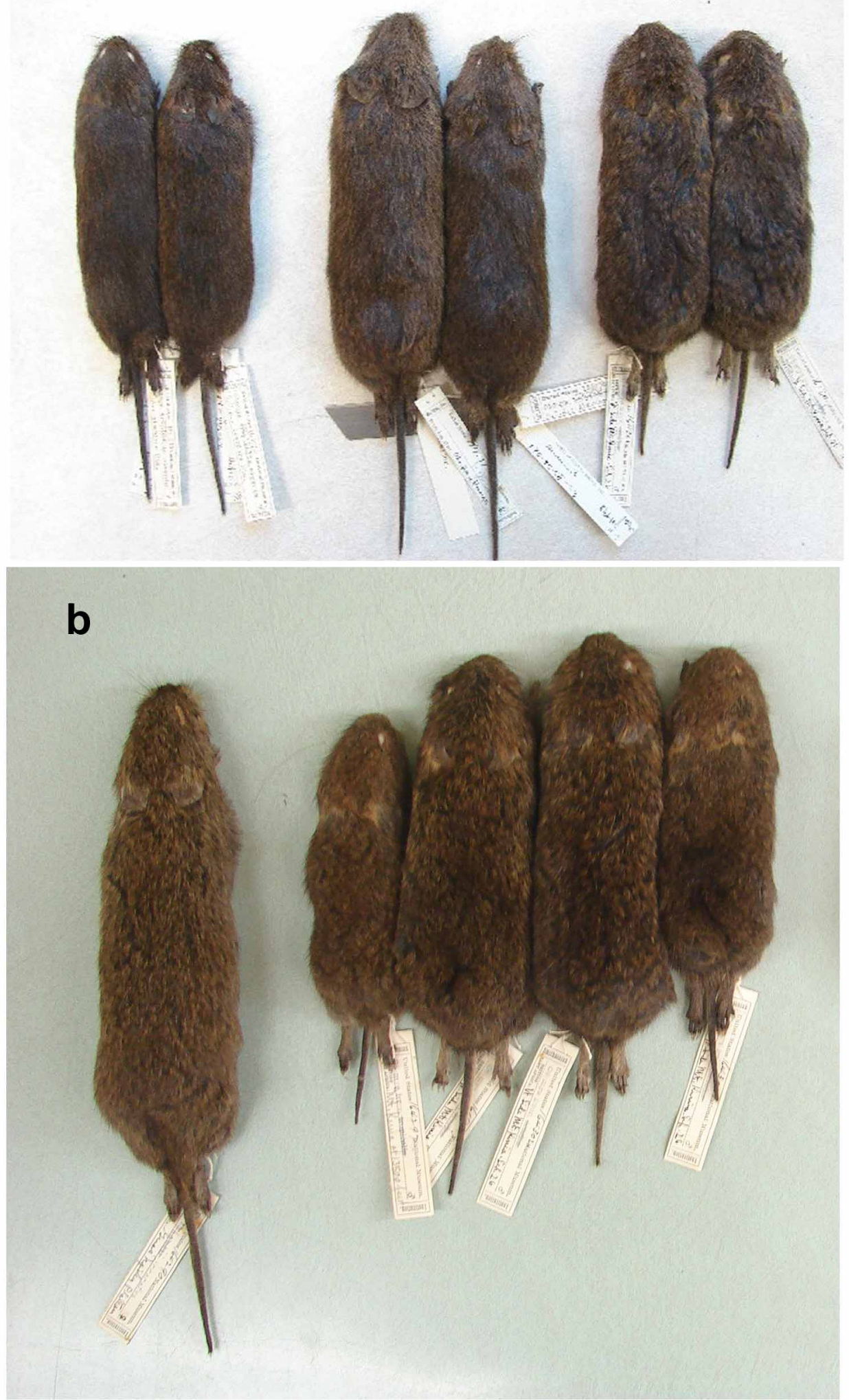

FIGURE 16. Photographs a) comparing pairs of study skins from three populations in the Aberdares: O. tropicalis (from midaltitudes, two skins on left, and summit, two skins in middle) and $O$. orestes (two skins on right); and (b) comparing $O$. thomasi (left) with series of $O$. orestes (right). Apparent differences in size are not due to over-stuffing of specimens but more or less indicative of real size difference as can be verified from inspection of means of head and body length of relevant taxa in Table 9 
whilst $O$. typus s.s. and $O$. fortior occur to the west of the Rift valley. Whilst $O$. typus s.s. is known from alpine moorlands, fortior occupies lower-lying forests in the southwestern parts of Ethiopia and is almost completely differentiated morphometrically from O. typus s.s. populations. Lavrenchenko et al. (1997) already demonstrated the genetic distinctness (on allozyme data) of $O$. yaldeni sp. nov. (= "Sp. A") occurring sympatrically with $O$. helleri (= "Sp. B") on the Bale Mountains. Thus, we feel justified in recognised six distinct species in Ethiopia on a combination of karyotypic, molecular, craniodental, morphometric, biogeographic and ecological data (see Taxonomic Summary below).

Our study was not intended to focus upon the $O$. tropicalis species complex as currently understood (i.e., sensu Musser \& Carleton 2005; Carleton \& Byrne 2006). Although long confused as a subspecies of O. irroratus (Thomas, 1902b; Bohmann, 1952), subsequent studies drawing upon morphological, morphometric, and genetic information have underscored that $O$. tropicalis of eastern Africa is specifically distinct from $O$. irroratus of southern Africa (Taylor \& Kumirai 2001; Carleton \& Byrne 2006; Taylor et al. 2009a; see Fig. 3a, b). Nonetheless, these latter studies and results presented herein reveal that $O$. tropicalis actually refers to a complex of species. Taxonomic problems encountered and some profitable lines of inquiry follow.

At least three divergent "tropicalis" cyt $b$ clades are apparent (Fig. 3a). One includes topotypic series of tropicalis from Mt Kenya, as well as slightly divergent (genetically and morphometrically) Aberdares populations; a heterogenous mixture of forms from Ruhuruini in the Aberdares (O.t. tropicalis?), from Mt Elgon (O.t. elgonis?), and from Rethy in the northeastern DRC (O.t. faradjius) comprises a second; and a third unites individuals from the bamboo zone of Mt Elgon (O.t. elgonis?). Although our results are preliminary, we note that these different moieties within "tropicalis" link at various levels of kinship with taxa formerly classified as subspecies under $O$. typus (O. dartmouthi, O. jacksoni, O. orestes). To resolve the tropicalis complex properly will require further molecular and morphometric studies that broaden geographical sampling, survey elevational transects on a finer scale, and incorporate topotypic material in deliberate taxonomic comparisons. Our study notably lacks genetic data for populations that inhabit mountains along the Albertine Rift (rubeculus, vulcanis), the Imatong Mts in southern Sudan (giloensis, reallocated to O. tropicalis s.l. by Carleton \& Byrne 2006), or ranges that outlie the core highlands bordering the eastern Rift Valley (nubilus, vivax). Specimens obtained from detailed transects along the slopes of East Africa's higher mountains would do much to illuminate the status of taxa currently assigned to $O$. tropicalis, in particular the middle elevation form elgonis. Specimens nominally referrable to the latter form are scattered in the gene tree produced from cyt $b$ sequences (Fig. 3a), a result that leaves us uncertain about which ones actually represent $O$. tropicalis elgonis proper as known from its type locality (Elgonyi, Mt Elgon).

The variable occurrence of $5 \mathrm{~m} 1$ laminae in certain localities of $O$. tropicalis from the Aberdare Mts is a surprizing finding in view of the remarkable stability of this character observed in most species of Otomys (4 m1 laminae), including taxa synonymized under $O$. tropicalis s.l. (Table 4). The occasional report of $O$. lacustris in central Kenya (Taylor \& Kumirai 2001) is based on one of these exceptional specimens with a 5-laminated m1 (BM 10.5.3.480). Possession of a lower first molar with 5 laminae figured prominently in the diagnoses of other east African species (i.e., O. barbouri, O. lacustris), but the Aberdares sample (OTU 11) is morphometrically well differentiated from those forms (Fig. 10). Instead, it morphologically and morphometrically fits with other OTUs here referred to O. tropicalis and as earlier identified by others (Hollister 1919; Carleton \& Byrne 2006). Two specimens (USNM 590002, 590003) from one locality where m1 variation was encountered (Aberdares National Park, Fishing Lodge) genetically clustered with other O. tropicalis from the Aberdare Mts and Mt Kenya (Fig. 3a, b); unfortunately, both retain the common 4-laminated $\mathrm{m} 1$ character state. Do individuals with $5 \mathrm{~m} 1$ laminae form a cryptic species that is otherwise morphometrically indistinguishable from $O$. tropicalis, or do they represent population variation which may or may not be indicative of incipient speciation, paralleling the evolution of forms with $5 \mathrm{~m} 1$ laminae on Mt Elgon (O. barbouri) and the Eastern Arc Mountains (O. lacustris)? Answers to these questions must incorporate fresh material collected along carefully designed elevational transects in the Aberdare Mts.

In discussing the southern geographic limits of O. tropicalis, Carleton \& Byrne (2006) suggested that sungae, described from the Usambara Mts of the northern Eastern Arc Mts and previously assigned to the $O$. denti group based on morphology (see Taylor et al. 2009a), could as reasonably be assigned to the tropicalis group on biogeographical and morphological grounds. Cytochrome $b$ data unequivocally support this hypothesis (Fig. 3a), grouping near-topotypic $O$. sungae within a clade comprising $O$. jacksoni, O. orestes, and the small-sized molecular clade of tropicalis s.l. discussed above. As already proposed by Taylor et al. (2009a), O. sungae is a good species; however, the topotypic population from the Usambaras is clearly genetically remote from the lineage from the 
Nyika Plateau formerly assigned to $O$. denti sungae (Musser \& Carleton 2005, Fig. 3 a, b). Taylor et al. (2009a) already raised this possibility based on biogeographical and morphometric data but, pending molecular data, refrained from formally describing this lineage. The evidence at hand, from this study and that of Taylor et al., (2009a), makes it abundantly clear that the name O. sungae should be reserved only for the Usambaras population and that the lineage from the Nyika Plateau (which groups genetically with two divergent lineages of $O$. lacustris) should be formally described as new (with no available names in the literature).

Speciation, adaptive divergence, and patterns of microendemism. Palaeontological data support a South African origin and early Pliocene radiation of Otomyini (Denys 1989, 1999, 2003; Pocock 1976, 1987; Senegas 2001; Senegas \& Avery 1998). Two fossil species of Euryotomys from South Africa, E. pelymoides (Pocock 1976; 3.7-5 Myr; Denys et al. 1989) and E. bolti (Senegas \& Avery 1998; 4-5 Myr; Senegas 2001), provide evidence for the murine origin of Otomyini. The oldest fossils of true Otomys appear around 3-3.7 Myr in South Africa (O. cf. gracilis and $O$. cf. sloggetti) but not until 2.3 Myr in the western Rift Valley (eastern DRC; Otomys sp.) and 1.5-2.0 Myr in East Africa (O. petteri and $O$. cf. petteri; Denys 1989, 2003), despite excellent micromammal fossil records from older sequences in east Africa.

As discussed in depth by Taylor et al. (2004b), Bohmann's (1952) adaptive scenarios emphasized the evolutionary trend towards increasing lamina number in M3 in successively derived taxa, surmising that multiple southnorth African radiations occurred that coincided with cooler Pleistocene "pluvial" (glacial) periods. Specifically, Bohmann (1952) proposed that $O$. sloggetti radiated north to give rise to $O$. denti in the western (Albertine) Rift highlands during an early Pleistocene pluvial, South African $O$. saundersiae radiated north to give rise to Ethiopian $O$. typus during a subsequent pluvial, whereas South African $O$. irroratus gave rise to east African $O$. tropicalis during a third pluvial cycle. On the other hand, based on palaeontological evidence, Denys (2003) postulated a single northern dispersal of the extinct $O$. cf. gracilis first to the western Rift mountains (Otomys sp; $2.3 \mathrm{Myr}$ ) and then subsequent in situ speciation in East Africa, giving rise inter alia to the extinct $O$. petteri (from $1.8 \mathrm{Myr}$ at Olduvai) and $O$. cf. angoniensis (0.3 Myr).

The earliest diversification within Otomyini estimated at around 3.5 Myr (Fig. 3a), which separates East African O. denti-lacustris, O. barbouri and South African P. brantsii from other southern, western, northern and eastern lineages, is consistent with the earliest fossil appearance of Otomys (O. cf. gracilis) in the Upper Pliocene deposits at Makapansgat (3.5-3.7 Myr; Pocock 1987), possibly indicative of a single or multiple simultaneous northwards, westward and eastwards dispersals from South Africa as predicted by Denys (2003). Two events dated at around 3.1 Mya resulted in splits in the former clade between the denti-lacustris clade and O. barbouri and P. brantsii; and in the latter clade, the split between $O$. angoniensis and $O$. irroratus from South Africa and all other East and West African taxa (occidentalis, burtoni, tropicalis s.l., typus s.1., sungae). At approximately $2.8 \mathrm{Myr}$ ago the Ethiopian O. typus s.l. clade diverged from the remaining East and West African clades followed by the split around $1.8 \mathrm{Myr}$ between $O$. occidentalis and $O$. burtoni, and between a clade comprising $O$. tropicalis s.s., $O$. tropicalis (Aberdares) and $O$. dartmouthi (Burundi and DRC) from a clade constituting $O$. zinki (Mt Kilimanjaro), $O$. simiensis sp. nov. (Simien Mts), O. sungae (Usambaras), O. jacksoni (Mt Elgon), O. orestes (Abedares moorland), the two divergent clades of $O$. tropicalis "elgonis" (Mt. Elgon) and O. t. faradjius from the DRC. Divergence of a number of more terminal lineages: 1) tropicalis s.s from dartmouthi; 2) O. zinki from O. typus s.1. [O. simiensis $\mathbf{\text { sp. }}$ nov.]; 3) O. sungae from a clade comprising O. jacksoni, O. tropicalis “elgonis “ and O. t. faradjius, took place close to $1 \mathrm{Mya}$, a time which corresponds closely with a hypothesized period of aridification in the region. Congruent speciation pulses are apparent in the $O$. denti-lacustris clade, the Ethiopian clade (O. typus s.s. and $O$. helleri) and these lineages splitting off from $O$. fortior (southwestern forests) as well as in other mammal and bird taxa (Bowie et al. 2004, 2006; DeMenocal 1995, 2004; Huhndorf et al. 2007; Taylor et al. 2009a).

As anticipated by Denys (2003) and Carleton \& Byrne (2006), patterns of morphometric, genetic and ecological divergence amongst East African populations of the $O$. tropicalis s.l. and $O$. typus s.l. complexes are more parsimoniously explained by regional cladogenesis along elevational gradients, rather than by multiple successive continental colonisations of different ancestral forms as supposed by Bohmann (1952). Clearly the "alpine morph" of $O$. typus s.l. has evolved independently at very high elevations on several mountain ranges in eastern and northeastern Africa. The strong support for monophyly of two divergent lineages (O. jacksoni from the alpine zone and one sub-alpine/montane lineage assigned previously to $O$. tropicalis elgonis) occurring on Mt Elgon provides direct corroboration of this hypothesis of in situ speciation along an elevational gradient. Otomys orestes from the Kenyan Highlands is also included in this clade (Clade 3b of Fig. 3a), suggesting continuity of habitats between Mt 
Elgon and the Kenyan Highlands at around 0.5 Myr (based on dating estimates from BEAST; Fig. 3a). On the other hand, the existence of a divergent "elgonis" clade in Clade 2 (Fig. 3a) and the unresolved but basal position within Otomyini of another Mt Elgon endemic, O. barbouri, suggests that independent radiations on Mt Elgon have occurred widely separated in time. However, it should be noted that the combined 12S rRNA/ cyt $b$ tree (Fig. 3b) provides strong support for monophyly of the two divergent $O$. t. elgonis clades, which form separate clades based only on cyt $b$ sequences (Fig. 3a). Thus, further molecular data may indeed more strongly validate the hypothesis of multiple speciation events occurring in situ along elevational transects on Mt Elgon.

As in the case of $O$. barbouri, members of the O. denti-lacustris complex from the Albertine Rift, Southern Rift and Eastern Arc Mts-all characterised by ancestral morphological characters, such as fewer M3 laminae, blackish coloration, and single-grooved lower incisors-seem to occupy a more basal origin in the radiation of eastern African species (Fig. 3a, b; see also Taylor et al. 2009a).

As reasoned by Carleton \& Byrne (2006:504-510), the biodiversity of Otomyini within eastern Africa has been chronically underestimated since Bohmann's (1952) revision. The results of this study appreciably elevate the number of endemic Otomys species (of the O. typus s.l. and O. tropicalis s.l. complexes) known from eastern and northeastern Africa: Ethiopian Highlands (six taxa including O. fortior, O. helleri, O. typus s.s., and the three new species described formally below, $O$. cheesmani $\mathbf{s p . ~ n o v . , ~ O . ~ s i m i e n s i s ~ s p . ~ n o v . ~ a n d ~} O$. yaldeni $\mathbf{s p .}$ nov.); Eastern Arc Mts and Southern Highlands of Tanzania and Nyika Plateau of Malawi (O. uzungwensis, two lineages obscured within $O$. lacustris, $O$. sungae, and the Nyika population previously assigned to $O$. denti sungae); Ruwenzori Mts (O. dartmouthi, O. denti, O. tropicalis s.1.); Mt Elgon (O. jacksoni, O. barbouri, and perhaps two unnamed lineages previously assigned to $O$. tropicalis elgonis); the Mau Escarpment and Uasin Gishu Plateau (O. thomasi, O. tropicalis s.1.); Aberdares and Mt Kenya (O. orestes, O. tropicalis s.s.); the Mathews Range (O. dollmani; see Carleton \& Byrne 2006); and Mt Kilimanjaro (O. zinki). Detailed molecular, cytogenetic, and morphological analyses of populations belonging to the $O$. angoniensis complex, distributed on lower mountain slopes in Kenya and Tanzania, may reveal other geographically restricted species of Otomys that would enhance estimates of species richness and endemism within the region.

Given the highly microendemic status of most of the above-mentioned species and their restriction to localized alpine or subalpine habitats, threats such as climate change and/or anthropogenic effects (e.g., extensive fires caused by poachers in the alpine zone of Mt Elgon; PJT personal observation) may result in high extinction risks and red-listing as Endangered or Critically Endangered taxa.

\section{Taxonomic summary}

The following accounts formalize our results and taxonomic recommendations that involve species-group epithets formerly classified within O. typus sensu Bohmann (1952), Misonne (1974), and others. In view of the many forms herein considered and inconsistent interpretations of their status and affinity by past systematists, we present full synonymies that trace earliest identifications, primary synonyms, and subsequent name combinations as used in major classifications, faunal reports, and taxonomic revisions and compendia. Specimens examined include all individuals personally seen and identified by us. More detailed diagnoses and descriptions are provided for the three species herein described: $O$. yaldeni $\mathbf{s p . ~ n o v . , ~} O$. cheesmani $\mathbf{s p . ~ n o v . ~ a n d ~} O$. simiensis sp. nov.

\section{Otomys cheesmani new species}

Figs 5, 6, 17; Table 9

Cheesman's Vlei Rat

Holotype. BMNH 1937.2.24.84; adult male, dry skin and skull, collector's number 7400; collected by R.E. Cheesman, 20 October 1937.

Type locality. Ethiopia, vicinity of Dangila, $66 \mathrm{~km} \mathrm{~S} \mathrm{Lake} \mathrm{Tana,} 2100 \mathrm{~m} ; 11^{\circ} 16^{\prime} \mathrm{N}, 36^{\circ} 51^{\prime} \mathrm{E}$.

Diagnosis. The largest representative of the Otomys typus species complex, differing from all other members by its distinctly larger and more robust skull with short and broad nasal bones, broad, angular and thickened zygomatic arches, very well developed supraorbital and parietal ridges and relatively very narrow interorbital region (referred to "Sp. C" above; see Figs 5, 6, 17 and Tables 7, 9). 
Paratypes. BMNH 28.1.11.117 (adult female, dry skin and skull, collector's number 6040), BMNH 28.1.11.174 (adult male; dry skin and skull, collector's number 6078), BMNH 28.1.11.175 (subadult male, dry skin and skull), BMNH 28.1.11.176 (subadult male, dry skin and skull, collector's number 6366), BMNH 28.1.11.177 (adult female; dry skin and skull, collector's number 6040), BMNH 28.1.11.178 (adult female, dry skin and skull, collector's number 6070), BMNH 28.1.11.179 (adult female, dry skin and skull, collector's number 6165), BMNH 1937.2.24.82 (adult male, dry skin and skull, collector's number 7383), BMNH 1937.2.24.83 (adult male, dry skin and skull, collector's number 7387), BMNH 1937.2.24.85 (adult male, dry skin and skull, collector's number 7404), BMNH 1937.2.24.86 (adult female, dry skin and skull)—all 11 from the type locality, collected by R.E. Cheesman between 1926 and 1937; BMNH 70.657 (Ethiopia, Gojam, Debra Marcos, 2500 m; 10²0’ N, 37²6'E; collected by Great Abbai Expedition, 19 August 1968).

Description. The dorsal pelage of $O$. cheesmani is bright brown with a reddish shade. Ventral pelage is pale yellowish-grey, the individual hairs yellow tipped and grey at the base. The ears are blackish, their inner surface covered with short rufous hairs. The dorsal surface of the forefeet and hindfeet is dark grey; the claws are grey. The tail is relatively short (49.3\% of HB). The caudal hairs are blackish on the upper surface and pale yellowish on the lower surface; however, the tail does not appear distinctly bicoloured.

The robust skull of $O$. cheesmani (Fig. 17) is reflected in the large means recorded for most cranial dimensions, which exceed those of all other representatives of the O. typus complex except for interorbital width (Table 9). Although the observed ranges of certain external and cranial variables overlap, four cranial variables do not overlap in size: GLS (43.3-48.2 mm versus 34.3-43.3 mm); MXTL (11.0-12.0 mm versus 8.1-10.5 mm); NAW (8.0-9.0 $\mathrm{mm}$ versus 5.8-8.0 mm); PL (23.6-26.2 mm versus 16.7-23.6 mm) (Table 9). The anterior face of the lower incisor has two well defined and equally deep grooves. The upper third molar has 8 or 9 complete laminae (9 in the holotype) and the lower first molar 4 complete laminae.

Distribution. Known only from two localities in northwestern Ethiopia, 2100-2500 m (see above).

Ecology. The type locality currently represents a true agricultural landscape, presumably much transformed from the time when Cheesman collected the series. The holotype and paratypes of $O$. cheesmani were supposedly collected in an intrazonal wetland habitat. The specimen from Debra Marcos (BMNH 70.657) was captured in low Acacia scrub. Otomys cheesmani occupies lower elevations (2100-2500 m) than other Ethiopian Otomys (excluding the rainforest dweller $O$. fortior). Nevertheless, habitat requirements of this new species remain unclear.

Etymology. We selected the specific epithet to recognize Robert E. Cheesman (1878-1962), who collected the holotype and topotypic series of this distinctive species of Otomys. Cheesman was a British military and diplomatic officer in the Middle East, Arabian Peninsula, and nearby Africa, and like many other professionals of this era, he developed broad interests in the geography and natural history of the lands where he worked. During his service as Consul in North-West Abyssinia, Cheesman not only explored the source of the Blue Nile and surveyed its course from Lake Tana to the Sudan border (Lake Tana and the Blue Nile: An Abyssinian Quest by R. E. Cheesman, 1936; Macmillan: London, 400 pp.), but also found time to collect bird and mammal specimens for the British Museum. The species name combines the surname Cheesman and genitive singular case-ending "i" indicative of masculine gender.

\section{Otomys dartmouthi Thomas, 1906b}

Otomys dartmouthi; Thomas, 1906b:141 (type locality—Uganda, Ruwenzori East, Mubuku Valley, 12,500 ft [3810 m]; holotype-BMNH 6.7.1.64); Dollman, 1915:166 (taxonomic revision, retained as species); Allen, 1939:344 (listed as valid species); Ellerman, 1941:322 (listed as valid species); Musser \& Carleton, 2005:1526 (reinstated as valid species).

Otomys typus dartmouthi; Bohmann, 1952:43 (taxonomic revision, new name combination, retention as valid subspecies).

Otomys typus [dartmouthi]; Misonne, 1974:33 (listed in synonymy without indication of rank); Musser \& Carleton, 1993:682 (listed in synonymy without indication of rank).

Otomys irroratus [dartmouthi]; Delany, 1975:53 (faunal work, new name combination, listed in synonymy without indication of rank).

Distribution. Alpine habitats, ca. 3300-4400 m, of the Ruwenzori Mountains, southwestern Uganda and contiguous eastern D.R. Congo.

Specimens examined. D.R. CONGO: Blanc (RMCA 1095); Kalindera Masereka (RMCA 82011-M827); Virungas, Albert National Park, Wusuwameso, 4380 m (RMCA 82011-M830, 82011-M831). UGANDA: Ruwen- 
zori East, Mubuku Valley, 12,500 ft (3810 m) (BMNH 6.7.1.62-6.7.1.65); Kasese District, Ruwenzoris, left bank Bujuku River, 11,050 ft (3368.04 m) (FMNH 144327, 144328, 144330); Kasese District, Ruwenzoris, above Lake Bujuku, 13,050 ft (3977.64 m) (FMNH 144334-144336, 144338, 144341, 144342).

\section{Otomys fortior Thomas, 1906a}

Otomys typus fortior; Thomas, 1906a:302 (type locality—Ethiopia, Kaffa, Charada Forest, $6000 \mathrm{ft}$ [1829 m]; holotypeBMNH 6.11.1.29); Allen, 1939:348 (listed as valid subspecies); Ellerman, 1941:321 (listed as valid subspecies); Bohmann, 1952:45 (taxonomic revision, retained as valid subspecies).

Otomys fortior; Dollman, 1915:170 (taxonomic revision, elevation to species).

Otomys typus [fortior]; Misonne, 1974:33 (listed in synonymy without indication of rank); Yalden et al., 1976:56 (faunal work, listed in synonymy without indication of rank); Musser \& Carleton, 1993:682, 2005:1530 (listed in synonymy without indication of rank).

Distribution. Restricted to montane evergreen forests in the southwestern regions of Ethiopia (see OTU 2 in Fig. 1a). Although specimens from Jimma are assigned provisionally to $O$. fortior based on geographic and ecological proximity, we note that morphometrically this series is characterized by large cranial size making them comparable with specimens from "Sp. C" from the Lake Tana region of central Ethiopia.

Specimens examined. ETHIOPIA: Kaffa, Charada Forest, 6,000 ft (1828.8 m) (BMNH 6.11.1.29); Beletta Forest (ZMMU 164960-164965, 166072); Sheko Forest (ZMMU 167310); Oromiya, Jimma, 1750 m (USNM 515058-515064, 516317, 516507); Inegawa Forest, 20 km N of Tepi, 2340 m (ZMMU 181665-181667).

\section{Otomys helleri Frick, 1914, new rank}

Otomys jacksoni helleri; Frick, 1914:10 (type locality_Abyssinia [Ethiopia], Chilalo Divide Camp, 9000 ft [2743 m]; holotype-CM 3519); Allen, 1939:345 (listed as valid subspecies); Ellerman, 1941:322 (listed as valid subspecies).

Otomys typus helleri; Bohmann, 1952:44 (taxonomic revision, new name combination, retained as valid subspecies).

Otomys typus [helleri]; Misonne, 1974:33 (listed in synonymy without indication of rank); Yalden et al., 1976:56 (faunal work, listed in synonymy without indication of rank); Musser \& Carleton, 1993:682, 2005:1530 (listed in synonymy without indication of rank).

Otomys jacksoni malkensis; Frick, 1914:11 (type locality—Abyssinia [Ethiopia], Sidamo, Malka; holotype-CM 3433); Allen, 1939:345 (listed as valid subspecies); Ellerman, 1941:322 (listed as valid subspecies).

Otomys typus malkensis; Bohmann, 1952:43 (taxonomic revision, new name combination, retained as valid subspecies).

Otomys typus [malkensis]; Misonne, 1974:33 (listed in synonymy without indication of rank); Yalden et al., 1976:56 (faunal work, listed in synonymy without indication of rank); Musser \& Carleton, 1993:682, 2005:1530 (listed in synonymy without indication of rank).

Distribution. Alpine habitats in Bale Mountains and Arussi Plateau, possibly extending southwards to include localities such as Malka (see OTU 3 in Fig. 1a).

Specimens examined. ETHIOPIA: Arussi Plateau, Mount Albasso (BMNH 29.11.7.82, 29.11.7.83; FMNH 28125, 28126, 28129, 28132-28139, 28159-28164; USNM 259506); Bale Mountains (BMNH 72.1229, 72.1300, 72.1302, 72.1304, 72.1307, 72.1308; LM 1986-212-6; SM 23340; ZMMU 162595-162601); Bale Mountains, Dinsho (MNHN 1972.218-1972.228; MCZ 57319); Chilalo (SM 35868, 35876, 35877, 35879, 35883, 35887).

\section{Otomys jacksoni Thomas, 1891}

Otomys jacksoni; Thomas, 1891:184 (type locality-Uganda, crater of Mount Elgon, 13,200 ft [4023 m]; holotype-BMNH 93.2.3.34); Wroughton, 1906: 276 (retained as valid species); Dollman, 1915:167 (taxonomic revision, retained as valid species); Lawrence \& Loveridge, 1953:59 (faunal report, recognition as valid species); Musser \& Carleton, 2005:1527 (reinstated as valid species).

Otomys jacksoni jacksoni; Allen, 1939:345 (listed as valid species and subspecies); Ellerman, 1941:322 (listed as valid species and subspecies).

Otomys typus jacksoni; Bohmann, 1952:43 (taxonomic revision, new name combination, retained as valid subspecies) 
Otomys typus [jacksoni]; Misonne, 1974:33 (listed in synonymy without indication of rank); Yalden et al., $1976: 56$ (faunal work, listed in synonymy without indication of rank); Musser \& Carleton, 1993:682 (listed in synonymy without indication of rank).

Otomys irroratus [jacksoni]; Delany, 1975:53 (faunal work, new name combination, listed in synonymy without indication of rank).

Distribution. Alpine zone, 3300-4200 m, of Mount Elgon, straddling the border of southeastern Uganda-westcentral Kenya.

Specimens examined. UGANDA: Mount Elgon, crater, 3300-4200 m (BMNH 93.2.3.34, 2.9.9.19, 35.2.22.37, 35.2.22.38); Mount Elgon, Kaburomi (MCZ 31368); Mount Elgon, Mude Cave camp, 3600 m (DM $6261)$.

\section{Otomys orestes Thomas, 1900}

Otomys irroratus orestes; Thomas, 1900:175 (type locality—Kenya, Mount Kenya, Teleki Valley, 13,000 ft [3962 m]; holotype-BMNH 1900.2.1.21); Wroughton, 1906:275 (listed as valid subspecies).

Otomys orestes orestes; Dollman, 1915: (new name combination, elevation to species, de facto arrangement as nominate subspecies); Allen, 1939:346 (listed as valid species and subspecies); Ellerman, 1941:323 (listed as valid species and subspecies); Setzer, 1953:334 (taxonomic description, retained as valid species and subspecies).

Otomys orestes; Hollister, 1919:147 (faunal report, retained as monotypic species); Musser \& Carleton, 2005:1528 (reinstated as species, indication of synonyms); Carleton \& Byrne, 2006:497 (taxonomic revision, retained as species).

Otomys typus orestes; Bohmann, 1952:41 (taxonomic revision, new name combination, retained as valid subspecies).

Otomys typus [orestes]; Misonne, 1974:33 (listed in synonymy without indication of rank); Musser \& Carleton, 1993:682 (listed in synonymy without indication of rank).

Otomys thomasi malleus; Dollman, 1915:154 (type locality—British East Africa [Kenya], Naivasha Province, Lake Olbollossat; holotype-BMNH 12.7.1.431); Allen, 1939:346 (listed as valid subspecies); Ellerman, 1941:323 (listed as valid subspecies).

Otomys typus malleus; Bohmann, 1952:42 (new name combination, retained as valid subspecies).

Otomys typus [malleus]; Misonne, 1974:33 (listed in synonymy without indication of rank); Musser \& Carleton, 1993:682 (listed in synonymy without indication of rank).

Otomys orestes [malleus]; Musser \& Carleton, 2005:1529 (new name combination, listed in synonymy without indication of rank).

Otomys percivali; Dollman, 1915:168 (type locality—British East Africa [Kenya], Naivasha District, 12 mi S Lake Olbollossat, $8700 \mathrm{ft}$ [2652 m]; holotype-BMNH 12.7.1.424); Allen, 1939:346 (listed as valid species); Ellerman, 1941: 322 (listed as valid species).

Otomys typus malleus; Bohmann, 1952:42 (taxonomic revision, new name combination, percivali allocated as full synonym, invalid as subspecies).

Otomys typus [percivali]; Musser \& Carleton, 1993:682 (listed in synonymy without indication of rank).

Otomys orestes [percivali]; Musser \& Carleton, 2005:1529 (new name combination, listed in synonymy without indication of rank).

Otomys thomasi squalus; Dollman, 1915:155 (type locality—British East Africa [Kenya], Aberdare Range, Mount Kinangop, 12,000 ft [3658 m]; holotype-BMNH 10.5.3.41); Hollister, 1919:147 (faunal report, listed as valid subspecies); Allen, 1939:347 (listed as valid subspecies); Ellerman, 1941:323 (listed as valid subspecies).

Otomys typus squalus; Bohmann, 1952:41 (taxonomic revision, new name combination, retained as valid subspecies).

Otomys typus [squalus]; Misonne, 1974:33 (listed in synonymy without indication of rank); Musser \& Carleton, 1993:682 (listed in synonymy without indication of rank).

Otomys orestes [squalus]; Musser \& Carleton, 2005:1529 (new name combination, listed in synonymy without indication of rank).

Distribution. Discontinuous in alpine settings, ca. 2700-4200 m, on Mount Kenya and the Aberdare Mountains, central Kenya.

Specimens examined. KENYA: Aberdare Mountains, summit, 11,000 ft (USNM 184033-184035), 12,500 ft (3810 m) (AMNH 80995); Aberdare Mountains, moorland (RMCA a1.008-M-1123); Aberdares, Mount Kinangop, 12,000 ft (3658 m) (BMNH 10.5.3.41); Aberdare National Park, Fishing Lodge, 8,760, 9,000, and 9,500 ft (2670, 2743, and 2896 m) (USNM 589995-589997); Naivasha District, Lake Ol Bolossot (BMNH 12.7.1.431); Naivasha District, 12 mi S Lake Ol Bolossot, 8,700 ft (2652 m) (BMNH 12.7.1.424); Mount Kenya, Teleki Valley, 13,000 ft (3962 m) (BMNH 1900.2.1.21); Mount Kenya, west side, 10,700 ft (3261 m) (FMNH 43819, 43444; USNM 164308, 164346, 164357, 164358), 13,500 ft (4115 m) (USNM 164293-164295, 164297, 164329, 164332 
164334), 13,700 ft (4157 m) (FMNH 43445, 43446; USNM 164300-164305, 164344, 164345), 14,600ft (4450 m) (AMNH 80993), 15,000 ft (4572 m) (AMNH 82605-82607).

\section{Otomys simiensis new species}

Figs. 2c, 5, 6, 17; Table 9

Simien Vlei Rat

Holotype. ZMMU 178757; adult male, dry skin and skull, collector's number 1338; collected by L.A. Lavrenchenko, 4 May 2005.

Type locality. Ethiopia, Simien Mountains National Park, vicinity of Sankaber campsite, $3250 \mathrm{~m} ; 1^{\circ} 14^{\prime} \mathrm{N}$, $38^{\circ} 03^{\prime} \mathrm{E}$ (GPS reading by collector).

Diagnosis. A small-sized representative of the O. typus species complex (referred to "Sp. D" above; see Figs. 5, 6, 17 and Tables 7, 9). Similar to $O$. yaldeni but considerably larger externally (HB mean $155 \mathrm{~mm}$ in simiensis, cf. 143 in yaldeni; tail means $83 \mathrm{~mm}$ and $72 \mathrm{~mm}$ respectively); skull having a narrower interorbital region, less pronounced supraorbital ridges, relatively longer nasal bones, and braincase with flatter dorsal profile (Fig. 17); karyotype distinctive $(2 \mathrm{~N}=54, \mathrm{NF}=56)$.

Paratypes. ZMMU 178756 (adult female, dry skin and skull, collector's number 1336); ZMMU 178758 (adult male, dry skin and skull, collector's number 1352); ZMMU 178759 (adult male, dry skin and skull, collector's number 1353); ZMMU 178762 (adult female, dry skin and skull, collector's number 1429); all four specimens from the type locality, collected by L.A. Lavrenchenko between 4 and 20 May 2005.

Description. The dorsal pelage is dark brown, with individual hairs having a blackish base, rufous subterminal band, and relatively narrow black tip. Among the guard hairs $(17 \mathrm{~mm})$, there are longer bristles $(26 \mathrm{~mm})$ that produce the effect of the double-layered fur. Ventral pelage is pale grey, the individual hairs grey at the base and tipped with pale whitish. The ears are blackish, their inner surface covered with short rufous hairs. Dorsal surfaces of the forefeet and hindfeet are dark grey, and the claws are grey. The tail is moderately long (53.4\% of HB) and appears distinctly bicoloured, the dorsal caudal hairs relatively long and blackish in contrast to the white ventral hairs.

The skull resembles most other members of the O. typus complex, having a relatively narrow interorbital region, reduced supraorbital ridges, shallow braincase, and short anterior palatal foramen (Table 9). Anterior face of the lower incisor has two well defined and equally deep grooves. The upper third molar possesses 7 complete laminae; the lower first molar possesses 4 complete laminae.

The chromosomal complement of $O$. simiensis consists of $2 \mathrm{~N}=54, \mathrm{NF}=56 ; 2 \mathrm{~m}+52 \mathrm{a}$ (Fig. $2 \mathrm{c}$ ).

Otomys simiensis differs from other Ethiopian Otomys (excluding yaldeni) by the lower number of laminae in the upper third molar (7 versus 8-9) and the double-layered dorsal fur. Amongst other members of typus s.1., simiensis is most like jacksoni which is similar in skull size and shape (Table 9) and also has 7 laminae in the third upper molar and a similar dark brown colour (Bohmann 1952); however, jacksoni is much smaller in external dimensions (HB mean $141 \mathrm{~mm}$ in jacksoni cf. $155 \mathrm{~mm}$ in simiensis) and has a proportionately shorter tail (45.4\% in jacksoni cf. 53.4\% in simiensis). Furthermore molecular data (Fig. 3) clearly demonstrate the genetic separation of these taxa.

Distribution. Known only from the type locality in the Simien Mountains, northern Ethiopia (see above).

Ecology. The holotype and paratypes of O. simiensis were captured in tree-heather forest (trees: Erica arborea, Hypericum revolutum; shrub: Rosa abyssinica) with open grassy patches. At higher altitudes, this species is replaced by $O$. typus s.s., a common inhabitant of the afroalpine zone in the Simien Mountains National Park (e.g., Chennek area, $\left.13^{\circ} 15^{\prime} \mathrm{N}, 38^{\circ} 13^{\prime} \mathrm{E}, 3800 \mathrm{~m}\right)$.

Etymology. The rugged Simien Mountains, to which the new species is apparently endemic, dominate the northern plateau of Ethiopia and contain its highest peaks. The name combines the stem Simien with the Latin suffix "ensis," meaning "native of" or "characteristic of" the place indicated by the stem.

\section{Otomys thomasi Osgood, 1910}

Otomys thomasi; Osgood, 1910:9 (type locality—British East Africa [Kenya], Molo; holotype-FMNH 16698).

Otomys thomasi thomasi; Dollman, 1915:153 (taxonomic revision, retained as species, de facto arrangement as nominate sub- 
species); Hollister, 1919:147 (faunal report, listed as valid species and subspecies); Allen, 1939:346 (listed as valid species and subspecies); Ellerman, 1941:323 (listed as valid species and subspecies).

Otomys typus thomasi; Bohmann, 1952:41 (taxonomic revision, new name combination, retained as valid subspecies).

Otomys typus [thomasi]; Misonne, 1974:33 (listed in synonymy without indication of rank); Musser \& Carleton, 1993:682 (listed in synonymy without indication of rank).

Otomys orestes [thomasi]; Musser \& Carleton, 2005:1529 (new name combination, listed in synonymy without indication of rank); Carleton \& Byrne, 2006:497 (taxonomic revision, retention of thomasi as junior synonym).

Distribution. High plateau and mountains that form the western border of the Rift Valley (eastern branch), central Kenya; elevational range ca. 2450-2750 m.

Specimens examined. KENYA: Uasin Gishu Plateau, $32 \mathrm{~km} \mathrm{~N}$ Eldama Ravine, 9,000 ft (2743 m) (USNM 164290); Molo (FMNH 16693-16695, 16698, 16699).

\section{Otomys typus (Heuglin, 1877)}

Oreomys typus; Heuglin, 1877:76; Thomas, 1891:185 (new species description of Otomys, retention of typus in separate genus).

Otomys degeni; Thomas, 1902a:311 (type locality—Abyssinia [Ethiopia], Shoa, Gombitchu, 8,000 ft (2438 m); holotypeBMNH 2.9.9.19).

Otomys typus; Wroughton, 1906:276 (new name combination, listed as valid species); Thomas, 1906a:302 (listed as valid species, including degeni Thomas, 1902a as full synonym); Dollman, 1915:169 (listed as valid species, including degeni Thomas, 1902a as full synonym); Misonne, 1974:33 (listed as valid species, allocation of synonyms without indication of rank); Yalden et al., 1976:56 (faunal work, listed as valid species, allocation of synonyms without indication of rank); Corbet \& Hill, 1980:159, 1986:178, 1991:167 (listed as valid species, no indication of synonyms); Honacki et al., 1982:445 (listed as valid species, no indication of synonyms); Musser \& Carleton, 1993:682, 2005:1530 (listed as valid species, allocation of synonyms without indication of rank); Yalden et al., 1996:119 (faunal work, listed as valid species, no indication of synonyms).

Otomys typus typus; Allen, 1939:348 (listed as valid subspecies, including degeni Thomas, 1902a as full synonym); Ellerman, 1941:321 (listed as valid subspecies, including degeni Thomas, 1902a as full synonym); Bohmann, 1952:44 (taxonomic revision, arranged as valid subspecies, including degeni Thomas, 1902a as full synonym).

Otomys irroratus [typus]; Delany, 1975:53 (faunal work, new name combination, listed in synonymy without indication of rank); Petter, 1982:219 (allocated to synonymy without indication of rank).

Distribution. Simien Mts, Ethiopia extending eastwards to the highlands of the western rim of the Ethiopian Rift.

Specimens examined. ETHIOPIA: Ankober (SM 23838); Bonke (SM 23349, 23351); Chenca (SM 2332023322, 23325, 23326, 23328, 23333-23335, 23337); Gojam (FMNH 28141-28143, 28172-28177, 28179); Gojam, N'jabara (USNM 259507); Mount Guna (ZMMU 172728-172732); Hirna (SM 23842, 23844); Simien Mountains, 10,000 ft (3048 m) (FMNH 28146-28151, 28153-28158; MCZ 34372; SM 1051); Simien Mountains, Debark, 9,200 ft (2804 m) (MCZ 34373); Simien Mountains, Mount Geech, 11,200 ft (3414 m) (MCZ 26992; FMNH 28147, 28154); Shou (FMNH 28140); Sidamo, (FMNH 28167).

\section{Otomys uzungwensis Lawrence and Loveridge, 1953}

Otomys percivali; Allen \& Loveridge, 1933:119 (faunal report, preliminary identification); Swynnerton and Hayman, 1951:322 (faunal work, listed as species per Allen \& Loveridge, 1933).

Otomys uzungwensis; Lawrence \& Loveridge, 1953:61 (type locality—Tanganyika Territory [Tanzania], Iringa District, Uzungwe Mountains, Dabaga; holotype-MCZ 26645); Musser \& Carleton, 2005:1530 (reinstated as valid species); Carleton \& Byrne, 2006:492 (taxonomic revision, retained as valid species).

Otomys typus [uzungwensis]; Misonne, 1974:33 (new name combination, listed in synonymy without indication of rank); Musser \& Carleton, 1993:682 (listed in synonymy without indication of rank).

Otomys typus uzungwensis; Ansell, 1978:78 (faunal work, listed as valid subspecies); Ansell \& Dowsett, $1988: 102$ (faunal work, listed as valid subspecies).

Distribution. Udzungwa Mountains in westcentral Tanzania to the Nyika Plateau, northern Malawi and contiguous Zambia; elevational range ca. 1800-2750 m. 

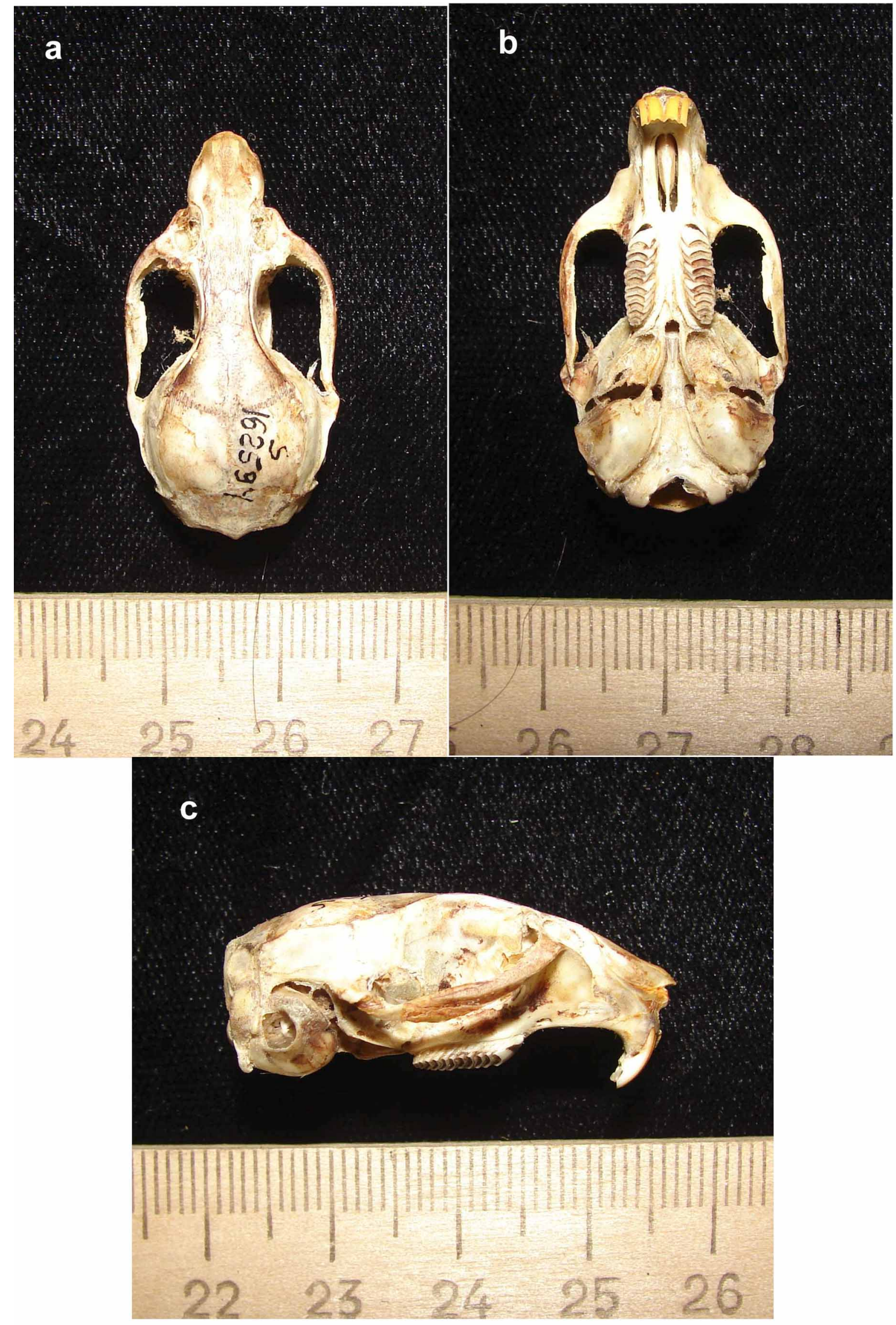

FIGURE 17(a-c). Photographs comparing dorsal, ventral and lateral views of the skulls of holotype of Otomys yaldeni (ZMMU 162594). 

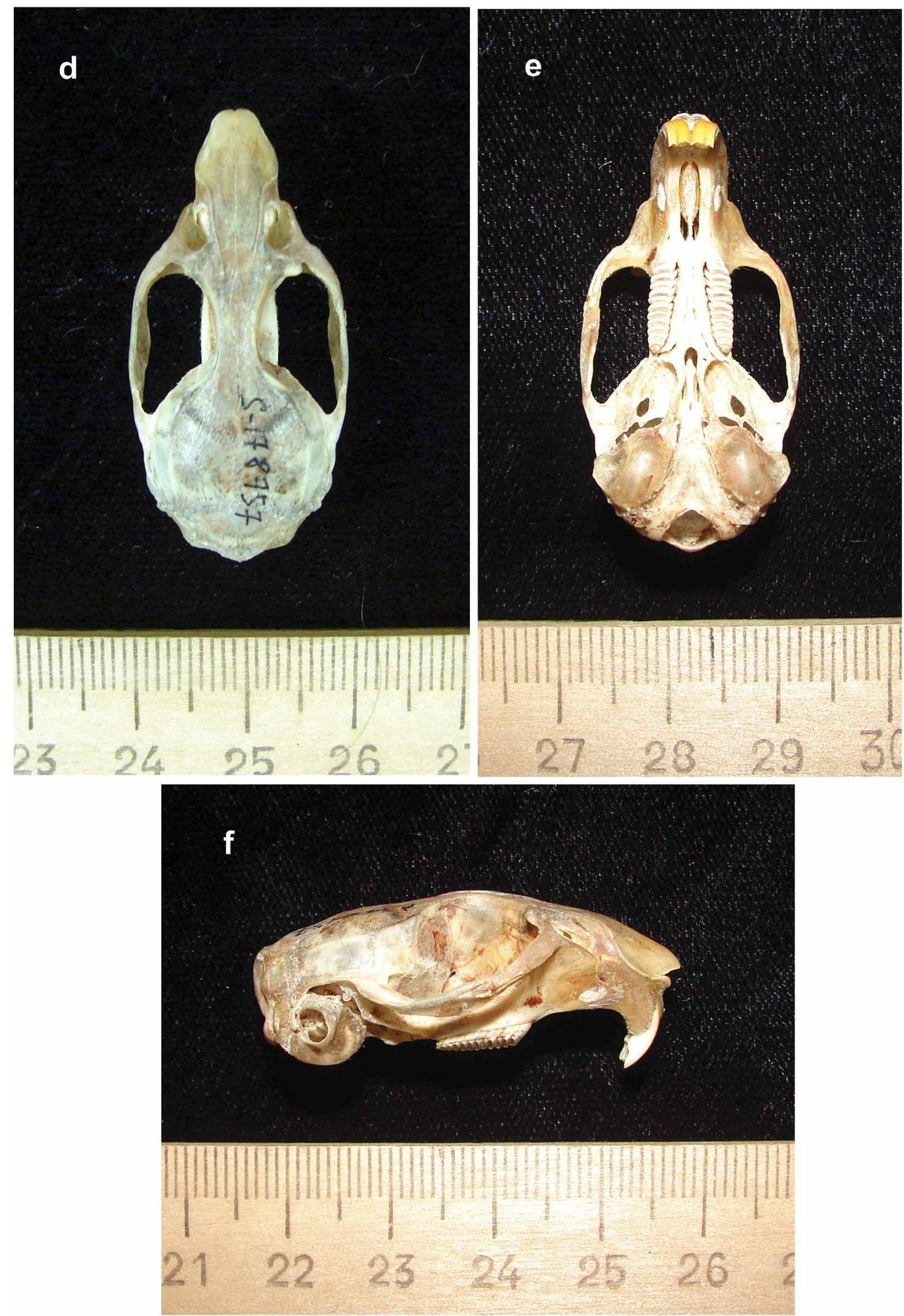

FIGURE 17(d-f). Photographs comparing dorsal, ventral and lateral views of the skulls of holotype of O. simiensis (ZMMU 178757). 

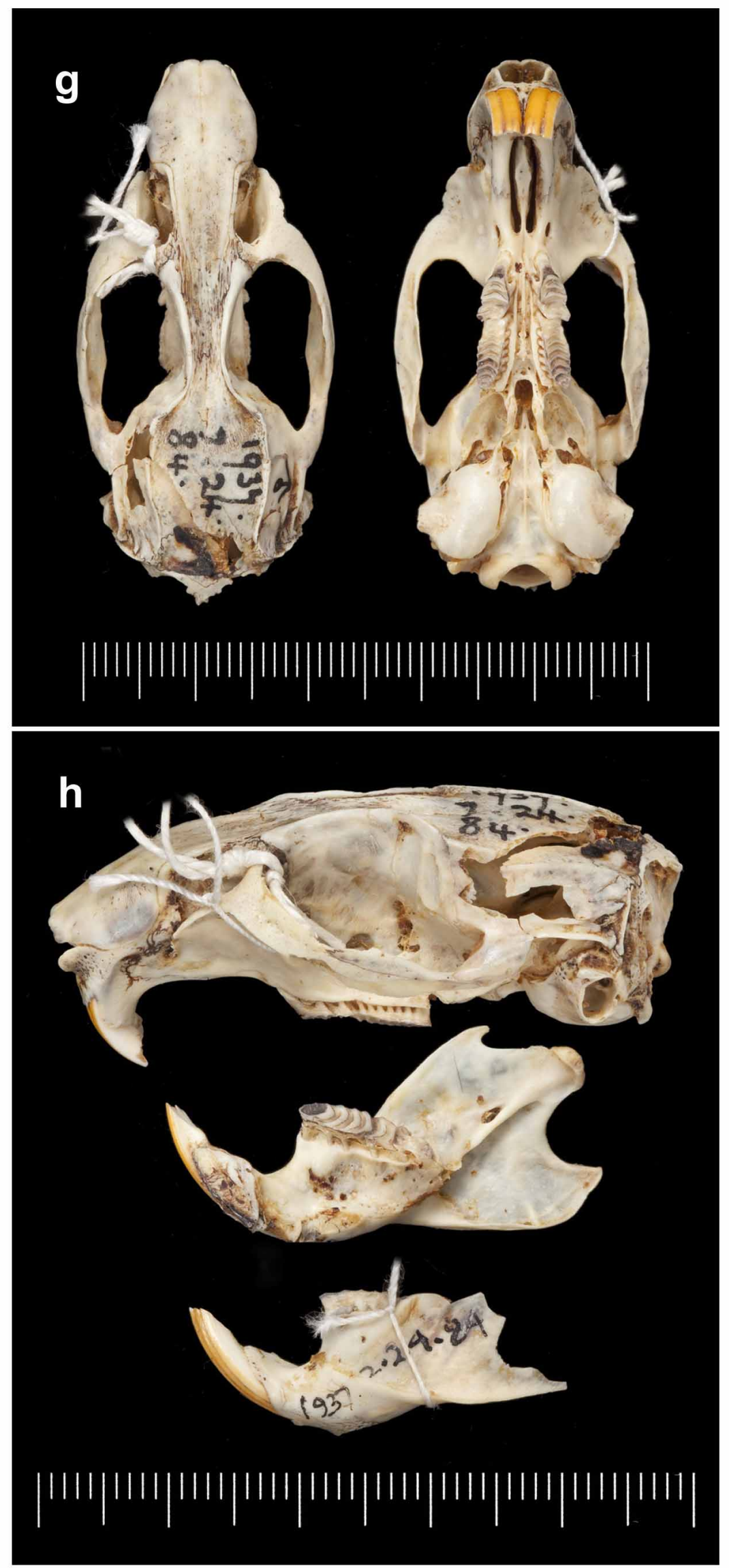

FIGURE 17(g-h). Photographs comparing dorsal, ventral and lateral views of the skulls of holotype of Otomys cheesmani (BMNH 1937.2.24.84). (O) The Natural History Museum, London. 
Specimens examined. MALAWI: Nyika Plateau, Chelinda (BMNH 62.337, 66.1094, 78.2722); Nyika Plateau, 7,000 ft (2133.6 m) (MCZ 43947, 43950); (FMNH 192029, 192030). TANZANIA: Udzungwe Mountains, Kigoro (MCZ 26637, 26638, 26640-26644); Udzungwe Mountains, Iringa District, Dabaga, 6,000 ft (1828.8 m) (MCZ 26645, 26646, 26648-26653, 26655, 26656, 26664); Poroto Mountains, Mbeya, 9,000ft (2743.2 m) (MCZ 51147).

\section{Otomys yaldeni new species}

Figs. 2b, 5, 6, 17; Table 9

Yalden's Vei Rat

Otomys sp. A: Lavrenchenko et al. 1997: 222.

Otomys typus A: Aniskin et al. 1998: 230.

Holotype. ZMMU 162594; adult male, dry skin and skull, collector's number 132; collected by L.A. Lavrenchenko, 17 February 1995.

Type locality. Ethiopia, Bale Mountains, vicinity of Dinsho, $3170 \mathrm{~m} ; 07^{\circ} 06^{\prime} \mathrm{N}, 39^{\circ} 47^{\prime} \mathrm{E}$ (interpolated from topographic map).

Diagnosis. The smallest representative of the Otomys typus complex (excluding O. jacksoni on Mt Elgon). Similar to $O$. simiensis, but considerably smaller in external and craniodental size, possessing a wider interorbital region, more pronounced supraorbital ridges, relatively smaller rostral region (clearly shortened nasal bones), more rounded and deeper braincase (Fig. 17), and distinct karyotype $(2 \mathrm{~N}=56, \mathrm{NF}=56, \mathrm{NFa}=54)$.

Paratypes. BMNH 76.114 (Ethiopia, 70 km NW Kebre Mengist, 2650 m; 06²3'N, 38³5'E; adult male, dry skin and skull, collector's number 121; collected by D.W. Yalden, P.A. Morris \& M.J. Largen, 13 April 1975); BMNH 76.115 (Ethiopia, Bale Mountains, $17 \mathrm{~km}$ SE of Goba, $3800 \mathrm{~m} ; 06^{\circ} 53^{\prime} \mathrm{N}, 40^{\circ} 03^{\prime} \mathrm{E}$; adult female, dry skin and skull, collector's number 201; collected by D.W. Yalden, P.A. Morris \& M.J. Largen, 19 April 1975); BMNH 76.116 (Ethiopia, Bale Mountains, $10 \mathrm{~km}$ SE of Goba, $3300 \mathrm{~m}$; 06 $57^{\prime} \mathrm{N}, 40^{\circ} 03^{\prime} \mathrm{E}$; adult female, dry skin and skull, collector's number 175; collected by D.W. Yalden, P.A. Morris \& M.J. Largen, 18 April 1975).

Description. A small-sized Otomys with a relatively short tail. The dorsal pelage is drab brown, the hairs are greyish at base and yellow-rufous in distal part. Among the guard hairs (11-12 mm), there are longer bristles (20 mm) that produce the effect of double-layered fur. Ventral pelage is pale grey, individual hairs grey at the base and tipped with pale whitish. The ears are blackish, their inner surface covered with short rufous hairs. The dorsal surface of the forefeet and hind feet is dark grey; the claws are grey. The tail is relatively short ( $49.9 \%$ of HB), with blackish caudal hairs on the upper surface and nearly white hairs on the lower; however, given its shortness, the bicoloration of the tail does not appear as well defined as in $O$. simiensis.

The small skull features a relatively wide interorbital region, markedly well-developed supraorbital ridges, very small rostral region with narrow nasals, short anterior palatal foramen, and small tympanic bullae (Fig. 17; Table 9). Anterior face of the lower incisor is scored by two well defined and equally deep grooves. The upper third molar possesses 6 or 7 complete laminae; the lower first molar possesses 4 complete laminae.

Otomys yaldeni averages smaller than all other species formerly obscured under $O$. typus except for O. jacksoni (Table 9). However it can be easily distinguished from $O$. jacksoni on the basis of skull shape. Compared with $O$. yaldeni, the holotype of $O$. jacksoni displays a much narrower interorbital region, with weakly developed supraorbital ridges, and does not possess such conspicuously shortened nasal bones (Fig. 17). Otomys yaldeni differs from other Ethiopian Otomys (excluding O. simiensis) by the lower number of laminae in the upper third molar (6-7 vs. 8-9) and by its double-layered dorsal fur.

The chromosomal set of $O$. yaldeni consists of $2 n=56, \mathrm{NF}=56, \mathrm{NFa}=54$, acrocentrics with an acrocentric $\mathrm{X}$ and Y (Fig. 2b). Allozymic investigation of 18 enzymatic and non-enzymatic proteins (Adh, Alb, Gdc, Hbb, Got-1, Got-2, G-6-pd, Dia-1, Dia-2, Idh-1, Ldh-A, Ldh-B, Mdh-1, Mdh-2, Me-1, Sdh, Sod-1, Sod-2) revealed that non-overlapping allele spectra in four loci (G-6-pd, Dia-2, Alb and Got-2) discriminated $O$. yaldeni and $O$. helleri, which are partially sympatric in the Bale Mountains (Lavrenchenko et al. 1997).

Distribution. Documented from the northern (Dinsho and Goba areas) and south-western (70 km NW Kebre Mengist) slopes of the Bale Massif, southeastern Ethiopia.

Ecology. All known specimens of $O$. yaldeni were collected in mosaic habitats of grassland and forest between 2650 and $3800 \mathrm{~m}$. The holotype was captured at the edge of typical undifferentiated afromontane forest with Junipe- 
rus procera, Hypericum revolutum, Maytenus arbutifolia, Rosa abyssinica and open grassy patches with Euphorbia dumalis, Festuca abyssinica, Koeleria capensis, Poa schimperana, Exotheca abyssinica. The paratypes were captured in afromontane forest with Hagenia abyssinica and bamboo patches with Arundinaria alpine (BMNH 76.114), in moorland with Erica trimera and Helichrysum citrispinum (BMNH 76.115), in open woodland with Hypericum revolutum and Helichrysum citrispinum (BMNH 76.116).

Etymology. The species name acknowledges the substantial contributions of Derek W. Yalden to our understanding of Ethiopia's indigenous mammals. His museum and field efforts, published over some 20 years in faunal reports and taxonomic catalogues (e.g., Yalden et al. 1976, 1996), meaningfully advanced specimen-based knowledge of species and their distributions, thereby underscoring the exceptional endemism that characterizes the mammal fauna of the Ethiopian highlands. Otomys yaldeni appropriately represents another of those endemics. The species name combines the surname Yalden and genitive singular case-ending " $i$ ” indicative of masculine gender.

\section{Otomys zinki Bohmann, 1943}

Otomys typus zinki; Bohmann, 1943:153 (type locality—German East Africa [Tanzania], Kilimanjaro, Peters Hut, 3800 m; holotype — not seen; listed as "No. 548" in his private collection by Bohmann, 1943); Swynnerton and Hayman, 1951:321 (faunal report, listed as valid subspecies); Bohmann, 1952:41 (taxonomic revision, retained as valid subspecies).

Otomys typus [zinki]; Misonne, 1974:33 (listed in synonymy without indication of rank); Musser \& Carleton, 1993:682 (listed in synonymy without indication of rank).

Otomys orestes [zinki]; Musser \& Carleton, 2005:1528 (new name combination, listed in synonymy without indication of rank).

Distribution. The species is limited in its distribution to Mt Kilimanjaro.

Specimens examined. TANZANIA: Kilimanjaro (SM 4270, 4272, 4278, 4280); Mount Kilimanjaro East, Maundi Crater, grassland, 3270 m (RMCA 96.037.M-6801, 96.037.M-6802, 96.037.M-6803, 96.037.M-6804, 96.037.M-6805, 96.037.M-6801); Mount Kilimanjaro West, Londorosi, forest, $2350 \mathrm{~m}$ (96.037.M-6807, 96.037.M-6810); Mount Kilimanjaro West, Shira, moorland, 3000 m (96.037.M-6809); Mount Kilimanjaro, Kilimanjaro National Park, 13,100 ft (3993 m) (FMNH 174178-174180); Mount Kilimanjaro, Kilimanjaro National Park, $7 \mathrm{~km} \mathrm{~N}$ and $2.5 \mathrm{~km}$ W Maua, 8,100 ft (2469 m) (FMNH 174173, 174174).

TABLE 9. Summary statistics for taxa recognised by this study.

\begin{tabular}{|c|c|c|c|c|}
\hline Species & $\mathrm{N}$ & Mean & Range & Standard deviation \\
\hline \multicolumn{5}{|l|}{ Head and Body Length } \\
\hline O. tropicalis s.s & 37 & 159.0 & $125-205$ & 17.6 \\
\hline O. typus s.s. & 4 & 163.2 & $155-178$ & 10.1 \\
\hline O. fortior & 8 & 160.2 & $145-182$ & 13.4 \\
\hline O. yaldeni sp. nov. (= "Sp. A") & 3 & 143.3 & $125-155$ & 16.1 \\
\hline O. helleri (= “Sp. B") & 12 & 151.6 & $123-185$ & 20.9 \\
\hline O. cheesmani sp. nov. (= “Sp. C”) & 6 & 188.8 & $165-210$ & 17.5 \\
\hline O. simiensis sp. nov. (= “Sp. D”) & 5 & 155.2 & $135-172$ & 15.0 \\
\hline O. zinki & 16 & 161.6 & $135-186$ & 13.7 \\
\hline O. orestes & 9 & 156.7 & $135-172$ & 11.0 \\
\hline O. thomasi & 3 & 170.7 & $162-182$ & 10.3 \\
\hline O. dartmouthi & 1 & - & 150 & - \\
\hline O. uzungwensis & - & - & - & - \\
\hline O. jacksoni & 1 & - & 141 & - \\
\hline \multicolumn{5}{|l|}{ Length of Tail } \\
\hline O. tropicalis s.s. & 37 & 86.7 & $52-102$ & 9.5 \\
\hline
\end{tabular}


TABLE 9. (continued)

\begin{tabular}{lllll}
\hline Species & $\mathrm{N}$ & Mean & Range & Standard deviation \\
\hline O. typus s.s. & 4 & 83.7 & $77-92$ & 7.6 \\
O. fortior & 8 & 93.7 & $85-98$ & 4.0 \\
O. yaldeni sp. nov. (= "Sp. A") & 3 & 71.5 & $70-73$ & 2.1 \\
O. helleri (= "Sp. B") & 12 & 80.8 & $68-95$ & 8.4 \\
O. cheesmani sp. nov. (= "Sp. C") & 6 & 93.0 & $77-106$ & 9.6 \\
O. simiensis sp. nov. (= "Sp. D") & 5 & 82.8 & $77-88$ & 4.3 \\
O. zinki & 15 & 84.1 & $60-108$ & 12.1 \\
O. orestes & 9 & 79.8 & $69-93$ & 6.9 \\
O. thomasi & 3 & 88.3 & $84-93$ & 4.5 \\
O. dartmouthi & 1 & - & 93 & - \\
O. uzungwensis & - & - & - & - \\
O. jacksoni & 1 & - & 64 & -
\end{tabular}

Length of Hind Foot

O. t. tropicalis s.s.

O. typus s.s.

26.0

25-27

0.8

O. fortior

28.8

28-30

0.9

O. yaldeni sp. nov. (= "Sp. A")

23.7

22-25

1.5

O. helleri (= "Sp. B")

23-30

O. cheesmani sp. nov. (= "Sp. C")

27.0

28-31

1.3

O. simiensis $\mathbf{s p . ~ n o v . ~ ( = ~ " S p . ~ D ” ) ~}$

30.2

24-26

0.6

O. zinki

25.0

24-32

2.1

O. orestes

27.1

23-31

2.6

O. thomasi

30.3

30-31

0.6

O. dartmouthi

O. uzungwensis

O. jacksoni

26.5

21

Length of Ear

O. t. tropicalis s.s.

21.9

17-25

1.9

O. typus s.s.

21.8

20-25

2.2

O. fortior

21.3

20-26

2.0

O. yaldeni sp. nov. (= "Sp. A")

19.2

18.5-20

1.1

O. helleri (= "Sp. B")

21.8

20-24.5

1.4

O. cheesmani sp. nov. (= "Sp. C")

23.2

22-24

0.8

O. simiensis sp. nov. (= "Sp. D”)

19.4

$17.5-21.8$

1.6

O. zinki

O. orestes

22.0

21-25

1.7

O. thomasi

21.3

20-22

1.2

O. dartmouthi

O. uzungwensis

O. jacksoni 
TABLE 9. (continued)

\begin{tabular}{|c|c|c|c|c|}
\hline Species & $\mathrm{N}$ & Mean & Range & Standard deviation \\
\hline \multicolumn{5}{|l|}{ Occipitonasal Length } \\
\hline O. tropicalis s.s. & 124 & 39.6 & $35.8-44.0$ & 1.9 \\
\hline O. typus s.s. & 4 & 38.3 & $37.1-40.2$ & 1.4 \\
\hline O. fortior & 8 & 39.6 & $36.6-42.6$ & 2.4 \\
\hline O. yaldeni sp. nov. (= "Sp. A") & 3 & 35.2 & $34.7-35.5$ & 0.4 \\
\hline O. helleri (= "Sp. B”) & 12 & 38.7 & $34.6-43.3$ & 3.0 \\
\hline O. cheesmani sp. nov. (= “Sp. C") & 6 & 45.3 & $43.3-48.2$ & 1.8 \\
\hline O. simiensis sp. nov. (= “Sp. D”) & 5 & 37.0 & $35.2-39.2$ & 1.7 \\
\hline O. zinki & 12 & 39.4 & $36.6-42.4$ & 1.7 \\
\hline O. orestes & 14 & 38.4 & $37.3-39.5$ & 0.8 \\
\hline O. thomasi & 5 & 40.8 & $40.2-41.4$ & 0.6 \\
\hline O. dartmouthi & 9 & 37.8 & $36.6-39.1$ & 0.7 \\
\hline O. uzungwensis & 10 & 37.3 & $36.0-38.9$ & 1.0 \\
\hline O. jacksoni & 3 & 35.1 & $34.3-35.5$ & 0.7 \\
\hline \multicolumn{5}{|l|}{ Depth of Braincase } \\
\hline O. tropicalis s.s. & 124 & 11.4 & $10.2-12.9$ & 0.6 \\
\hline O. typus s.s. & 4 & 10.9 & $10.5-11.1$ & 0.2 \\
\hline O. fortior & 8 & 10.8 & $10.0-11.3$ & 0.5 \\
\hline O. yaldeni sp. nov. (= "Sp. A") & 3 & 10.5 & $9.9-10.7$ & 0.4 \\
\hline O. helleri (= "Sp. B") & 12 & 11.2 & $10.3-11.8$ & 0.5 \\
\hline O. cheesmani sp. nov. (= "Sp. C") & 6 & 12.0 & $11.3-13.1$ & 0.6 \\
\hline O. simiensis sp. nov. (= “Sp. D”) & 5 & 10.1 & $9.6-10.6$ & 0.4 \\
\hline O. zinki & 12 & 11.5 & $10.9-12.5$ & 0.6 \\
\hline O. orestes & 14 & 11.8 & $10.6-12.6$ & 0.5 \\
\hline O. thomasi & 5 & 11.5 & $10.6-12.9$ & 0.9 \\
\hline O. dartmouthi & 9 & 11.0 & $10.6-11.5$ & 0.3 \\
\hline O. uzungwensis & 10 & 11.2 & $10.5-11.6$ & 0.3 \\
\hline O. jacksoni & 3 & 11.0 & $10.8-11.2$ & 0.2 \\
\hline \multicolumn{5}{|l|}{ Length of Anterior Palatal Foramen } \\
\hline O. tropicalis s.s. & 124 & 7.0 & $5.9-9.2$ & 0.5 \\
\hline O. typus s.s. & 4 & 6.7 & $5.9-7.3$ & 0.6 \\
\hline O. fortior & 8 & 7.2 & $6.5-7.8$ & 0.4 \\
\hline O. yaldeni sp. nov. (= "Sp. A") & 3 & 6.0 & $5.6-6.5$ & 0.4 \\
\hline O. helleri (= "Sp. B") & 12 & 6.7 & $5.6-7.5$ & 0.7 \\
\hline O. cheesmani sp. nov. (= "Sp. C") & 6 & 8.2 & $7.5-8.9$ & 0.6 \\
\hline O. simiensis sp. nov. (= "Sp. D”) & 5 & 6.2 & $5.6-6.6$ & 0.4 \\
\hline O. zinki & 12 & 7.3 & $6.7-8.2$ & 0.5 \\
\hline O. orestes & 14 & 7.2 & $6.5-7.7$ & 0.4 \\
\hline O. thomasi & 5 & 7.4 & $7.1-7.5$ & 0.2 \\
\hline
\end{tabular}


TABLE 9. (continued)

\begin{tabular}{lllll}
\hline Species & $\mathrm{N}$ & Mean & Range & Standard deviation \\
\hline O. dartmouthi & 9 & 6.9 & $6.2-7.4$ & 0.4 \\
O. uzungwensis & 10 & 6.7 & $6.2-7.2$ & 0.3 \\
O. jacksoni & 3 & 6.3 & $5.8-6.8$ & 0.5
\end{tabular}

Length of Maxillary Toothrow

$\begin{array}{lllll}\text { O. tropicalis } \text { s.s. } & 124 & 9.3 & 8.2-10.4 & 0.4 \\ \text { O. typus s.s. } & 4 & 9.8 & 9.3-10.0 & 0.3 \\ \text { O. fortior } & 8 & 9.8 & 9.2-10.3 & 0.5 \\ \text { O. yaldeni sp. nov. (= "Sp. A") } & 3 & 8.4 & 8.1-8.6 & 0.3 \\ \text { O. helleri (= "Sp. B") } & 12 & 9.6 & 9.0-10.5 & 0.4 \\ \text { O. cheesmani sp. nov. (= "Sp. C") } & 6 & 11.4 & 11.0-12.0 & 0.3 \\ \text { O. simiensis sp. nov. (= "Sp. D") } & 5 & 8.8 & 8.6-8.9 & 0.1 \\ \text { O. zinki } & 12 & 9.2 & 8.3-10.0 & 0.4 \\ \text { O. } \text { orestes } & 14 & 9.3 & 8.8-9.8 & 0.3 \\ \text { O. thomasi } & 5 & 9.4 & 9.2-9.7 & 0.2 \\ \text { O. dartmouthi } & 9 & 8.8 & 8.1-9.4 & 0.4 \\ \text { O. uzungwensis } & 10 & 9.1 & 8.6-9.5 & 0.3 \\ \text { O. jacksoni } & 3 & 8.4 & 8.2-8.5 & 0.2\end{array}$

Greatest Width Across Nasals

O. tropicalis s.s.

$124 \quad 7.2$

6.4-8.6 $\quad 0.4$

O. typus s.s.

$4 \quad 7.0$

$6.5-7.5$

0.4

O. fortior

$8 \quad 7.3$

$6.8-8.0$

0.5

O. yaldeni sp. nov. (= "Sp. A")

3

6.2

$6.1-6.2$

0.1

O. helleri (= "Sp. B")

$5.8-7.0$

0.4

O. cheesmani sp. nov. (= "Sp. C")

8.0-9.7

0.7

O. simiensis sp. nov. (= "Sp. D")

8.8

$6.3-6.9$

0.3

O. zinki

7.1

$6.4-7.5$

0.3

O. orestes

6.9

$6.3-7.4$

0.4

O. thomasi

7.2

6.8-7.6

0.3

O. dartmouthi

6.8

O. uzungwensis

$6.5-7.1$

0.2

O. jacksoni

7.2

$6.9-7.5$

0.2

3

6.4

$6.2-6.8$

0.3

Interorbital Constriction

O. tropicalis s.s.

$3.7-5.0$

0.2

O. typus s.s.

$3.6-4.0$

0.2

O. fortior

4.1

$3.8-4.5$

0.2

O. yaldeni sp. nov. (= "Sp. A")

4.0

$3.6-4.5$

0.4

O. helleri (= Sp. B)

$3.4-4.1$

0.2

O. cheesmani sp. nov. (= "Sp. C")

$12 \quad 3.8$

$3.8-4.4$

0.2

O. simiensis (= "Sp. D")

4.0

$3.3-4.1$

0.3

O. zinki

$5 \quad 3.6$

3.8-4.5 
TABLE 9. (continued)

\begin{tabular}{lllll}
\hline Species & $\mathrm{N}$ & Mean & Range & Standard deviation \\
\hline O. orestes & 14 & 4.1 & $3.7-4.7$ & 0.3 \\
O. thomasi & 5 & 4.1 & $4.0-4.4$ & 0.2 \\
O. dartmouthi & 9 & 4.2 & $3.9-4.4$ & 0.2 \\
O. uzungwensis & 10 & 4.0 & $3.9-4.2$ & 0.1 \\
O. jacksoni & 3 & 3.8 & $3.7-3.8$ & 0.1
\end{tabular}

Zygomatic Width

O. tropicalis s.s.

19.3

$17.3-21.8$

0.9

O. typus s.s.

$4 \quad 18.9$

18.4-19.7

0.6

O. fortior

18.2-20.7

1.0

O. yaldeni sp. nov. (= "Sp. A")

17.6

$17.4-17.8$

0.2

O. helleri (= "Sp. B")

$12 \quad 19.0$

$17.4-21.0$

1.2

O. cheesmani sp. nov. (= "Sp. C")

$6 \quad 21.5$

$20.5-22.8$

0.8

O. simiensis sp. nov. (= "Sp. D”)

5

18.4

$17.6-19.3$

0.7

O. zinki

12

19.2

$17.6-21.1$

1.0

O. orestes

19.6

$19.0-20.7$

0.5

O. thomasi

20.8

19.7-21.5

0.8

O. dartmouthi

19.2

18.3-19.7

0.5

O. uzungwensis

18.2

16.9-19.2

0.8

O. jacksoni

17.5

17.5-17.6

0.1

Palatal Length

O. tropicalis s.s.

124

O. typus s.s.

4

O. fortiori

$8 \quad 21.6$

21.5

18.6-24.6

1.2

O. yaldeni sp. nov. (= "Sp. A")

19.2

20.2-21.9

0.7

O. helleri (= Sp. B)

3

19.9-23.2

1.3

18.9-19.3

0.2

$12 \quad 21.1$

18.8-23.6

1.6

O. cheesmani sp. nov. (= "Sp. C")

$\begin{array}{ll}6 & 24.8\end{array}$

23.6-26.2

0.9

O. simiensissp. nov. (= "Sp. D”)

20.2

19.2-21.3

0.9

O. zinki

21.2

19.3-22.8

1.0

O. orestes

20.3

16.7-21.7

1.2

O. thomasi

22.2

21.4-22.7

0.6

O. dartmouthi

20.2

19.6-21.5

0.6

O. uzungwensis

$10 \quad 20.4$

19.8-21.7

0.7

O. jacksoni

18.2

$17.4-19.2$

0.9

Length of Auditory Bulla

O. tropicalis s.s.

$\begin{array}{ll}124 & 7.5 \\ 4 & 7.4 \\ 8 & 7.8 \\ 3 & 6.5 \\ 12 & 7.9 \\ 6 & 8.4\end{array}$

6.4-9.1

0.4

O. typus s.s.

$6.8-7.7$

0.4

O. fortior

$7.4-8.2$

0.3

O. yaldeni sp. nov. (= "Sp. A")

6.5

6.3-6.8

0.3

O. helleri (= "Sp. B")

$7.2-9.2$

0.6

O. cheesmani sp. nov. (= "Sp. C")

8.4

7.6-8.8

0.4 
TABLE 9. (continued)

\begin{tabular}{lllll}
\hline Species & $\mathrm{N}$ & Mean & Range & Standard deviation \\
\hline O. simiensis sp. nov. (= "Sp. D”) & 5 & 7.0 & $6.6-7.2$ & 0.2 \\
O. zinki & 12 & 8.0 & $7.2-8.9$ & 0.6 \\
O. orestes & 14 & 7.9 & $7.4-8.5$ & 0.3 \\
O. thomasi & 5 & 8.3 & $7.7-8.7$ & 0.4 \\
O. dartmouthi & 9 & 7.01 & $6.7-7.6$ & 0.3 \\
O. uzungwensis & 10 & 7.2 & $6.7-7.5$ & 0.2 \\
O. jacksoni & 3 & 7.0 & $6.8-7.0$ & 0.1 \\
\hline
\end{tabular}

\section{Acknowledgements}

We are indebted to the many curators who facilitated access to museum collections of Otomys: John Phelps, William T. Stanley, and Lawrence Heaney from the Field Museum of Natural History (FMNH); Farish Jenkins and Judith Chapasko from the Museum of Comparative Zoology, Harvard (MCZ); Wim Van Neer and Wim Wendelin from the Royal Museum for Central Africa, Tervuren, Belgium (RMCA); Linda Gordon and Michael Carleton from the Smithsonian Museum of Natural History, Washington DC (USNM); Fritz Dieterlen from the Museum für Naturkunde, Stuttgart, Germany (SM); Paula Jenkins from the Natural History Museum, London (BM); and Teresa Kearney from the Transvaal Museum, Northern Flagship Institute, Pretoria (TM). We are grateful to Paulina Jenkins and additional staff of the Natural History Museum, London for arranging and granting permission for the use of high quality photographs of the holotype of Otomys cheesmani sp. nov. Vladimir M. Aniskin and Nina Sh. Bulatova (Severtsov Institute of Ecology and Evolution, RAS) made an inestimable contribution to the karyological part of this study. We gratefully acknowledge the financial assistance of the Smithsonian Institution Short Term Visitor Award (in 2006), and a South African National Research Foundation Grant (between 2005 and 2007), which allowed P.J.T. to visit and study important North American and European museum collections of Otomys. We thank Julian Kerbis, Christiane Denys, Ann Laudisoit and L. J. McLellan for donating tissues for molecular analysis. We are grateful to two anonymous reviewers whose comments immeasurably improved this paper.

\section{References}

Abdel-Rahman, E.H., Taylor, P.J., Contrafatto, G., Lamb, J.M., Bloomer, P. \& Chimimba, C.T. (2009) Geometric craniometric analysis of sexual dimorphism and ontogenetic variation: A case study based on two geographically disparate species, Aethomys ineptus from southern Africa and Arvicanthis niloticus from Sudan (Rodentia: Muridae). Mammalian Biology, $74,361-373$.

Addinsoft (2007) XLSTAT ver. 2007.5. [Computer software]. Addinsoft, France.

Allard, M.W. \& Honeycutt, R.L. (1992) Nucleotide sequence variation in the mitochondrial 12S rRNA gene and the phylogeny of the African mole-rats (Rodentia: Bathyergidae). Molecular Biology \& Evolution, 9, 27-40.

Allen, G.M. (1939) A checklist of African mammals. Bulletin of the Museum of Comparative Zoology at Harvard College, 83, $1-763$.

Allen, G.M. \& Loveridge, A. (1933) Reports on the scientific results of an expedition to the southwestern highlands of Tanganyika Territory. II. Mammals. Bulletin of the Museum of Comparative Zoology at Harvard College, 75, 47-140.

Aniskin, V.M., Lavrenchenko, L.A., Milishnikov, A.N. \& Warshavsky, A.A. (1998) Karyotypes of small mammals (Insectivora, Rodentia) of the Bale Mountains, Ethiopia. In: Sokolov, V.E., Rozhnov, V.V., Serbenyuk, M.A. (Eds.), Behaviour, communication and ecology of mammals. Inst. Ecol. Evol. RAS, Moscow, pp. 217-236.

Ansell, W.F.H. (1978) The mammals of Zambia. Chilanga, Zambia, The National Parks and Wildlife Service, 126 pp.

Ansell, W.F.H. \& Dowsett, R.J. (1988) Mammals of Malawi: An annotated checklist and atlas. Cornwall, The Trendrine Press, $170 \mathrm{pp}$.

Avise, J.C. (2000) Phylogeography. The history and formation of species. Harvard University Press, Cambridge, Massachusetts.

Bohmann, L. (1943) Zwei neue Otomys-Rassen aus Ostafrika. Zoologischer Anzeiger, 143, 153-155.

Bohmann, L. (1952) Die afrikanische Nagergattung Otomys F. Cuvier. Zeitschrift für Säugetierkunde, 18, 1-80.

Bond, Jason E. \& Stockman, Amy K.(2008) An integrative method for delimiting cohesion species: finding the population-spe- 
cies interface in a group of Californian trapdoor spiders with extreme genetic divergence and geographic structuring, Systematic Biology, 57, 628-646.

Bowie, C.K., Fjeldså, J, Hackett, S.J. \& Crowe, T.M. (2004) Molecular evolution in space and through time: mtDNA phylogeography of the Olive Sunbird (Nectarinia olivacea/obscura) throughout continental Africa. Molecular Phylogenetics and Evolution, 33, 56-74.

Bowie, C.K., Fjeldså, J., Hackett, S.J., Bates, J.M. \& Crowe, T.M. (2006) Coalescent models reveal the relative roles of ancestral polymorphism, vicariance, and dispersal in shaping phylogeographical structure of an African montane forest robin. Molecular Phylogenetics and Evolution, 38, 171-188.

Carleton, M.D. \& Byrne, E.S. (2006) The status of Otomys orestes dollmani Heller, 1912 (Muridae: Otomyinae), a rodent described from the Mathews Range, central Kenya. Proceedings of the Biological Society of Washington, 119, 477-515.

Carleton, M.D. \& Musser, G.G. (1984) Muroid Rodents. In: Anderson, S. \& Jones, J.K. (Eds.), Orders and Families of Recent Mammals of the World. Wiley Press, New York, pp. 289-379.

Carleton, M.D. \& Stanley, W.T. (2005) Review of the Hylomyscus denniae complex (Rodentia: Muridae) in Tanzania, with description of a new species. Proceedings of the Biological Society of Washington, 118, 619-646.

Carleton, M.D., Kerbis Peterhans, J.C. \& Stanley, W.T. (2006) Review of the Hylomyscus denniae group (Rodentia: Muridae) in eastern Africa, with comments on the generic allocation of Epimys endorobae Heller. Proceedings of the Biological Society of Washington, 119, 293-325.

Corbet, G.B. \& Hill, J.E. (1980) A world list of mammalian species. British Museum (Natural History), London. 226 pp.

Corbet, G.B. \& Hill, J.E. (1986) A world list of mammalian species, 2nd edition. British Museum (Natural History) Publications, London. $254 \mathrm{pp}$.

Corbet, G.B. \& Hill, J.E. (1991) A world list of mammalian species, 3rd edition. British Museum (Natural History) Publications, London. 243 pp.

Corti. M. (1993) Geometric morphometrics: an extension of the revolution. Trends in Ecology and Evolution, 8, 302-303.

Delany, M.J. (1975) The rodents of Uganda. London, Trustees of the British Museum (Natural History), 165 pp.

de Menocal, P.B. (1995) Plio-Pleistocene African climate. Science, 270, 53-59.

de Menocal, P.B. (2004) African climate change and faunal evolution during the Pliocene-Pleistocene. Earth and Planetary Science Letters, 220, 3-24.

Denys, C. (1989) Phylogenetic affinities of the oldest East African Otomys (Rodentia, Mammalia) from Olduvai Bed I (Pleistocene, Tanzania). Neues Jahrbuch für Geologie und Paläontologie Monatshefte, 12, 705-725.

Denys, C. (1999) Of mice and men. Evolution in East and South Africa during Plio-Pleistocene times. In: Bromage, T.G. \& Schrenk, F. (Eds.), African biogeography, climate change and human evolution. Oxford University Press, New York \& Oxford, pp. 226-252.

Denys, C. (2003) Evolution du genre Otomys (Rodentia: Muridae) au Plio-Pléistocène d'Afrique orientale et australe. In: Petculescu, S. (Ed.), Advances in vertebrate palaeontology "Hen to Pantha", Papers in honour of C. Radulescu and P. M. Samson. Institute of Speleology "Emile Pacovitsa”, Bucarest, Romania, pp. 75-84.

Dieterlen, F. \& Van der Straeten, E. (1992) Species of the genus Otomys from Cameroon and Nigeria and their relationship to East African forms. Bonner Zoologische Beiträge, 43, 383-392.

Dollman, G. (1915) On the swamp-rats (Otomys) of East Africa. Annals and Magazine of Natural History, series 8 15, 149170.

Drummond, A.J. \& Rambaut, A. (2006a) BEAST v1.4. Bayesian evolutionary analysis sampling trees. Available from http:// beast.bio.ed.ac.uk (accessed 17 May 2011).

Drummond, A.J. \& Rambaut, A. (2006b) BEAUti v. 1.4. Bayesian evolutionary analysis utility. Available from http:// beast.bio.ed.ac.uk (accessed 17 May 2011).

Drummond, A.J., Ho, S.Y.W., Phillips, M.J. \& Rambaut, A. (2006) Relaxed phylogenetics and dating with confidence. PLoS Biology, 4(5), e88. doi:10.1371/journal.pbio.0040088.

Ellerman, J.R. (1941) The families and genera of living rodents. Volume II. Family Muridae. British Museum (Natural History), London. 690 pp.

Fahr, J., Vierhaus, H., Hutterer, R. \& Kock, D. (2002) A revision of the Rhinolophus maclaudi species group with the description of a new species from West Africa (Chiroptera: Rhinolophidae). Myotis, 40, 95-126.

Felsenstein, J. (1981) Evolutionary trees from DNA sequences: a maximum likelihood approach. Journal of Molecular Evolution, 17, 368-376.

Felsenstein, J. (1985) Confidence limits on phylogenies: an approach using bootstrap. Evolution, 39, 783-791.

Felsenstein, J. (1988) Phylogenies from molecular sequences: inference and reliability. Annual Review of Genetics, 22, 521565 .

Ford, C.E. \& Hamerton, J.L. (1956) A colchicine hypotonic citrate, squash sequence for mammalian chromosomes. Stain Technology, 31: 247-251.

Frick, C. (1914) A new genus and some new species of Abyssinian rodents. Annals of the Carnegie Museum, 9, 7-28.

Hatt, R.T. (1934) Fourteen hitherto unrecognized African rodents. American Museum Novitates, 708, 1-15.

Hijmans, R.J., Cameron, S.E, Parra, J.L., Jones, P.G. \& Jarvis, A. (2005) Very high resolution interpolated climate surfaces for global land areas. International Journal of Climatology, 25, 1965-1978 .

Honacki, J.H., Kinman, K.E. \& Koeppl, J.W. (Eds.) (1982) Mammal species of the world, a taxonomic and geographic refer- 
ence. Allen Press, Lawrence, Kansas. Inc. and The Association of Systematics Collections, 694 pp.

Huelsenbeck, J.P. \& Ronquist F. (2001) MrBayes: Bayesian inference of phylogenetic trees. Bioinformatics, 17(8), 754-755.

Huelsenbeck, J.P. \& Ronquist, F. (2003) MrBayes: A program for the Bayesian inference of phylogeny, version 3.1.2. Rochester, New York.

Huhndorf, M.H., Kerbis Peterhans, J.C. \& Loew, S.S. (2007) Comparative phylogeography of three endemic rodents from the Albertine Rift, east central Africa. Molecular Ecology, 16(3), 663-674.

Jacobs, L.L. \& Downs, W.R. (1994) The evolution of murine rodents in Asia. In Yukimitsu Tomida, Chuankuei Li, and Takeshi Setoguchi (Eds.), Rodent and Lagomorph Families of Asian Origins and Diversification. National Science Museum, Tokyo, Monograph Series, pp. 149-156.

Kerbis Peterhans, J.C., Kityo, R.M., Stanley, W.T. \& Austin, P.K. (1998) Small mammals along an elevational gradient in Ruwenzori Mountains National Park, Uganda. In: Osmaston, H. et al., (Eds.), The Ruwenzori Mountains National Park, Uganda. Exploration, environment \& biology. Conservation, Management and Community Relations. Makerere University, Kampala, Uganda, pp.149-171.

Kluge, A.G. \& Farris, J.S. (1969) Quantitative phyletics and the evolution of anurans. Systematic Zoology, 18, 1-32.

Lanave, C., Preparata, G., Saccone, C. \& Serio, G. (1984) A new method for calculating evolutionary substitution rates. Journal of Molecular Evolution, 20, 86-93.

Lavrenchenko, L.A., Milishnikov, A.N., Aniskin, V.M., Warshavsky, A.A. \& Gebrekidan W. (1997) The genetic diversity of small mammals of the Bale Mountains, Ethopia. Ethiopian Journal of Science, 20(2), 213-233.

Lawrence, B. \& Loveridge, A. (1953) Zoological results of a fifth expedition to East Africa. I. Mammals from Nyasaland and Tete. With notes on the genus Otomys. Bulletin of the Museum of Comparative Zoology at Harvard College, 110, 1-80.

Lecompte, E., Aplin, K., Denys, C. Catzeflis, F., Chades, M. \& Chevret, P. (2008) Phylogeny and biogeography of African Murinae based on mitochondrial and nuclear gene sequences, with a new tribal classification of the subfamily. BMC Evolutionary Biology, 8:199 doi:10.1186/1471-2148-8-199.

Maddison, W.P. \& Maddison, D.R. (2000) McClade: analysis of phylogeny and character evolution, version 4.07. Sinauer Associates, Sunderland, MA, USA.

Marcus, L.F. (1990) Traditional morphometrics. In: Rohlf, F.J., Bookstein, F.L., (Eds.), Proceedings of the Michigan Morphometrics Workshop. The University of Michigan Museum of Zoology, Special Publication No. 2, Ann Arbor, 77-122.

Marcus, L.F. \& Corti, M. (1996) Overview of the new, or geometric morphometrics. In: Marcus, L.F., Corti, M., Loy, A., Naylor, G.J.P. \& Slice, D.E. (Eds.), Advances in morphometrics. Plenum Press, New York, pp. 1-13.

Maree, S. (2002) Phylogenetic relationships and mitochondrial DNA sequence evolution in the African rodent subfamily Otomyinae (Muridae). PHD Thesis. University of Pretoria, Pretoria.

Meester, J.A.J., Rautenbach, I.L., Dippenaar, N.J. \& Baker, C.M. (1986) Classification of Southern African mammals. Transvaal Museum Monograph, 5, 1-359.

Misonne, X. (1974) Part 6, Order Rodentia. In: Meester, J. \& Setzer, H.W. (Eds.), The mammals of Africa: an identification manual. Smithsonian Institution Press, Washington, D.C.

Moussalli, A. (2003) BIOCLIMav v1.0, user guide. Cooperative Research Centre for Tropical Rainforest Ecology and Management, Brisbane.

Musser, G.G. \& Carleton, M.D. (1993) Family Muridae. In: Wilson, D.E. \& Reeder, D.M. (Eds.), Mammal Species of the World: a taxonomic and geographic reference 2nd edition. Smithsonian Institution Press, Washington D.C., 501-755.

Musser, G.G. \& Carleton, M.D. (2005) Superfamily Muroidea. In: Wilson, D.E. \& Reeder, D.M. (Eds.), Mammal species of the world: a taxonomic and geographic reference $3^{\text {rd }}$ edition. John Hopkins University Press, Baltimore, 894-1531.

Nei, M. (1987) Molecular evolutionary genetics. Columbia University Press, New York, NY.

Osgood, W.H. (1910) Diagnoses of new East African mammals, including a new genus of Muridae. Field Museum of Natural History, Zoological Series, 10, 5-13.

Pääbo, S. \& Wilson, A.C. (1988) Polymerase chain reaction reveales cloning artefacts. Nature (London), 334, 387-388.

Partridge, T.C. (1973) Geomorphological dating of cave openings at Makapansgat, Sterkfontein, Swartkrans and Taung. Nature (Lond.), 246, 75-79.

Partridge, T.C., Wood, B.A. \& deMenocal P.B. (1995) The influence of global climate changes and regional uplift on largemammalian evolution in East and Southern Africa. In: Vrba, E.S. (Ed.), Paleoclimate and evolution with emphasis on human evolution. Yale University Press, New Haven, 331-356.

Petter, F. (1982) Les parentés des Otomys du Mont Oku (Cameroun) et des autres formes rapportées à O. irroratus (Brants, 1827) (Rodentia, Muridae). Bonner Zoologische Beiträge, 33, 215-222.

Pickford, M. (1990) Uplift of the Roof of Africa and its bearing on the evolution of Mankind. Human Evolution, 5, 1-20.

Pocock, T.N. (1976) Pliocene mammalian microfauna from Langebaanweg: a new fossil genus linking the Otomyinae with the Murinae. South African Journal of Science, 72, 58-60.

Pocock, T.N. (1987) Plio-Pleistocene fossil mammalian microfauna of Southern Africa. A preliminary report including descriptions of two new fossil muroid genera (Mammalia, Rodentia). Palaeontologia Africana, 26, 69-91.

Posada, D. (2006) ModelTest Server: a web-based tool for the statistical selection of models of nucleotide substitution online. Nucleic Acids Research, 34, W700-W703.

Posada, D. \& Crandall, K.A. (1998) MODELTEST: Testing the model of DNA substitution. Bioinformatics, 14, 817-818.

Posada, D. \& Crandall, K.A. (2001) Selecting the best-fit model of nucleotide substitution. Systematic Biology, 50, 580-601. 
Rambaut, A. \& Drummond, A.J. (2005) TRACER v1.2. MCMC Trace Analysis Tool. Available from http://beast.bio.ed.ac.uk (accessed 17 May 2011).

Rodriguez, F., Oliver, J.L., Marin, A. \& Medina, J.R. (1990) The general stochastic model of nucleotide substitution. Journal of Theoretical Biology, 142, 485-501.

Rohlf, F.J. (1997) NTSYS-pc, version 2.01h. Exeter Software, Setauket, New York.

Rohlf, F.J. (1998) On applications of geometric morphometrics to studies of ontogeny and phylogeny. Systematic Biology, 47, $147-158$.

Rohlf, F.J. (2002) Geometric morphometrics in phylogeny. In: Macleod, N \& Forey, P.L. (Eds.), Morphology, shape and phylogenetics. Systematic Association Special Volume Series 64. Francis \& Taylor, London, pp. 175-193.

Rohlf, F.J. (2007) tpsRegr version 1.35. State University of New York at Stony Brook.

Rohlf, F.J. (2005) tpsRelw version 1.42. State University of New York at Stony Brook.

Rohlf, F.J. (2006) tpsDig version 2.10. State University of New York at Stony Brook.

Rohlf, F.J. \& Corti, M. (2000) The use of two-block partial least squares to study covariation in shape. Systematic Biology, 49, $740-753$.

Rohlf, F.J. \& Marcus, L.F. (1993) A revolution in morphometrics. Trends in Ecology and Evolution, 8, 129-132.

Rohlf, F.J. \& Slice, D. (1990) Extensions of the Procrustes method for the optimal superimposition of landmarks. Systematic Zoology, 39, 40-59.

Rowe, K.C., Reno, M.L., Richmond, D.M., Adkins, R.M. \& Steppan, S.J. (2008) Pliocene colonization and adaptive radiations in Australia and New Guinea (Sahul): Multilocus systematics of the old endemic rodents (Muroidea: Murinae). Molecular Phylogenetics and Evolution, 47, 84-101.

Saiki, R.K., Gelfand, D.H., Stoffel, S., Scharf, S.J., Higuchi, R., Horn, G.T., Mullis, K.B. \& Erlich, H.A. (1988) Primer-directed enzymatic amplification of DNA with a thermostable DNA polymerase. Science, 239, 487-491.

Saitou, N. \& Nei, M. (1987) The neighbor-joining method: a new method for reconstructing phylogenetic trees. Molecular Biology and Evolution, 4, 406-425.

Sambrook, J. \& Maniatis, T. (1989) Molecular cloning: a laboratory manual. Cold Spring Harbor Laboratory, Cold Spring Harbor, New York, USA.

Sanger, F., Nicklen, S. \& Coulson, A.R. (1977) DNA sequencing with chain terminating inhibitors. Proceedings of the National Academy of Science USA, 74(12), 5463 - 5468.

Sénégas, F. (2001) Interpretation of the dental pattern of the South African fossil Euryotomys (Rodentia, Murinae) and origin of otomyine dental morphology. In: Denys, C., Granjon, L. \& Poulet, A (Eds.), African small mammals Paris: IRD, pp. 151160.

Sénégas, F. \& Avery, M. (1998) New evidence for the murine origins of the Otomyinae (Mammalia, Rodentia) and the age of Bolt's Farm (South Africa). South African Journal of Science, 94, 503-507.

Setzer, H.W. (1953) Four new mammals from the Anglo-Egyptian Sudan. Journal of the Washington Academy of Sciences, 43(10), 333-335.

Simmons, M.P. \& Ochoterena, H. (2000) Gaps as characters in sequence-based phylogenetic analyses. Systematic Biology, 49, 369-381.

Stanger-Hall, K. \& Cunningham, C.W. (1998) Support for a monophyletic Lemuriformes: overcoming incongruence between data partitions. Molecular Biology and Evolution, 15(11), 1572-1577.

Stanley, W.T. \& Hutterer, R. (2000) A new species of Myosorex Gray, 1832 (Mammalia: Soricidae) from the Eastern Arc mountains, Tanzania. Bonner Zoologische Beiträge, 49, 19-29.

Stanley, W.T. \& Olson, L.E. (2005) Phylogeny, phylogeography, and geographic variation of Sylvisorex howelli (Soricidae), an endemic shrew of the Eastern Arc Mountains, Tanzania. Journal of Zoology, London, 266, 341-354.

Stanley, W.T., Rogers, M.A. \& Hutterer, R. (2005) A new species of Congosorex from the Eastern Arc Mountains, Tanzania, with significant biogeographical implications. Journal of Zoology, London, 265, 269-280.

Stockman, A.K. \& Bond, J.E. (2007) Delimiting cohesion species: Extreme population structuring and the role of ecological interchangeability. Molecular Ecology, 16, 3374-3392.

Sullivan, J., Holsinger, K.E. \& Simon, C. (1995) Among-site rate variation and phylogenetic analysis of the 12S rRNA in Sigmodontine rodents. Molecular Biology and Evolution, 12, 988-1001.

Swofford, D.L. (2002) PAUP*. Phylogenetic analysis using parsimony (*and other methods), 4b10. Sunderland, Massachusetts: Sinauer Associates.

Taylor, P.J., Meester, J. \& Kearney, T. (1993) The taxonomic status of Saunder's vlei rat, Otomys saundersiae Roberts (Rodentia: Muridae: Otomyinae). Journal of African Zoology, 107, 571-596.

Taylor, P.J. \& Kumirai, A. (2001) Craniometric relationships between the southern African vlei rat, Otomys irroratus (Rodentia, Muridae, Otomyinae) and allied species from north of the Zambesi River. In: Denys, C., Granjon, L. \& Poulet, A. (Eds.), African small mammals, IRD, Paris, 161-181.

Taylor, P.J., Kumirai, A. \& Contrafatto, G. (2004a) Geometric morphometric analysis of adaptive cranial evolution in southern African laminate-toothed rats (Family: Muridae; Tribe: Otomyini). Durban Museum Novitates, 29, 110-122.

Taylor, P.J., Denys, C. \& Mukerjee, M. (2004b) Phylogeny of the African murid tribe Otomyini (Rodentia), based on morphological and allozyme evidence. Zoologica Scripta, 33, 389-402.

Taylor, P.J., Kumirai, A. \& Contrafatto, G. (2005) Species with fuzzy borders: the taxonomic status and species limits of Saun- 
ders' vlei rat, Otomys saundersiae Roberts (Rodentia: Muridae: Otomyini). Mammalia, 69, 297-322.

Taylor, P. J., Maree, S., van Sandwyk, J., Kerbis Peterhans, J.C., Stanley, W.T., Verheyen, E., Kaliba, P., Verheyen, W., Kaleme, P. \& Bennett, N.C. (2009a) Speciation mirrors geomorphology and palaeoclimatic history in African laminate-toothed rats (Muridae: Otomyini) of the Otomys denti and O. lacustris species-complexes in the "Montane Circle" of East Africa. Biological Journal of the Linnean Society, 96, 913-941.

Taylor, P. J., Maree, S., van Sandwyk, J., Baxter, R. \& Rambau, R.V. (2009b) When is a species not a species? Uncoupled phenotypic, karyotypic and genotypic divergence in two species of South African laminate-toothed rats (Murinae: Otomyini). Journal of Zoology (London), 277(4), 317-332.

Templeton, A.R. (1998) Species and speciation: Geography, population structure, ecology and gene trees. Pages 32-41 in Endless forms: Species and speciation (D. J. Howard and S. H. Berlocher, eds.). Oxford University Press, New York, New York.

Thomas, O. (1891) On a collection of small mammals made by Mr. F.J. Jackson in eastern Africa. Proceedings of the Zoological Society of London, 1891, 181-187.

Thomas, O. (1900) List of mammals obtained by Mr. H. J. Mackinder during his recent expedition to Mount Kenya, British East Africa. Proceedings of the Zoological Society of London, 1900, 173-180.

Thomas, O. (1902a) On a collection of mammals from Abyssinia, including some from Lake Tsana, collected by Mr. Edward Degen. Proceedings of the Zoological Society of London 1902, 308-316.

Thomas, O. (1902b) On some new forms of Otomys. Annals and Magazine of Natural History, series 7, 10, 311-314.

Thomas, O. (1906a) New mammals collected in north-east Africa by Mr. Zaphiro, and presented to the British Museum by W.N. McMillan. Annals and Magazine of Natural History, series 7, 18, 300-306.

Thomas, O. (1906b) Descriptions of new mammals from Mount Ruwenzori. Proceedings of the Zoological Society, London, 1906, 136-147.

Thomas, O. (1918) A revised classification of the Otomyinae, with descriptions of new genera and species. Annals and Magazine of Natural History, series, 9(2), 203-211.

Thompson, J.D., Gibson, T.J., Plewniak F., Jeanmougin, F. \& Higgins, D.G. (1997) The CLUSTAL X windows interface: flexible strategies for multiple sequence alignment aided by quality analysis tools. Nucleic Acids Research, 25, 4876-4882.

Van der Straeten, E. \& Kerbis Peterhans, J.C. (1999) Praomys degraaffi, a new species of Muridae from eastern Africa. South African Journal of Science, 34(2), 80-90.

Williams, P.L. \& Fitch, W.M. (1990) Phylogeny determination using the dynamically weighted parsimony method. Methods Enzymology, 183, 615-626.

Winkler, A.J. (2002) Neogene paleobiogeography and East African paleoenvironments: contributions from the Tugen Hills rodents and lagomorphs. Human Evolution, 42(1-2), 237-256.

Wroughton, R.C. (1906) Notes on the genus Otomys. Annals and Magazine of Natural History, series 7(18), 264-278.

Yalden, D.W., Largen, M.J. \& Kock, D. (1976) Catalogue of the mammals of Ethiopia. 2. Insectivora and Rodentia. Monitore Zoologico Italiano, Supplemento 8(1), 1-118.

Yalden, D.W., Largen, M.J., Kock, D. \& Hillman, J.C. (1996) Catalogue of the mammals of Ethiopia and Eritrea. 7. Revised checklist, zoogeography, and conservation. Tropical Zoology, 9, 73-164.

APPENDIX 1. Supplementary specimens of eastern African Otomys were broadly examined for morphological and morphometric comparisons with taxa traditionally classified under $O$. typus s.l. Those of $O$. tropicalis are listed as trinomials to convey their regional origin and historical usage, not (!) to endorse formal subspecific divisions. Voucher specimens that were used in the molecular analysis are indicated in bold face.

Otomys barbouri. UGANDA: Mount Elgon, Kuburomi (MCZ 31369 [holotype], 31371, 31422-31424, 31438); Mount Elgon, Mission Deloma (MNHN 1933.2758-1933.2760, 1933.2762-1933.2766); Mount Elgon, Mude Camp, 3600 m (DM 6262, 6263, 6275, 6280, 6281).

Otomys dollmani. KENYA: Mathews Range, Mount Gargues, 6,000 ft (1828.8 m) (USNM 181790 [holotype], 184041-184046).

Otomys lacustris. TANZANIA: Ufipa Plateau, Mbizi Forest (BMNH 58.355, 58.356, 58.358, RMCA 96037); Mbizi Mountains Forest Reserve, $0.5 \mathrm{~km} \mathrm{~S}$ and $3 \mathrm{~km}$ E Wipanga, $2300 \mathrm{~m}$ (FMNH 171302); Poroto Mountains, east of Mbeya (BMNH 58.363); Mount Rungwa Forest Reserve (FMNH 163761); Udzungwa Mountains, 4 km W and 5 km N Chita, $1460 \mathrm{~m}$ (FMNH 155623); Udzungwa Mountains, $19.5 \mathrm{~km} \mathrm{~N}$ and $0.5 \mathrm{~km} \mathrm{~W}$ [where?], $2000 \mathrm{~m}$ (FMNH 155461); Udzungwa Mountains, Iringa District Dabaga, 6,000 ft (1828.8 m) (MCZ 26654); Ukaguru Mountains, Mamiwa-Kisara Forest Reserve, 1 km E and 0.75 km S Mount Munyera, 1900 m (FMNH 166648, 166907-166909); Ukinga Mountains, Madehani, northeast end of Lake Nyasa, 7,000 ft (2133.6 m) (FMNH 44411; MCZ 26345-26348, 26352-26354, 26358 [holotype]). ZAMBIA: Lucheche River, Abercorn (MCZ 51146).

Otomys tropicalis elgonis. D.R. CONGO: S. Elgon (RMCA 5185, 5253) [???]. KENYA: 12 mi N Eldama Ravine, 8,800 ft (2682.24 m) (USNM 164281); Uasin Gishu Plateau, $30 \mathrm{mi}$ N Ravine, 8,600 ft (2621.28 m) (USNM 164286-164289); Uasin Gishu Plateau, Nzoia River, 6,000 ft (1828.8 m) (USNM 164282-164285); Kaimosi Forest (USNM 184003184017); Kakamega (MCZ 31375, 31416-31420, 31432-31437, 31439, 31440; USNM 184018); Molo (FMNH 16693, 
16695); Molo, Londiani Forest Camp, 2400 m (RMCA 38950, 38951); Mount Elgon, Coletatomoi (MCZ 31366); Mount Elgon National Park, 15 km from Chorlim Gate towards Koitobos Peak, bamboo zone (USNM 590004-590006, 590011); Junction camp at foot of Mount Elgon (RMCA 5249). UGANDA: Mount Elgon, Mission Delomo (MNHN1933.2763); Mount Elgon, Sipi (MCZ 31269-31272, 31373, 31374, 31377-31381, 31426-31432); Bumasola, Mt Elgon (DM 6282).

Otomys tropicalis faradjius. D.R. CONGO: Djugu, 1650 m (RMCA10714); Upper Uele District, Faradje (AMNH 50357 [holotype]; RMCA 12995); Mongbwalu, 1300 m (RMCA 15564); Parc Nacional Garambo (RMCA 7834-M167, 7834-M169, 7834-M173, 7834-M174, 7834-M176, 7834-M179, 7834-M187, 7834-M189, 7834-M191, 7834-M192, 7839-M165, 8934-M193).

Otomys tropicalis ghigii. UGANDA: Masaka, Bugala Island, Kalangala, 1180 m (FMNH 138125-138127).

Otomys tropicalis giloensis. SUDAN: "South" (SM 36564-36566); Imatong Mountains, Gilo (FMNH 179460; SM 2716327165, 27539, 27543, 27544, 27546, 27552, 27554, 27556, 27557, 27561, 27567, 27568, 27762); 5 mi S Gilo (FMNH 108207); Mount Kinyeti (SM 29985, 29986, 30186); Nagishot, Didinga (SM 29990, 29992, 29994).

Otomys tropicalis nubilus. KENYA: northeast of Mount Kenya, Jombeni Range, 6,000 ft (1228.8 m) (BMNH 11.12.2.4 [holotype]).

Otomys tropicalis rubeculus. UGANDA: Gitebe (MNHN 1960.459); Kagambah, 1600 m (BMNH 11.12.3.87); Kampala (MNHN 1985.199).

Otomys tropicalis tropicalis. KENYA: Aberdare Mountains (BMNH 10.5.3.46-10.5.3.48, 10.5.3.52, 10.5.3.54, 10.5.3.56), $10,500 \mathrm{ft}$ (3200.4 m) (USNM 164279, 164280); Aberdare Mountains, summit, 11,000 ft (3352.8 m) (USNM 184024184032, 184037-184340); Aberdare Mountains, moorland (RMCA a1.008-M-1125 (R28216), a1.008-M-1126 (R28217), a1.008-M-1128 (R28222), a1.008-M-1130 (28234)); Aberdare Mountains, Changongorra, 7,000 ft (2133.6 m) (USNM 184019-184023); Aberdare National Park, Fishing Lodge, 8,760, 9,000, and 9,500 ft (2670.048,2743.2, and 2895.6 m) (USNM 589998, 589999, 590002, 590003, 590012-590015); Aberdare Range, Mount Kinangop, 2700 m (MNHN 1913.216a); Aberdares, Ruhuruini (a1.008-M-1122 (R 28198)); Mount Kenya (RMCA 5031; R 28138; USNM 165324, 165326, 165327, 165335), west slope, 7,000-13,700 ft (2133.6-4175.76 m)(AMNH 80992; BMNH 0.2.1.20 [holotype]; CM 2836, 2837; FMNH 43819-43822; USNM 164277, 164291-164293, 164296, 164298, 164299, 164307, 164309164312, 164314-164324, 164326, 164330, 164331, 164337-164343, 164347-164350, 164353, 164354, 164356, 164359164363, 164365-164373, 164375), 4000 m (MNHN 1913.215a); Mount Kenya, Naro Moru, 10,000 ft (USNM 590000, 590001); Mount Kenya, Naro Moru Gate, Meteorological Station, 10,000 ft (3048 m) (USNM 590007-590010); Mount Kenya, Meteorological Station (R 28369, 28380, 28385, 28388, 28394, 28398); Mount Kenya, Solai (BMNH 11.4.7.37, 11.12.8.40, 11.12.8.43); Kangaita, 6 mi N Kerugoy (MNHN 1961.24-1961.27); Naivasha Plains, Nalsitichu River (USNM 184036); 10 mi E Nyeri (USNM 164278); Ololua (R 28117); Thompson Falls Forest (SM 23887).

Otomys tropicalis vivax. KENYA: Mount Nyiru, south of Lake Rudolph (BMNH 12.7.1.425 [holotype]).

Otomys tropicalis vulcanis. BURUNDI: Ntentamaza (MNHN 1993.2332-1993.2337, 1993.2340-1993.2345); Tora (MNHN 1993.2147, 1993.2151, 1993.2300-1993.2321, 1993.2322a, 1993.2322b, 1993.2323-1993.2331, 1993.2338-1993.2340, 1993.2346-1993.2352). D.R. CONGO: Astrida (RMCA 20173, 20494, 20567, 21211, 21219, 27623); Beni (RMCA 16354, 16355); Blukwa (RMCA 9598, 9601, 12824); Bukavo (RMCA 82001-M1-82001-M3); Sud Kivu, Fomilac (USNM 535913); Gala (RMCA 8024); Gitebe (RMCA 82011-M872, 82011-M912); Kabara (RMCA 82011-M916); Kaberanyuma (RMCA 82011-M877); Kabira (RMCA 30421); Sud Kivu, Kahungu (USNM 535910, 535911); Kahuzi (RMCA 30418); Kalindera Masereka (RMCA 82011-M917); Kambekla (Butembo), 1800 m (RMCA 74024-M3, 74024-M4); Kasali (RMCA 82011-M879); Sud Kivu, Kayandja (USNM 535912); Kundhuru (RMCA 16689); Lake Ganda (RMCA 16690, 16692); Sud Kivu, Bogamanda, Lemera (USNM 535907); Sud Kivu, Lushala (USNM 535914); Lushebere (RMCA 30423); Lwege (RMCA 30411); Lwiro (RMCA 32454); Magera, 2000 m (RMCA 82011-M885); Sud Kivu, Bukuvu, Mugaba, 2300 m (USNM 375509-375513, 498739); Musai, 20 km S Butembo (RMCA 13146, 13147); Mutsora, 1200 m (RMCA 82011-M891); Muvo (RMCA 82011-M893); Nyambasha (RMCA 30413); Nyamirwa (RMCA 21847); Nyamlagira (RMCA 82011-M896, 82011-M923); Nyragongo (RMCA 82011-M905). Rukumi, 3500 m (RMCA 82011M926, 82011-M927, 82011-M929-82011-M931); Rumangaba, 1600 m (RMCA 82011-M932, 82011-M933); Rutshuru (RMCA 15208, 17029, 17030, 82011-M934, 82011-M935); Rwindi (RMCA 82011-M908, 82011-M938); Albert National Park, northern Virungas, Tshamugussa, 2250 m (RMCA 82011-M939-82011-M941, 82011-M943 , 82011-M944); Tusi Tsiaberimu (RMCA 82011-M945); Winka, near station (RMCA 32810); locality unknown (RMCA 33450). RWANDA: Butare INRS (RMCA 74020-M1062); Gaminga (RMCA 82011-M867); Gasarenda (RMCA 74020-M616, 74020-M617, 74020-M621, 74020-M624, 74020-M626); Gitesi (RMCA 74020-M630); Kagano [Kataka] (RMCA 74020-M1065); Kibuye (RMCA 74020-M1074); Kigombe (RMCA 74020-M684); Mamba (RMCA 74020-M498, 74020-M499, 74020M992); Masaka (RMCA 74020-M645); Mukanda (RMCA 5023); Murene (RMCA 74020-M651); Musi Milsi (RMCA 74020-M618); Mutura (RMCA 74020-M679); Nkuli (RMCA 74020-M685); Nyamikenke (RMCA 74020-M635); Nyarubuye (RMCA 74020-M680); Rwanda (RMCA 74020-M1078); Uinka, Cyangugu (USNM 340922, 340923). UGANDA: Ruwenzori (MNHN 1911.734). 
APPENDIX 2. Information of voucher specimens included in the molecular phylogenetic analysis. Latitude (Lat.) and longitude (Long.) are provided in decimal degrees format. The asterisk $(*)$ indicate vouchers of which 12S rRNA were sequenced.

\begin{tabular}{llllll}
\hline Species \& Geographic Origin & $\begin{array}{l}\text { Lat. \& } \\
\text { Long. }\end{array}$ & Collector & $\begin{array}{l}\text { Museum numbers } \\
\text { (field number) }\end{array}$ & $\begin{array}{l}\text { Genbank } \\
\text { Accession } \\
\text { numbers }\end{array}$ & $\begin{array}{l}\text { Genbank } \\
\text { Accession } \\
\text { numbers } \\
\text { (cyt } b)\end{array}$ \\
& & & $(12 S$ rRNA)
\end{tabular}

O. typus s.s.

Mt Guna, Ethiopia

$11.71 \mathrm{~N}$

L. Lavrenchenko

ZMMU 172732

JF796016

$38.25 \mathrm{E}$

(1110)

O. fortior

Beletta Forest, Jimma, Ethiopia, $1750 \mathrm{~m}$

$7.53 \mathrm{~N}$

36.55E

Beletta Forest, Ethiopia

Inegwa Forest, $20 \mathrm{~km} \mathrm{~N}$ of Tepi,

Ethiopia, $2340 \mathrm{~m}$

L. Lavrenchenko

ZMMU 164962*(47) JF796010

ZMMU 166072 (798) JF796011

L. Lavrenchenko

ZMMU 181666

JF796012

(1625)

ZMMU 181667

(1629)

JF796013

O. helleri sp. nov. (= "Sp. B”)

Bale Mts, Ethiopia

$7.10 \mathrm{~N}$

39.77E

L. Lavrenchenko

ZMMU 162597 (232) JF796014

ZMMU 162600 (338) JF796015

O. simiensis sp. nov. (= "Sp. D")

Sankaber, Simien Mts, Ethiopia, $3250 \mathrm{~m}$

$13.23 \mathrm{~N}$

$38.05 \mathrm{E}$

$-0.47 \mathrm{~S}$

36.73E

O. tropicalis

Aberdares, moorland, Kenya

$-0.32 \mathrm{~S}$

$36.70 \mathrm{E}$

Kenya, 9,500 ft (2900 m)

Ruhuruini, Aberdares Mts, Kenya

$-0.42 \mathrm{~S}$

$36.63 \mathrm{E}$

O. tropicalis s.s.

Mt Kenya KWS NM Gate, Kenya $\quad-0.17 \mathrm{~S}$

$37.15 \mathrm{E}$

Mt Kenya, Naro Moru, Kenya, $10,000 \mathrm{ft}(3050 \mathrm{~m})$

$-0.18 \mathrm{~S}$

$37.17 \mathrm{E}$

L. J. McLellan

W. N. Verheyen $\dagger$

W. N. Verheyen $\dagger$

RMCA a1.008-M-

1125 (R28216)

RMCA a1.008-M- JF796004

1126 (R28217)

RMCA al.008-M

1128 (R28222)

USNM 590002*

USNM 590003*

RMCA al.008-M-

1122 (R28198)

W. N. Verheyen $\dagger$

RMCA a1.008-M-

1138 (R28423)

RMCA a1.008-M- JF796006

1133 (R28380)

RMCA a1.008-M-

1136 (R28394)

O. tropicalis "elgonis"

Mt Elgon, 15km from Chorlim

Gate, bamboo zone

$1.15 \mathrm{~N}$

$34.58 \mathrm{E}$

L. J. McLellan

USNM 590000*

JF795994

JF795995

JF796003

JF795973

JF795974

JF796001

JF796007

JF795976

USNM 590004*

JF795996

JF795977

USNM 590005*

JF795997

JF795970

USNM 590006*

JF795998

JF795978

DM 6282*

JF795969

P. J. Taylor

JF795999 
APPENDIX 2. (continued)

Species \& Geographic Origin

Lat. \& Collector

Museum numbers

Genbank

Genbank

Long.

(field number)

Accession

Accession

numbers

numbers

(cyt $b$ )

(12S rRNA)

O. tropicalis faradjius

Rethy, DRC

$2.09 \mathrm{~N}$

A. Laudisoit

RMCA a6.016-M-

JF796000

30.89E

2034 (CA614)

O. dartmouthi

Kibira NP, Ndora Zone, Giseram,

$-2.85 \mathrm{~S}$

$29.40 \mathrm{E}$

J. C. Kerbis-Peter-

FMNH149007

JF795985

Burundi, 1950m

hans

Bujuju River, Ruwenzori Mts, Kas-

ese Dist., DRC, 11,050 ft (3370m)

$0.36 \mathrm{~N}$

J. C. Kerbis-Peter-

FMNH 144327*

JF795986-

JF795975

29.96E hans

O. zinki

Mt Kilimanjaro NP, $7 \mathrm{~km} \mathrm{~N}, 2.5 \mathrm{~km}$

W Maua, Tanzania, 2477m

$-3.21 \mathrm{~S}$

W. T. Stanley

FMNH 174174*

JF795989

JF795972

Mt Kilimanjaro East, Maundi Cra-

$-3.07 \mathrm{~S}$

ter grassland, Tanzania, $3270 \mathrm{~m} \quad 37.50 \mathrm{E}$

W. N. Verheyen $\dagger$

RMCA 96.037-M- JF795987

6801 (CTZ1764)

RMCA 96.037-M- JF795988

6805 (CTZ1902)

O. orestes

Aberdares National Park Fishing $\quad-0.31 \mathrm{~S}$

lodge, 9,000-9,500 ft (2743-2895 m) 36.70E

Aberdares, moorland, Kenya

$-0.46 \mathrm{~S}$

$36.73 \mathrm{E}$

L. J. McLellan

USNM $589997 *$

JF795990

JF795979

W. N. Verheyen $\dagger$

RMCA a1.008-M-

JF795991

1123 (R28205)

O. jacksoni

Mude Cave Camp, Mt Elgon,

$3600 \mathrm{~m}$

$1.16 \mathrm{~N}$

P. J. Taylor

DM $6261^{*}$

JF795992

JF795971

O. barbouri

Mude Cave Camp, Mt Elgon, $3600 \mathrm{~m}$

$1.16 \mathrm{~N}$

P. J. Taylor

DM 6263*

JF795980

JF795964

O. lacustris

Chingombe, Ufipa Plateau, Tanza-

$-7.87 \mathrm{~S}$

$31.66 \mathrm{E}$

nia, $1500 \mathrm{~m}$

$-7.10 \mathrm{~S}$

Udzungwa Mts, Chita, Tanzania,

$1460 \mathrm{~m}$

$37.64 \mathrm{E}$

W. N. Verheyen $\dagger$

RMCA 96.037-M-

EU874446

JF795965

5237 (R13272) *

W. T. Stanley

FMNH 155623*

EU874447

JF795966

O. sungae

Usambara Mts, Kidunda Forest,

$-4.97 \mathrm{~S}$

A. Laudisoit

RMCA a6.013-M-

FJ795993

Tanzania, $2047 \mathrm{~m}$

38.44E

2031(TE5012)

O. denti

Saddle between Mgahinga \&

$01,38 \mathrm{~S}$

J. C. Kerbis-Peter-

FMNH 157807*

EU874435

JF795959

$29,63 \mathrm{E}$ hans

Muhavura Mts, Mga
NP, Uganda, 2980m

Otomys species novo

Chilinda Camp Dam, Nyika NP,

$10.59 \mathrm{~S}$

J. C. Kerbis-Peter-

FMNH 191809*

EU874438

FJ795967

Nyika Plateau, Malawi, 2230m

33.71E hans

Parotomys brantsi

Kleinsee, Northern Cape Province, 29.68S

South Africa

C. H. Scholtz

TM 46133*

FJ19561

JF795962 
APPENDIX 2. (continued)

Species \& Geographic Origin

Lat. \& Collector

Museum numbers

Genbank

Genbank

Long.

(field number)

Accession

Accession

numbers numbers (cyt $b$ ) (12S rRNA)

O. angoniensis

Mkuze NR, KwaZulu Natal, South 27.63S

A. Berruti

DM 1983

Genbank

JF795961

Africa

$32.23 \mathrm{E}$

O. irroratus

Cedarberg, Northern Cape Province, South Africa

$32.43 \mathrm{~S}$

P. J. Taylor

DM 4317*

FJ19546

JF795960

O. occidentalis

Mt. Oku, Cameroun

$06.25 \mathrm{~N}$

C. Denys

CAM 207

FJ795981

$19.43 \mathrm{E}$

Mt. Oku, Cameroun

$06.25 \mathrm{~N}$

F. Lamotte

MNHN 710*

JF795963

$19.43 \mathrm{E}$

O. burtoni

Mt. Cameroun, Cameroun

$04.23 \mathrm{~N} \quad$ W. N. Verheyen $\dagger$

ZMFK 69-214-X

JF796009

$9.17 \mathrm{E}$

\section{OUTGROUPS}

Arvicanthis somalicus

Micaelamys namaquensis

Itala NR, KwaZulu Natal, South

$28.51 \mathrm{~S}$

L. Granjon

V.V.95.64

AF004574

AF141262

AF141215

Africa

$31.03 \mathrm{E}$

Aethomys sp.

Lemniscomys striatus

Oenomys hypoxanthus

Mus musculus

Rattus norvegicus

Batomys granti

AF004587

AF141211

AF141271

EU349769

V00711

V00711

X14848

AY324459

Phloeomys sp.

EU349775 